ORNL/TM-2000/289

ES-5048

\title{
ECOLOGICAL RISK ASSESSMENT FRAMEWORK FOR LOW- ALTITUDE OVERFLIGHTS BY FIXED-WING AND ROTARY-WING MILITARY AIRCRAFT *
}

Rebecca A. Efroymson

Environmental Sciences Divison

Oak Ridge National Laboratory

P. O. Box 2008

Oak Ridge, TN 37831

Winifred Hodge Rose

Sarah Nemeth

U. S. Army Construction Engineering Research Laboratory

Glenn W. Suter II

U. S. Environmental Protection Agency

* Research sponsored by the Strategic Environmental Research and Development Program of the U. S. Department of Defense under Interagency Agreement 2107-N218-S1 under contract DE-AC05-00OR22725 with UT-Battelle, LLC. Publication No. 5010, Environmental Sciences Division, ORNL. 
CONTENTS

Page

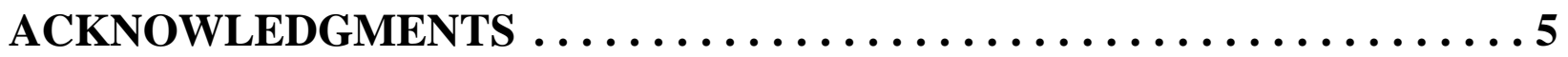

1. INTRODUCTION $\ldots \ldots \ldots \ldots \ldots \ldots \ldots \ldots \ldots \ldots \ldots \ldots \ldots \ldots \ldots \ldots \ldots \ldots$

2. PROBLEM FORMULATION FOR OVERFLIGHTS ............9 2.1 CHARACTERIZATION OF LOW-ALTITUDE AIRCRAFT OVERFLIGHTS

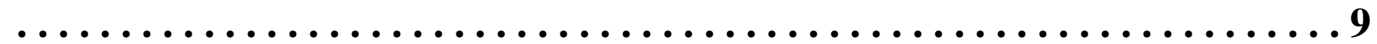

2.1.1 Definition of Low-altitude, Military Aircraft Overflights ..........9

2.1.1.1 Military mission functions ......................9

2.1.1.2 Relevant characteristics of overflights ..............9

2.1.1.3 Operational constraints and guidelines ............. 10

2.1.1.4 Types of aircraft ...........................11

2.1.1.5 Take-off and landing areas $\ldots \ldots \ldots \ldots \ldots \ldots \ldots \ldots \ldots \ldots 11$

2.1.1.6 Environmental contexts ......................11

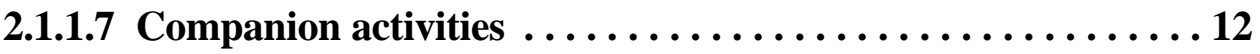

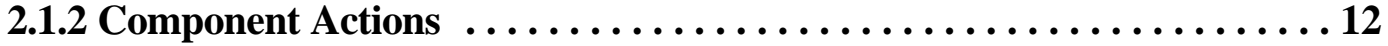

2.1.3 Definition of the Stressors and Modes of Action of Overflights $\ldots . \ldots 13$

2.2 ENDPOINT SELECTION FOR OVERFLIGHTS $\ldots \ldots \ldots \ldots \ldots \ldots \ldots \ldots \ldots$

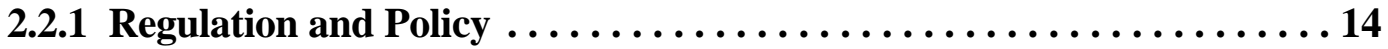

2.2.2 Properties that Increase Exposure to Stressors $\ldots \ldots \ldots \ldots \ldots \ldots \ldots 15$

2.2.3 Properties that Increase Sensitivity to Stressors $\ldots \ldots \ldots \ldots \ldots \ldots 16$

2.2.4 Criteria for Susceptibility $\ldots \ldots \ldots \ldots \ldots \ldots \ldots \ldots \ldots \ldots \ldots \ldots \ldots$

2.2.5 Generic Assessment Endpoints for Overflights ............ 18

2.3 DEFINITION OF SPATIAL AND TEMPORAL EXTENT $\ldots \ldots \ldots \ldots \ldots 20$

2.4 ACTIVITY-SPECIFIC CONCEPTUAL MODEL: GENERIC $\ldots \ldots \ldots \ldots \ldots 22$

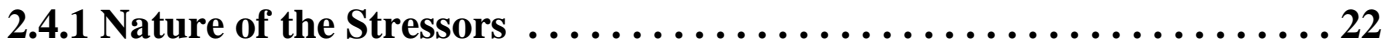

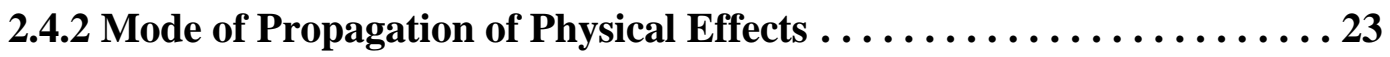

2.4.3 Mechanisms of Direct Physical Effects $\ldots \ldots \ldots \ldots \ldots \ldots \ldots \ldots . \ldots 24$

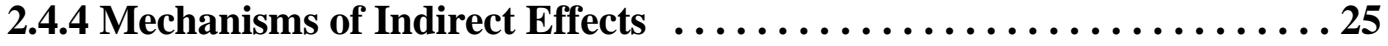

2.4.5 Generic Conceptual Model ........................ 25

2.5 ACTIVITY-SPECIFIC MEASURES OF EXPOSURE $\ldots \ldots \ldots \ldots \ldots \ldots \ldots 26$

2.6 ACTIVITY-SPECIFIC MEASURES OF EFFECTS $\ldots \ldots \ldots \ldots \ldots \ldots \ldots . \ldots . \ldots$

3. CHARACTERIZATION OF EXPOSURE $\ldots \ldots \ldots \ldots \ldots \ldots \ldots \ldots \ldots$

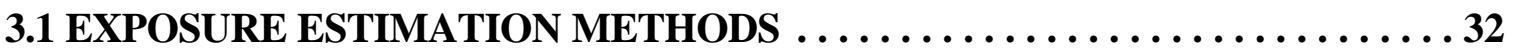

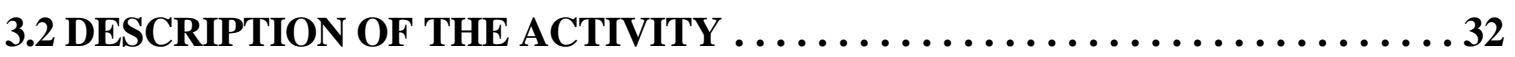

3.3 MEASUREMENTS TO DETERMINE EXPOSURE AT INSTALLATIONS 


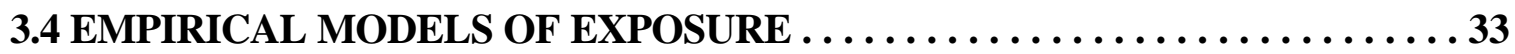

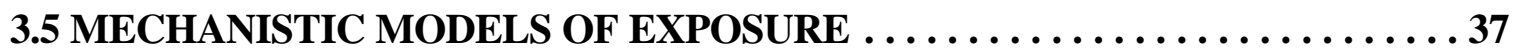

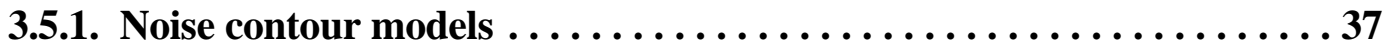

3.5.2 Habitat Models .................................39

3.5.3 Bird Strike Models .............................. 39

3.5.4 Air Movement Associated with Takeoffs and Landings $\ldots \ldots \ldots \ldots 40$

3.6 RECOMMENDATIONS FOR EXPOSURE ANALYSIS $\ldots \ldots \ldots \ldots \ldots \ldots 41$

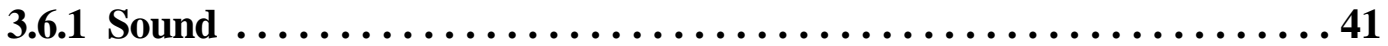

3.6.2 Visual Image of Aircraft $\ldots \ldots \ldots \ldots \ldots \ldots \ldots \ldots \ldots \ldots \ldots \ldots . \ldots \ldots 2$

3.6.3 Sound and Visual Image of Aircraft, Combined $\ldots \ldots \ldots \ldots \ldots \ldots 43$

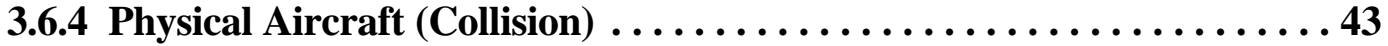

3.6.5 Air Movement Associated with Aircraft Takeoffs and Landings .... 43

3.6.6 Scorching of Vegetation $\ldots \ldots \ldots \ldots \ldots \ldots \ldots \ldots \ldots \ldots \ldots \ldots . \ldots \ldots$

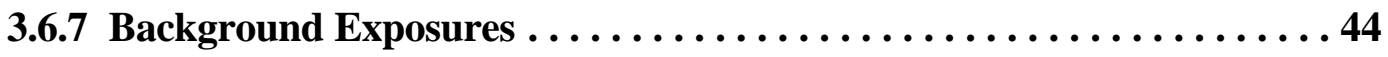

4. CHARACTERIZATION OF EFFECTS $\ldots \ldots \ldots \ldots \ldots \ldots \ldots \ldots \ldots$

4.1 CHOOSE EFFECTS MODELS $\ldots \ldots \ldots \ldots \ldots \ldots \ldots \ldots \ldots \ldots \ldots \ldots, \ldots \ldots \ldots$

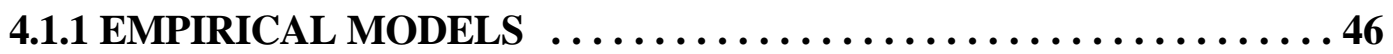

4.1.2 Mechanistic Models $\ldots \ldots \ldots \ldots \ldots \ldots \ldots \ldots \ldots \ldots \ldots \ldots \ldots \ldots$

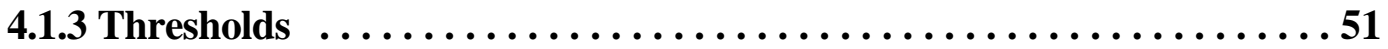

4.1.3.1 Raptors ...............................52

4.1.3.2 Waterfowl .............................52

4.1.3.3 Birds susceptible to bird strikes $\ldots \ldots \ldots \ldots \ldots \ldots \ldots \ldots . \ldots \ldots 3$

4.1.3.4 Ungulates ..............................53

4.1.3.5 Small mammals ...........................53

4.1.3.6 Reptiles ................................53

4.1.3.7 Amphibians ..............................53

4.1.3.8 Pinnipeds . . . . . . . . . . . . . . . . . . . . . . . 53

4.1.3.9 Cetaceans (whales, dolphins) and Sirenians (manatees) .....554

4.1.3.10 Productivity losses due to soil erosion ............. 54

4.1.3.11 Productivity losses due to air movement from takeoffs and

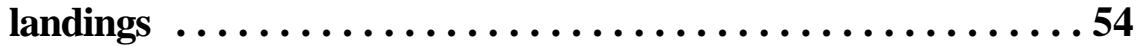

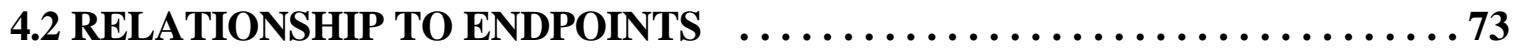

4.3 EFFECTS PROFILES: RECOMMENDATIONS FOR EFFECTS ANALYSIS

........................................

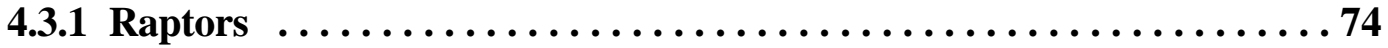

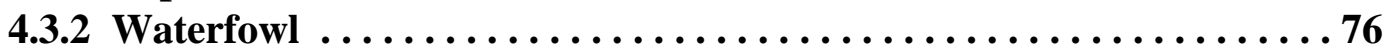

4.3.3 Birds Susceptible to Bird Strikes $\ldots \ldots \ldots \ldots \ldots \ldots \ldots \ldots \ldots \ldots \ldots$

4.3.4 Ungulates.$\ldots \ldots \ldots \ldots \ldots \ldots \ldots \ldots \ldots \ldots \ldots \ldots \ldots \ldots \ldots \ldots \ldots \ldots$

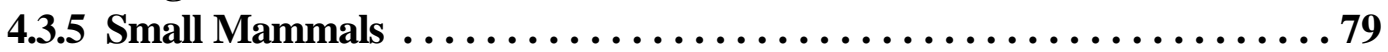

4.3.6 Reptiles ....................................80

4.3.7 Amphibians $\ldots \ldots \ldots \ldots \ldots \ldots \ldots \ldots \ldots \ldots \ldots \ldots \ldots \ldots \ldots \ldots \ldots$. $80 \ldots \ldots$

4.3.8 Pinnipeds $\ldots \ldots \ldots \ldots \ldots \ldots \ldots \ldots \ldots \ldots \ldots \ldots \ldots \ldots \ldots \ldots \ldots$. 
4.3.9 Cetaceans and Sirenians $\ldots \ldots \ldots \ldots \ldots \ldots \ldots \ldots \ldots \ldots \ldots \ldots . \ldots . \ldots . \ldots 1$

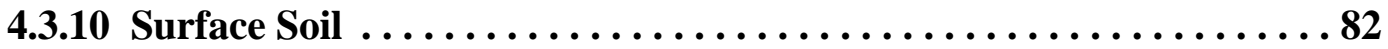

4.3.11 Plant Community $\ldots \ldots \ldots \ldots \ldots \ldots \ldots \ldots \ldots \ldots \ldots \ldots \ldots$

5. INTERMEDIATE RISK CHARACTERIZATION . . . . . . . . 83

6. ACTIVITY-SPECIFIC RISK CHARACTERIZATION . . . . . . . . . 84

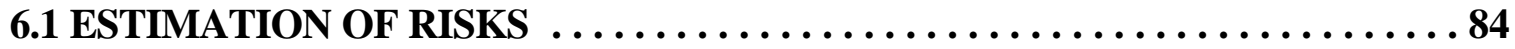

6.1.1 Implementing Exposure-Response Models $\ldots \ldots \ldots \ldots \ldots \ldots \ldots . \ldots 84$

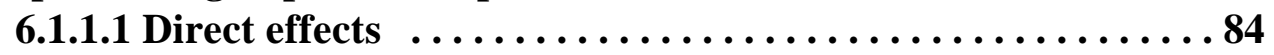

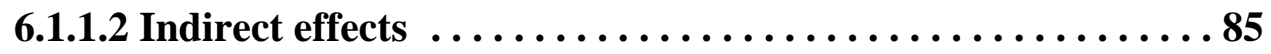

6.1.2 Weight of Evidence $\ldots \ldots \ldots \ldots \ldots \ldots \ldots \ldots \ldots \ldots \ldots \ldots \ldots \ldots \ldots$

6.1.3 Multiple Stressors and Activities $\ldots \ldots \ldots \ldots \ldots \ldots \ldots \ldots \ldots \ldots . \ldots 88$

6.1.3.1 Multiple modes of action of a single stressor ..........88

6.1.3.2 Multiple stressors ..........................88

6.1.3.3 Multiple, co-occurring activities ................88

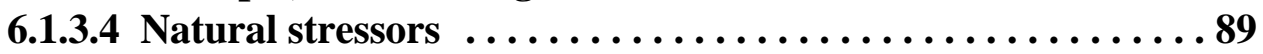

6.2 ESTIMATE UNCERTAINTY AND VARIABILITY $\ldots \ldots \ldots \ldots \ldots \ldots \ldots . \ldots 9$

6.2.1 Uncertainties in Estimates of Exposure $\ldots \ldots \ldots \ldots \ldots \ldots \ldots \ldots$

6.2.2 Uncertainties in Exposure-response Models ...............91

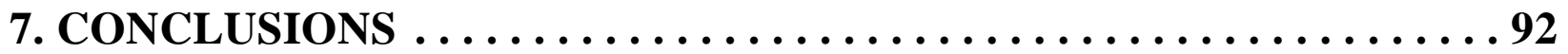

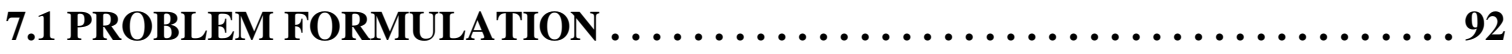

7.2 CHARACTERIZATION OF EXPOSURE $\ldots \ldots \ldots \ldots \ldots \ldots \ldots \ldots \ldots \ldots . \ldots 2$

7.3 CHARACTERIZATION OF EFFECTS $\ldots \ldots \ldots \ldots \ldots \ldots \ldots \ldots \ldots \ldots . \ldots . \ldots . \ldots 2$

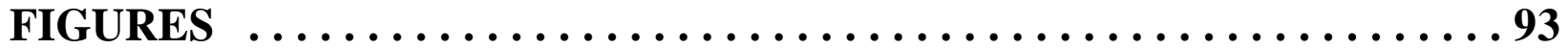

REFERENCES $\ldots \ldots \ldots \ldots \ldots \ldots \ldots \ldots \ldots \ldots \ldots \ldots \ldots \ldots \ldots$

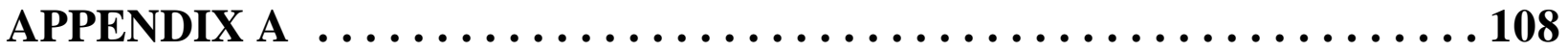




\section{ACKNOWLEDGMENTS}

This research has been funded by the U. S. Department of Defense Strategic Research and Development Program project CS-1054, A Risk Assessment Framework for Natural Resources on Military Training and Testing Lands.

We would like to acknowledge the following additional members of the project team who provided extensive comments on this report:

Keturah A. Reinbold, U. S. Army Construction Engineering Research Laboratory

Manroop Chawla, U. S. Army Construction Engineering Research Laboratory

Daniel S. Jones, Environmental Sciences Division, Oak Ridge National Laboratory

Bradley E. Sample, Environmental Sciences Division, Oak Ridge National Laboratory

Selena Mellon of Haverford College collected a large fraction of the references while she was a summer intern at Oak Ridge National Laboratory.

We would like to acknowledge the advisory committee of military conservation and training personnel that was created for this project and who directed us to develop a risk assessment framework for low-altitude aircraft overflights. Many have provided useful review comments.

Colonel Fred Pease, HQ U.S. Air Force; Directorate of Operations and Training; Chief, Airspace and Range Division

Peter Boice, Department of Defense, Office of the Deputy Under Secretary of Defense for Environmental Security

Larry Chenkin, U.S. Army Training Support Center

Desiree Di Mauro, U.S. Coast Guard HQ, Environmental Management Division

Ron Dow (former member), Naval Air Weapons Station; Point Mugu, CA; Head, Environmental Division

Melvin Jackson, Office of the Under Secretary of Defense (A\&T)/DTSE\&E/RR

Major W. Steven Huff, (Retired) U.S. Army, Defense Special Weapons Agency

Paul Thies, U.S. Army Environmental Center; Environmental Quality Division; Chief, Conservation Branch

Kim Michaels, U.S. Army Environmental Center, Environmental Quality Division, Conservation Branch

Randall Wentsel, USEPA

Lewis Shotten, Office of the Assistant Secretary of the Navy (Installations and Environment)

Kurt Riegel, Office of the Assistant Secretary of the Navy (Installations and Environment)

William van der Schalie, USEPA, National Center for Environmental Assessment

Valerie Morrill, U.S. Army Yuma Proving Ground, AZ; Command Technology Directorate; Conservation Manager, Environmental Sciences Division

Roger Dahlman, U.S. Department of Energy, DOE Representative to Conservation WG

Richard Kasul, U.S. Army Engineer Research and Development Center, Environmental Laboratory, Natural Resources Division, Resource Analysis Branch

CW05 Gary Matthews, Marine Corps Combat Development Command, Training and Education Support Branch, Range Management Support Officer

David Mouat, Desert Research Institute, Quaternary Sciences Center

James Omans, HQ U.S. Marine Corps; Head, Natural Resources Section

V. Frank Stone, Office of the Chief of Naval Operations

Christine Crabill, Institute for Defense Analyses

Susan Barrow, Nellis AFB, NV; Chief, Environmental Outreach and Programs Division

Thomas Heffernan, Eglin AFB, FL, Air Armament Center, 46th Test Wing/XPE, Range Environmental

Planning Office 
We also would like to thank the following researchers for providing reports, references and/or data for this report. It should not be assumed that they agree with all recommendations or other contents of this report:

Ann E. Bowles, Hubbs-Sea World Research Institute

Glenn Cada, Environmental Sciences Division, Oak Ridge National Laboratory

Christopher W. Clark, Bioacoustics Research Program, Cornell University

Virginia Dale, Environmental Sciences Division, Oak Ridge National Laboratory

Gerry Eddlemon, Environmental Sciences Division, Oak Ridge National Laboratory

Tom Fetherston, Naval Undersea Warfare Center

John Fittipaldi, Army Environmental Policy Institute

M. Blake Henke, Center for Conservation Research \& Technology

Anthony Krzysik, U. S. Army Construction Engineering Research Laboratory

Robert Kull, Geomarine Inc., formerly Air Force Center for Environmental Excellence, Brooks Air Force

Base

Robert McKinley, Noise Effects Branch, Wright-Patterson Air Force Base

Larry Pater, U. S. Army Construction Engineering Research Laboratory

W. John Richardson, LGL Limited, Environmental Research Associates

Daniel Roby, Oregon State University Cooperative Fish \& Wildlife Research Unit

William A. Russell, Jr., Environmental Noise Program, U.S. Army Center for Health Promotion \&

Preventive Medicine, Aberdeen Proving Ground

Catherine Stewart, Environmental Noise Program, U.S. Army Center for Health Promotion \&

Preventive Medicine, Aberdeen Proving Ground

David Ward, U. S. Geological Survey, Biological Resources Division, Alaska Science Center

Robert Washington-Allen, Environmental Sciences Division, Oak Ridge National Laboratory

Warren Webb, Environmental Sciences Division, Oak Ridge National Laboratory 


\section{INTRODUCTION}

This is a companion report to the risk assessment framework proposed by Suter et al. (1998): $A$ Framework for Assessment of Risks of Military Training and Testing to Natural Resources, hereafter referred to as the "generic framework." The generic framework is an ecological risk assessment methodology for use in environmental assessments on Department of Defense (DoD) installations. In the generic framework, the ecological risk assessment framework of the U. S. Environmental Protection Agency (EPA 1998) is modified for use in the context of 1) multiple and diverse stressors and activities at a military installation and 2) risks resulting from causal chains, e.g., effects on habitat that indirectly impact wildlife. Both modifications are important if the EPA framework is to be used on military installations.

In order for the generic risk assessment framework to be useful to DoD environmental staff and contractors, the framework must be applied to specific training and testing activities. Three activity-specific ecological risk assessment frameworks have been written 1) to aid environmental staff in conducting risk assessments that involve these activities and 2) to guide staff in the development of analogous frameworks for other DoD activities. The three activities are: 1) low-altitude overflights by fixed-wing and rotary-wing aircraft (this volume), 2) firing at targets on land, and 3) ocean explosions. The activities were selected as priority training and testing activities by the advisory committee for this project.

Ecological risk assessments for low-altitude overflights may be performed to fulfill NEPA requirements. Any change to operations at an Armed Services base, range, Military Training Route MTR) or Military Operations Area (MOA) requires the relevant service to evaluate environmental impacts, as defined in the National Environmental Policy Act (NEPA). Site managers may also use risk assessment to choose between two alternate overflight routes or two different MOAs at which to conduct a training exercise. Cumulative impacts associated with multiple training and testing activities may be estimated. In addition, the military services are expected to comply with legislation such as the Endangered Species Act or the Marine Mammal Protection Act. The former legislation requires that certain populations of plants and wildlife be protected, and the latter requires that certain actions be performed to minimize exposure if permits to "take" or harass marine mammals are given. Legislation may require that risks to metapopulations at multiple installations in a region be estimated.

Ecological risk assessment methods have the following advantages over other assessment methods:

- $\quad$ rigorous, quantitative models and measurements;

- $\quad$ focus on well-defined, susceptible, valued ecological receptors;

- $\quad$ emphasis on the planning process to satisfy training and conservation needs;

- $\quad$ reduction of overflights to component stressors (such as sound) to facilitate adding the effects associated with numerous training activities; and

- $\quad$ congruence with EPA policy.

The format of this report is the sequence of analyses (generally chronological) that are required in a risk assessment. These include: problem formulation, characterization of exposure, characterization of effects, and risk characterization. This terminology was developed and is used by EPA (1998).

The problem formulation is a planning process that is intended to ensure that the risk assessment is defensible and useful. In the context of a specific activity, the problem formulation includes:

1) the characterization of the activity,

2) the selection of susceptible assessment endpoints (ecological populations, communities, or ecosystems

that installation managers are required or want to protect)

3) the definition of the spatial and temporal extent of the activity,

4) the development of a conceptual model for exposures associated with the activity, 
5) the selection of measures of exposure (e.g., locations of wildlife, decibels at ground level), and

6) the selection of measures of effects (e.g., reduction in number of offspring).

The characterization of exposure is the estimation of the expected intensity, time, and extent of cooccurrence or contact with sound or another stressor by receptors. Along with the characterization of effects, it constitutes the analysis phase of the risk assessment. In this volume, exposure estimation methods are presented for each of the stressors associated with low-altitude overflights. Most relate to sound pressure or a combination of sound and visual stressors. Broadly, exposure estimation methods include:

1) a description of the activity (where that provides sufficient information about exposure),

2) empirical models of exposure, and

3) mechanistic models of exposure.

The characterization of effects is the definition of exposure-response relationships that are related to assessment endpoints. These may be generic, based on published studies, or they may be derived from biological surveys or tests conducted at the site. They include:

1) empirical models,

2) mechanistic models, and

3) thresholds (i.e., effects only occur above a certain exposure).

The risk characterization is the integration of site-specific estimates of exposure with site-specific or generic exposure-response models. The risk characterization consists of a weight of evidence, and effects of multiple stressors and indirect effects of stressors are incorporated. A significant part of the risk characterization is the estimation of uncertainty and variability.

In the text below, guidance is given for conducting ecological risk assessments for low-altitude overflights of military aircraft. The report is structured according to the EPA ecological risk assessment framework. The problem formulation (planning) process is emphasized, so that the assessment will ultimately be useful to decision makers. Susceptible ecological receptors which are likely to be valued on or near military installations are listed. Relevant scientific literature related to exposure and ecological responses to low-altitude overflights is reviewed. The use of particular models is recommended to minimize the necessity for the assessor to acquire original data sources. Data gaps are identified so that decision makers may be aware of how solid the technical bases for their decisions are. The report constitutes detailed risk assessment guidance that should greatly reduce the time and funds required to conduct an environmental assessment of low-altitude overflights of military aircraft. It is recommended that the user of this guidance also read the generic risk assessment framework for military training and testing activities (Suter et al. 1998).

\section{PROBLEM FORMULATION FOR OVERFLIGHTS $\left(4^{1}\right)$}

\subsection{CHARACTERIZATION OF LOW-ALTITUDE AIRCRAFT OVERFLIGHTS (4.1)}

\subsubsection{Definition of Low-altitude, Military Aircraft Overflights}

${ }^{1}$ The numbers in parentheses following the headings are the sections of the generic framework (Suter et al. 1998) in which the component has been previously described. 
The military activity of concern in any natural resource risk assessment should be identified and described as specifically as possible. This framework addresses low-altitude, subsonic overflights by fixedwing and rotary-wing military aircraft. Such overflights are conducted for purposes of military training, testing, operational missions, and logistics. Standard descriptors of these activities are provided below and in Appendix A. This activity risk framework addresses ecological risks related to actions of aircraft takeoff, flight, and landing. It takes into account flight patterns and characteristics of flight, but does not include

risks related to separate actions such as dropping ordnance, equipment and personnel, aerial refueling spills, or jettisoning of fuel. Such activities would need to be addressed by a separate activity framework. With respect to the needs of particular installations, this may be considered a generic framework. The risk assessor must modify the definitions of activities that appear below, according to the purpose of the particular assessment and the site conditions.

In combat, many aircraft operate in altitudes as low as $30 \mathrm{~m}$ and at high airspeeds to defeat ground missile radars and to avoid sophisticated surface-to-air missiles, anti-aircraft artillery, and enemy fighters. Pilots must have long hours of realistic training to become skilled at low-altitude flight; and then must have many more hours of the same training to remain proficient. Low-altitude flying training provides this realism and is considered one of the military's highest training priorities. A number of aspects of overflights and their contextual circumstances may affect the potential for ecological risk: military mission aspects, operational constraints and guidelines, equipment, and the environmental context.

\subsubsection{Military mission functions}

Low-altitude aircraft actions vary according to the purpose of the overflight mission. Types of mission functions that affect the nature of overflight activities include:

- transport of troops, airlift, airdrop, evacuation;

- transport of weapons or supplies;

- weapons delivery;

- $\quad$ airborne platform for command and control, communications, or surveillance;

- $\quad$ close air support of ground forces;

- air interdiction;

- $\quad$ armed reconnaissance, penetration and infiltration into enemy territory;

- $\quad$ security for fielded combat units;

- $\quad$ search and rescue under combat and non-combat situations;

- $\quad$ bombing and other offensive strikes; and

- aerial refueling.

\subsubsection{Relevant characteristics of overflights}

Variations in mission purpose can affect low-altitude overflight characteristics that potentially relate to ecological risk. Examples of parameters that change with the mission purpose are:

- $\quad$ the number of takeoffs and landings that occur during an exercise or other activity;

- $\quad$ the types of flight patterns that are flown during an action;

- $\quad$ the altitude ranges;

- $\quad$ speed of the aircraft;

- duration of time in flight;

- number of aircraft involved; and

- types of aircraft involved.

All of these are measures of exposure that may be used to estimate effects on natural resources (Sect. 2.5).

\subsubsection{Operational constraints and guidelines}


The military services are committed to safety and to minimizing the collateral noise associated with low-level flight training. The U. S. Air Force, for example, has set numerous restrictions and tailored its training to reduce noise as much as possible. The DoD in general, in addition to following its own flying rules of low-level altitudes and airspeed, also follows those in Federal Aviation Regulation 91.79 which states that no plane may fly closer than "500 ft [152 m] from any person, vessel, vehicle, or structure." (USAF Fact Sheet 96-17) In addition, because of the greater potential for human annoyance during sleeping hours, low-level flying by military fixed-wing aircraft generally occurs during daylight hours; low-level flying near densely populated areas is prohibited. (Nighttime helicopter training is required (USACHPPM 1998)). Nap-of-the-Earth (NOE) flying refers to very low flying, which keeps sound close to the ground, reducing community annoyance (USACHPPM 1998). However, lower flights can lead to higher exposures and impacts on the wildlife immediately below the flight corridor.

Specific areas are designated as low-altitude flight space. Both the military and general aviation must take precautions in designated low-altitude airspace. Military training areas and routes are shown in Flight Information Publications and FAA charts. The military uses some airspace below $3050 \mathrm{~m}(10,000 \mathrm{ft})$ for training operations and frequently flies at speeds of more than $460 \mathrm{~km} / \mathrm{h}$ ( $250 \mathrm{knots})$. High-speed operations include aircraft intercepts, air-to-air combat, close-air support for ground forces and photo reconnaissance. High-speed low-altitude training activities are conducted only in limited, charted airspace. Exceptions are made when absolutely required and are announced in advance.

Low-level airspace used for military flight activities includes alert areas and military training routes (MTRs). These are described in more detail in Sect. 2.3. Together, these comprise about one-half million square miles of domestic airspace (Brooks Air Force Base 1996).

- $\quad$ Alert areas are comprised of military operations areas (MOAs), restricted areas, and warning areas. A military operations area is airspace designated for non-hazardous military activity such as acrobatics, air combat tactics, and formation training. The U. S. Air Force has approximately 350 MOAs (Brooks Air Force Base 1996), and the U. S. Navy, Marines, and the Air National Guard use additional areas.

- $\quad$ Military training routes are used for military flight training at airspeeds in excess of $460 \mathrm{~km} / \mathrm{h}(250$ knots). Over 600 MTRs are in use by the U. S. Air Force (Brooks Air Force Base 1996), and the U. S. Navy, Marines, and the Air National Guard use additional MTRs. Two types of military training routes are used: those used under instrument flight rules and under visual flight rules. Instrument flight rules are for low-altitude navigation and tactical training below $3050 \mathrm{~m}(10000 \mathrm{ft})$ and at airspeeds in excess of $460 \mathrm{~km} / \mathrm{h}$ (250 knots) at night and in foul weather. Visual flight rules are for low-altitude navigation and tactical training below $3050 \mathrm{~m}$ at airspeeds in excess of $460 \mathrm{~km} / \mathrm{h}$ under visual flight rules.

Although an interagency agreement between the U. S. Fish and Wildlife Service, the National Park Service, the Bureau of Land Management and the Federal Aviation Administration imposes a voluntary altitude restriction of $610 \mathrm{~m}$ (2000 ft) for overflights above lands administered by the Department of the Interior, the Department of Defense is not bound by this agreement. Policies regarding lands near DoD installations are typically negotiated locally.

\subsubsection{Types of aircraft}

In addition to the effects of mission function, the type of aircraft may be related to exposure to stressors and ecological effects. Sound levels of aircraft, a potentially significant stressor to ecological receptors (Sect.

2.1.3), vary by factors such as:

- whether the aircraft is fixed-wing or rotary-wing 


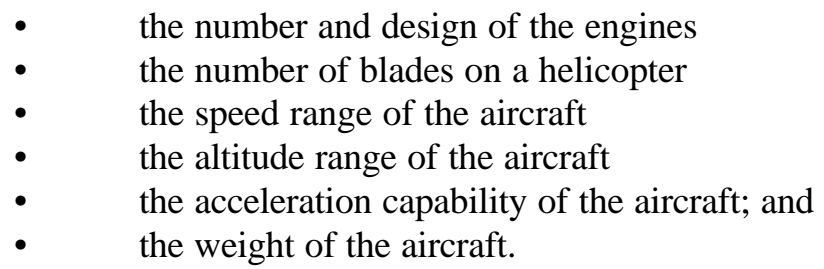

Some types of training, called "dissimilar air combat training," may consist of different types of aircraft training together. Information about specific aircraft can be found in Appendix A, though sound level data on new airframes may be lacking.

\subsubsection{Take-off and landing areas}

Aircraft take-off and landing areas consist of a variety of paved and unpaved surfaces. Variations in these locations affect ecological exposures associated with take-off and landing. Take-offs and landings can occur:

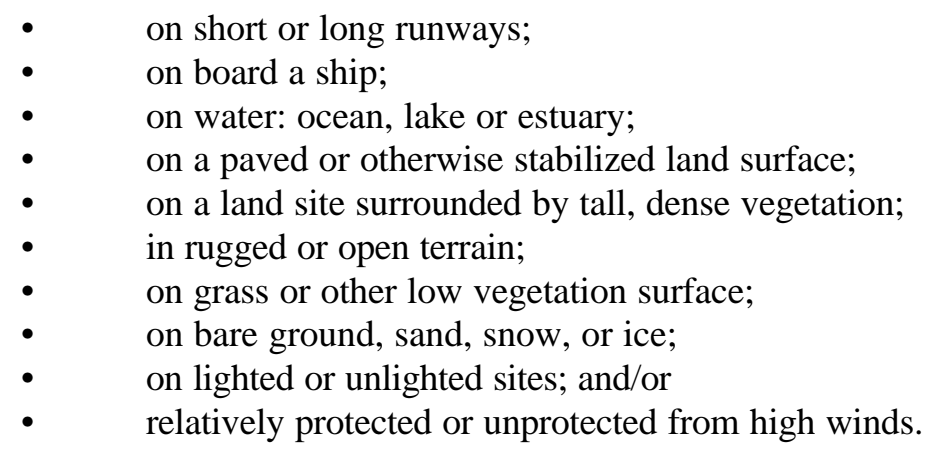

The take-off and landing conditions may control the type of aircraft used for the activity. For example, site conditions may dictate whether the aircraft should be fixed-wing or rotary-wing, large or small, heavy or light, fast or slow. In addition, the areas may control the number of aircraft a site can handle during a given time period.

\subsubsection{Environmental contexts}

Overflight activities can occur in different environmental contexts, which may affect the probability or magnitude of ecological risk associated with the activity. Low-altitude flights can occur:

- $\quad$ over land, water, snow or ice;

- $\quad$ during day or night ;

- $\quad$ over smooth, rough, heavily vegetated, or open terrain;

- $\quad$ during different seasons of the year; or

- $\quad$ under most weather conditions.

\subsubsection{Companion activities}

Numerous activities may be performed in conjunction with low-altitude overflights of military aircraft. A risk assessment for a training activity that involves low-altitude overflights may also include these activities, though they are not the subject of this assessment framework. Many Air Force activities are described in the Environmental Impact Statement for Alaska Military Operations Areas (Dept. of the Air Force 1995).

- $\quad$ Activation of flares. In general, burning material does not reach the ground.

- $\quad$ Release of chaff. These fine filaments of fiberglass with an aluminum coating may be released as a "burst" to reflect radar and obscure the aircraft. 
- $\quad$ Release of bomb dummy unit (BDU). These are inert munitions intended to simulate the ballistics of live ordnance.

- $\quad$ Release of free-fall bombs. Most consist of Mk-82 or Mk-84 that may be inert or live (containing H-6, Tritonal, or Minol II explosives).

- Release of laser-guided bombs. These consist of the free fall-bomb bodies and airfoil group, computer control group and guidance kit.

- $\quad$ Release of $20 \mathrm{~mm}$ and $30 \mathrm{~mm}$ ammunition. The ordnance can be one of four types: inert, target practice, high explosive, or high explosive, incendiary. Most training munitions are inert.

- $\quad$ Release of powered munitions (e.g., AGM-65 and AGM-130)

- $\quad$ Release of fuel.

- $\quad$ Release of external fuel tanks.

- $\quad$ Overflight by high-altitude aircraft that produce sonic booms.

\subsubsection{Component Actions (4.1.2)}

For any risk assessment related to a particular military activity, the assessor should list the actions that make up the activity. In general they should be presented in temporal sequence. The actions should be consistent components of the activity. For an aircraft overflight activity, the basic constituent actions are clear:

$\begin{array}{ll}- & \text { Takeoff } \\ \text { - } & \text { Flight } \\ \text { - } & \text { In-flight activity } \\ & \text { Landing. }\end{array}$

In-flight activity may consist of numerous, well-defined component actions. For example, hard turns, climbs, and dives are components of "low-altitude step down training" (Dept. of the Air Force 1995). As an example, the following description could form the basis of a breakout into component actions:

Air combat tactics training involves three to four aircraft, designated as either friendly or enemy forces, and separated as far as possible in the maneuvering airspace. Training begins with opposing forces coming toward each other within specified altitude bands to ensure safe operation. The purpose of this training is team work, targeting and sorting, and intercepts tactics to enhance survival. (Taken from Department of the Air Force. 1995. Final Environmental Impact Statement, Alaska Military Operations Areas, 11th Air Force, Elmendorf AFB, Alaska, Appendix C-3)

To provide further detail for the component action breakout, the analyst could specify the altitude bands that will be used for each of the in-flight actions listed (team flying, targeting, sorting, interception), as well as more detailed description of the flight patterns and numbers of aircraft in the actions, and other characteristics of the activity. An activity description matrix format is provided in Appendix A to assist the analyst in outlining the component actions of the activity in question.

The risk assessor must add or delete training activities or component actions as appropriate for a particular assessment. For example, a particular assessment may not involve rotary-wing aircraft at all. Or the assessment may be focused on the marine environment, but the takeoffs may occur on land. Additional component actions should be added if they are included in the activity. For example, the training activity may include drops of explosives that present a fire hazard to a forest.

\subsubsection{Definition of the Stressors and Modes of Action of Overflights (4.1.4)}


As part of the problem formulation for a risk assessment of military overflight activities, the stressors and modes of action of stressors should be defined. Candidate stressors are presented in Table 1. Stressors are categorized broadly and may arise from several specific sources. For example, noise from helicopters consists of rotor noise, engine noise, gear box noise, and sometimes blade slap (Molino 1982). However, it is impossible to separate the intensity and frequency range of sound arising from each source during the activity. Sound pressure is treated as a single stressor, even though different frequencies of sound could be associated with different effects. Because supersonic flight should not occur at low-altitude, sonic booms are excluded from the list of potential stressors. Risk assessors should delete any stressors and modes of action that are not relevant to a particular assessment. For example, training exercises that occur at night will not represent visual stressors for many wildlife populations. If any stressors have been overlooked in Table 1, the risk assessor should add these.

Table 1. Stressors and their modes of action associated with overflights by fixed wing and rotary wing aircraft.

\begin{tabular}{|c|c|c|}
\hline Action & Stressor & Potential mode of action \\
\hline \multirow{5}{*}{$\begin{array}{l}\text { fixed wing or } \\
\text { rotary wing in- } \\
\text { flight activity, } \\
\text { takeoff or } \\
\text { landing }\end{array}$} & sound & $\begin{array}{l}\text { behavioral response of wildlife, auditory damage to wildlife, } \\
\text { interference with foraging or predation, interference with mating }\end{array}$ \\
\hline & $\begin{array}{l}\text { sound level at a } \\
\text { particular } \\
\text { frequency }\end{array}$ & $\begin{array}{l}\text { interference with signaling among wildlife, interference with } \\
\text { echolocation }\end{array}$ \\
\hline & $\begin{array}{l}\text { visual image or } \\
\text { shadow of aircraft }\end{array}$ & behavioral response \\
\hline & physical aircraft & direct collision with birds (birdstrike) \\
\hline & vibration & unknown \\
\hline \multirow{2}{*}{$\begin{array}{l}\text { fixed wing or } \\
\text { rotary wing } \\
\text { takeoff or } \\
\text { landing }\end{array}$} & heat & $\begin{array}{l}\text { scorching of nearby vegetation; melting of snow, ice, and permafrost, } \\
\text { changing local habitat }\end{array}$ \\
\hline & air movement & erosion and associated effects on plant community, stem breakage \\
\hline
\end{tabular}

The risk assessor and risk manager should be aware of whether or not particular stressors may constitute a risk to the mission, human health, or assessment endpoints other than natural resources. For example, bird strikes represent a risk to the mission, because aircraft are often lost as well as birds. Thus, components of the risk assessment for natural resources may contribute to non-natural resource goals.

\subsection{ENDPOINT SELECTION FOR OVERFLIGHTS (4.2)}

Assessment endpoints are explicit expressions of environmental values that are to be protected. The process of endpoint selection identifies which of the environmental entities are sufficiently valued to potentially change a management decision, are ecologically important and susceptible to the proposed activities, and are practical for assessment (EPA 1998). Susceptibility implies potential for a high level of exposure to stressors and/or a high degree of sensitivity to the stressors. These factors are summarized in the following sections. In addition, state and federal regulations must be considered in the choice of endpoints.

\subsubsection{Regulation and Policy}

Federal regulations and DoD policies may determine assessment endpoints for particular installations and ecosystems. These choices are not always based on susceptibility, which is discussed 
below. The regulations that are most relevant to the selection of endpoints include the Endangered Species Act and the Marine Mammal Protection Act. The Endangered Species Act requires that endangered species be protected at the individual level. To take is to "harass, harm, pursue, hunt, shoot, wound, kill, trap, capture, or collect, or attempt to engage in any such conduct" (16 U.S.C. §1532(19)). The Secretary of the Interior has defined harm as "an act or omission which actually injures or kills wildlife, including acts which annoy it to such an extent as to significantly disrupt essential behavioral patterns" (TVA v. Hill, 437 U.S. 153, 184-185, n. 30, 1978).

The Marine Mammal Protection Act requires that a permit be obtained from the National Marine Fisheries Service (NMFS) when any action "incidentally takes" a marine mammal, where "to take" means to " harass, hunt, capture, collect, or kill, or attempt to harass, hunt, capture, collect or kill" (50 CFR \$216.6). Two levels of "harassment"are defined in the 1994 reauthorization of the Act:

Level A Harassment: "any act of pursuit, torment, or annoyance which has the potential to injure a marine mammal or marine mammal stock in the wild."

Level B Harassment: "any act of pursuit, torment, or annoyance which has the potential to disturb a marine mammal or marine mammal stock in the wild by causing disruption of behavioral patterns, including, but not limited to, migration, breathing, nursing, breeding, feeding, or sheltering but which does not have the potential to injure a marine mammal or marine mammal stock in the wild."

Although these definitions of harassment aim to clarify the terms, they do not specify what types of behavior changes do not constitute harassment. For example, it is assumed that alert behavior of pinnipeds (e.g., looking upward at a passing aircraft) would not constitute harassment, because the aircraft would not have much potential to affect the population or ecology of the animal (pers. comm. Capt. Thomas Fetherston, Naval Undersea Warfare Center, 7/99.). The NMFS anticipates recommending standards related to the impacts of sound on cetaceans in the next year.

Additional regulations and federal orders that could constrain choices of assessment endpoints include: 1) Executive Order 11990 on wetlands management, 2) Executive Order 11988 on floodplains management, and 3) the Migratory Bird Treaty Act.

The Air Force Instruction 32-7064 on Integrated Natural Resources Management (USAF 1994) lists additional policy issues that should be considered during the selection of assessment endpoints:

- $\quad$ cooperative agreements between the Air Force and the U. S. Fish and Wildlife Service

- $\quad$ agreements among 101 state and federal agencies to conserve neotropical migratory birds

- $\quad$ the importance of controlling bird-aircraft strike hazard (BASH)

\subsubsection{Properties that Increase Exposure to Stressors (4.2.1)}

The land below military airspace is generally undeveloped land, which may be owned or leased by DoD or designated as national parks, wildlife refuges, or wilderness areas. Therefore, numerous ecological receptors may be potentially exposed to stressors associated with aircraft overflights. Potential receptors include those with habitats near an airbase or flight path or that migrate through the area. Also, birds that fly at the cruising altitude of the aircraft would have a high potential for exposure. Properties of potential receptors that would cause them to be more exposed to each of the stressors are listed in Table 2 below.

Table 2. Properties of potential receptors that would lead to increased exposure to stressors associated with low-altitude overflights. 


\begin{tabular}{|c|c|}
\hline Stressor & Property of receptor \\
\hline \multirow{10}{*}{ sound } & acute hearing \\
\hline & habitat in location directly below or near overflight \\
\hline & habitat in canyon or other area where noise intensity may be high \\
\hline & habitat in open area, without tree cover \\
\hline & flight ability (potential for location at altitude close to stressor) \\
\hline & dwelling on cliff (potential for location at altitude close to stressor) \\
\hline & diurnal activity (if flights are during daylight) \\
\hline & nocturnal activity (if flights are at night) \\
\hline & emergence of semi-aquatic species from water (e.g., pinnipeds on land) \\
\hline & presence in shallow water rather than deep water (e.g., whales, dolphins) \\
\hline \multirow{2}{*}{$\begin{array}{l}\text { visual image or } \\
\text { shadow of aircraft }\end{array}$} & nesting above ground level, on rock faces \\
\hline & habitat in open area, without tree cover \\
\hline \multirow{4}{*}{$\begin{array}{l}\text { physical aircraft (in- } \\
\text { flight collision) }\end{array}$} & flight at cruising altitude of aircraft (raptors, Thompson 1999) \\
\hline & use of habitat near flight paths and take-off and landing surfaces \\
\hline & wide or deep migration front of bird population \\
\hline & high average flock density \\
\hline \multirow{2}{*}{$\begin{array}{l}\text { air movement assocd. } \\
\text { with takeoff, landing }\end{array}$} & preference for open or disturbed habitats \\
\hline & preference for arid or sandy soil (with low aggregation) \\
\hline vibration & sensory responsiveness to vibration \\
\hline
\end{tabular}

\subsubsection{Properties that Increase Sensitivity to Stressors (4.2.2)}

Numerous properties of potential receptors could cause them to be more sensitive to stressors associated with low-altitude overflights, particularly sound (Table 3). Whether or not these are properties that should be strongly considered during the selection of assessment endpoints depends on whether or not the assessor believes that the property may be associated with a credible effect on the assessment endpoint entity (e.g., survival or reproduction). For example, the reliance on auditory cues to locate a mate should not be impeded by infrequent overflights, if mates are in high supply.

Table 3. Properties of potential receptors that cause them to be more sensitive to stressors associated with low-altitude overflights. 


\begin{tabular}{|c|c|}
\hline Stressor & Property of sensitive receptor \\
\hline \multirow[t]{15}{*}{ Sound } & lack of previous exposure to sound level associated with activity \\
\hline & $\begin{array}{l}\text { nocturnal activity (nocturnal populations rely more on hearing than on sight to avoid predators } \\
\text { or locate prey, Manci et al. 1988) }\end{array}$ \\
\hline & reliance on auditory cues to locate young \\
\hline & reliance on auditory cues to locate mate \\
\hline & reliance on auditory cues to avoid predators \\
\hline & reliance on auditory cues to define territory and optimum population densities in an area \\
\hline & $\begin{array}{l}\text { reliance on natural sounds to provide information about landscape and wind speed (e.g., } \\
\text { migrating birds) }\end{array}$ \\
\hline & $\begin{array}{l}\text { reliance on auditory cues to emerge from hibernation (hypothesized in Brattstrom and } \\
\text { Bondello 1983) }\end{array}$ \\
\hline & reliance on auditory cues to detect prey or food (e.g., coyotes, bats, owls) \\
\hline & use of echolocation for navigation and/or locating predators or prey \\
\hline & sensitivity to sound while raising young (e.g., lambing, Air National Guard 1997) \\
\hline & sensitivity to sound during rutting (e.g., caribou) \\
\hline & sensitivity to particular frequency range of sound \\
\hline & low auditory threshold at relevant frequency ${ }^{1}$ \\
\hline & relatively high susceptibility to auditory damage \\
\hline \multirow{5}{*}{$\begin{array}{l}\text { Sound and } \\
\text { visual image } \\
\text { of aircraft }\end{array}$} & lack of previous exposure \\
\hline & tendency toward energy limitation, e.g., during winter months (e.g., deer, EPA 1980) \\
\hline & flocking or herding behavior (startle of a few animals leads to flight of many) \\
\hline & instinctive or learned reaction to perception of predator overhead \\
\hline & small window of time for reproduction \\
\hline $\begin{array}{l}\text { Visual image } \\
\text { of aircraft }\end{array}$ & diurnal activity \\
\hline \multirow[t]{2}{*}{ Vibration } & use of vibration sensors to detect movements of predators or prey \\
\hline & use of vibration sensors by organisms underground to detect key weather changes \\
\hline \multirow{5}{*}{$\begin{array}{l}\text { Air } \\
\text { movement } \\
\text { from takeoff } \\
\text { or landing }\end{array}$} & shallow plant roots \\
\hline & fragility of above-ground plant biomass \\
\hline & low cohesion of soil (e.g., low organic matter or moisture, small particle size) \\
\hline & sensitivity to dust coating and/or inhalation of particles \\
\hline & absence of vegetative cover (where soil structure is endpoint) \\
\hline Heat & small spatial scale of receptor \\
\hline
\end{tabular}

If exposure is measured or estimated external to the animal, then this is a property that increases sensitivity. If decibels are adjusted for acoustic thresholds of particular species, then this is a property that increases exposure.

One potential measure of sensitivity of wildlife to sound pressure is the acoustic threshold of the species at relevant frequencies of sound. Functions of threshold (in $\mathrm{dB}$ ) versus frequency of sound have been published for several species. Relevant parametters are listed in Table 4. Clearly, the relevant frequencies of aircraft sound are within the bounds of wildlife hearing (Table 4). In general, birds have similar auditory sensitivities at various frequencies of sound, and mammalian hearing is much more variable 
(Awbrey and Bowles 1989). For most birds, the acoustic thresholds at the optimum frequencies are higher than for mammals, and the hearing ranges are narrower for the former group (Awbrey and Bowles 1989).

Table 4. Parameters from auditory threshold curves for various species.

\begin{tabular}{|c|c|c|c|c|}
\hline Species & $\begin{array}{l}\text { Frequency of best } \\
\text { hearing }\left(f_{\text {opt }}\right), \mathrm{kHz}\end{array}$ & $\begin{array}{l}\text { Upper frequency } \\
\text { limit of hearing }\left(f_{u}\right) \text {, } \\
k H z\end{array}$ & $\begin{array}{l}\text { Lower frequency } \\
\text { limit of hearing }\left(f_{i}\right) \text {, } \\
\text { kHz }\end{array}$ & Reference \\
\hline human & 3.7 & $17^{1}$ & $0.025^{1}$ & Ehret 1977 \\
\hline cat & 8 & $65^{1}$ & $0.045^{1}$ & Ehret 1977 \\
\hline guinea pig & 8 & $50^{1}$ & $0.040^{1}$ & Ehret 1977 \\
\hline mouse & 15 & $100^{1}$ & $0.5^{1}$ & Ehret 1977 \\
\hline dolphin & 65 & $145^{1}$ & $0.7^{1}$ & Ehret 1977 \\
\hline horseshoe bat & 20 & $105^{1}$ & $3.0^{1}$ & Ehret 1977 \\
\hline least weasel & 1 to $16^{2}$ & $60.5^{2}$ & $0.051^{2}$ & $\begin{array}{l}\text { Heffner and } \\
\text { Heffner } 1985\end{array}$ \\
\hline kestrel & 1 to $2^{5}$ & $10^{2}$ & $0.1^{2}$ & $\begin{array}{l}\text { Awbrey and } \\
\text { Bowles } 1989\end{array}$ \\
\hline iguana & 1 to $1.1^{3}$ & 8 to $9^{3}$ & $0.1^{3}$ & $\begin{array}{l}\text { Wever and } \\
\text { Peterson } 1963\end{array}$ \\
\hline water snake & $0.2^{3}$ & $2.5^{3}$ & $<0.1^{3}$ & $\begin{array}{l}\text { Wever and } \\
\text { Vernon } 1960\end{array}$ \\
\hline pine snake & 0.1 to $0.2^{3}$ & $1.1^{3}$ & $<0.03^{3}$ & $\begin{array}{l}\text { Wever and } \\
\text { Vernon } 1960\end{array}$ \\
\hline garter snake & 0.2 to $0.3^{3}$ & $0.85^{3}$ & $0.045^{3}$ & $\begin{array}{l}\text { Wever and } \\
\text { Vernon } 1960\end{array}$ \\
\hline beluga whale & 20 to $60^{4}$ & $100^{4}$ & $1^{4}$ & $\begin{array}{l}\text { Richardson et al. } \\
1995\end{array}$ \\
\hline $\begin{array}{l}\text { California sea } \\
\text { lion }^{6}\end{array}$ & 1 to $30^{4}$ & $35^{4}$ & $0.4^{4}$ & $\begin{array}{l}\text { Richardson et al. } \\
1995\end{array}$ \\
\hline $\begin{array}{l}\text { California sea } \\
\text { lion }^{7}\end{array}$ & 2 to $8^{2}$ & $20^{2}$ & $1.2^{2}$ & $\begin{array}{l}\text { Richardson et al. } \\
1995\end{array}$ \\
\hline
\end{tabular}

frequency at which threshold is $65 \mathrm{~dB}$ higher than threshold for $\mathrm{f}_{\text {opt }}$

${ }^{2}$ frequencies audible at $60 \mathrm{~dB}$ sound pressure level

${ }^{3}$ frequencies audible at $20 \mathrm{~dB}$ sound pressure level

${ }^{4}$ frequencies audible at $100 \mathrm{~dB}$ sound pressure level

${ }^{5}$ frequencies audible at $10 \mathrm{~dB}$

${ }^{6}$ underwater

${ }^{7}$ in air

\subsubsection{Criteria for Susceptibility (4.2.4)}


The following criteria may be used to identify endpoint entities that are susceptible to low-altitude overflights, i.e., those that are either highly exposed or sensitive. Essentially, this is the union of properties in Sect. 2.2.1 and 2.2.2.

- $\quad$ habitat (terrestrial or marine) at location where sound pressure levels are high

- $\quad$ membership in class of birds that commonly fly at altitude of training activity (potential for direct collision)

- membership in class of birds or mammals that dwell in or on cliffs

- $\quad$ membership in class of organisms dwelling below military training routes or military operations areas

- $\quad$ habitat in open environment, with little tree cover

- membership in class of predatory birds which have keen vision for hunting and attacking approaching birds or aircraft

- $\quad$ membership in class of animals that are active during overflights

- $\quad$ auditory threshold below sound pressure at receptor location

- $\quad$ tendency to flush, run or fly when startled

- membership in class of animals that experience energy limitation in winter

- $\quad$ auditory structures susceptible to damage by aircraft frequencies and intensities (no current evidence of this)

- $\quad$ lack of previous exposure to activity and associated sound level

- $\quad$ reliance on auditory cues to locate mate or prey or to avoid predators, etc.

- $\quad$ membership in class of organisms that are preyed on by flying predators

- membership in class of organisms that use vibrations as signals

- $\quad$ membership in plant community or soil near takeoff and landing location

- membership in shallow-rooting plant community

- $\quad$ membership in community of plants with fragile stems

- membership in plant community (or population of endangered or threatened plants) of small spatial scale

\subsubsection{Generic Assessment Endpoints for Overflights (4.2.5)}

In a general, activity-specific framework, assumptions must be made about the types of endpoints that will be chosen for site-specific assessments. Guidance is given in Sect. 4.2.3 of Suter et al. (1998). Measures of exposure and exposure-response models cannot be compiled without choosing generic endpoints. However, it is sometimes advisable to select endpoints iteratively, during the compilation of effects thresholds and other exposure-response models. As stated above, assessment endpoints must be practical; i.e., effects information must be available. Generic assessment endpoints for the aircraft overflight activity are listed in Table 5. These include entities (populations, communities) and properties of the entities (reproduction, abundance). Organisms within each category are susceptible to aircraft overflights, based on descriptors in Sect. 2.2.4. They are likely to respond to sound, the visual image of the aircraft, collision with aircraft, and other stressors in a similar manner, based on similar exposures and behaviors, such as flocking, predation and predator avoidance. Assessment endpoints are not categorized based on taxonomy or similarity in acoustic thresholds, because insufficient data exist to determining whether or not lower acoustic thresholds are associated with greater population-level or behavioral effects.

Several groups of potentially susceptible endpoints are excluded because at the time of this writing, they are not practical choices (Sect. 2.2); i.e., relevant effects information is not available. These include: songbirds, bats, bees, and predatory mammals. For a risk assessment of low-altitude overflights to be complete, it is advisable to fill in research gaps related to impacts of sound on these populations. Although biodiversity may be valued, it is not a practical endpoint for assessment because of the breadth of the 
category. We assert that the approach to select and assess risks to endpoints here is compatible with the value of biodiversity.

It is impractical to include all classes of wildlife as endpoints, though all are likely to be exposed. Those selected below are considered to be more susceptible than others. However, other populations may be credible endpoints if they are exposed to stressors in addition to overflights, and the goal is to determine the total risk to these populations. For example, an ongoing study at the U. S. Army Construction Engineering Research Laboratory is determining the impact of various military training noise sources on redcockaded woodpecker populations (Pater et al. 1999).

No effects information was located for vibration as a stressor. For example, although reptiles such as snakes can detect vibrations (Wever and Vernon 1960, Burger 1998), they are not a practical endpoint category because of the lack of information about impacts of sound or overflights on these populations. Similarly, vibration is important to the communication (Painterkurt and Schneider 1998a, Sandeman 1996) and regulation of queen behavior (Painterkurt and Schneider 1998b) of honeybees. And vibration triggers release of pollen grains, so that they are in the path of pollinating bees (e.g. rhododendron pollen on anther tip, King and Buchmann 1995). But it is unknown whether or not the vibrations associated with aircraft overflights would affect these behaviors and processes. Further research is needed.

Both the plant community and surface soil are susceptible to takeoffs and landings. The plant community may include forest, arid, semi-arid, tundra, or other communities. Surface soil is included in the list of endpoints because this is a risk assessment framework for natural resources rather than for biota only. Endpoints for a particular assessment may differ from those listed here due to site-specific considerations and criteria other than susceptibility to the activity (e.g., valued regional species).

Levels of effect should be a component of the endpoint description for specific assessments, but it is not possible to choose a general effects level of concern (e.g., 20\%) without input from all military services and other stakeholders. Thus, the level of effects is not generic and is not stated in this framework. However, it is important that the base managers and conservation staff identify a practical effects level prior to conducting the risk assessment.

Table 5. Generic activity-specific endpoints

\begin{tabular}{|l|l|}
\hline Entity $^{1}$ & Property \\
\hline populations of raptors & reproduction and abundance \\
\hline populations of waterfowl & reproduction and abundance \\
\hline populations of birds ${ }^{2}$ & abundance \\
\hline populations of ungulate mammals & reproduction and abundance \\
\hline populations of small mammals & reproduction and abundance \\
\hline populations of reptiles & reproduction and abundance \\
\hline populations of amphibians & reproduction and abundance \\
\hline individual pinnipeds (seals, walruses, sea lions) & reproduction, abundance, general behavior \\
\hline $\begin{array}{l}\text { individual cetaceans (whales, dolphins) and sirenians } \\
\text { (manatees) }\end{array}$ & reproduction, abundance, general behavior \\
\hline plant community & production \\
\hline surface soil & mass/area \\
\hline
\end{tabular}


${ }^{1}$ If entity is a threatened or endangered species, then the relevant entity for a risk assessment should be an individual of the species rather than a population, and the property would be mortality, reduced fecundity, or loss of habitat (i.e., due to abandonment).

${ }^{2}$ This endpoint refers to the collision stressor.

In this framework, it is assumed that many types of behavior are relevant to the assessment endpoint properties above (see Sect. 4.6). However, some, such as lifting of the head, looking toward the stressor, and alertness are not included.

\subsection{DEFINITION OF SPATIAL AND TEMPORAL EXTENT (4.3)}

The risk assessor should describe the properties that determine the spatial and temporal extent of the activity during the planning stage of the assessment. The spatial extent of the activity may be defined in terms of exposure: the area over which flights of various types occur, that area plus an area where the overflight can be heard and/or seen, or the area over which peak sound energy exceeds some sound threshold that is below the effects thresholds for all endpoints, e.g. 80 or $85 \mathrm{~dB}$. Richardson and Wursig (1997) define the "radius of audibility" as the "maximum potential radius of influence at a given time," which can be defined as the distance to the location where 1) the sound cannot be distinguished from the ambient sound level or 2) the animal's absolute hearing threshold. The spatial extent of the assessment should have upper and lower altitude bounds, since bird strikes do not occur on the ground. Take-off and landing areas should be defined separately from the overall spatial extent.

The spatial extent of overflights is partly defined by airspace restrictions. Within the National Airspace System, two types of airspace are available for military use: Special Use Airspace and Airspace for Special Use (Dept. of the Air Force 1995). Special Use Airspace includes:

- Military Operations Areas, where aerobatics, air combat tactics, transition, and formation training are conducted (on aeronautical charts).

- $\quad$ Restricted Areas, where hazardous military activities, such as the firing of weapons or aircraft testing, occurs.

- $\quad$ Controlled Firing Areas, where conditions are controlled to reduce hazards to other aircraft (not on aeronautical charts).

- Warning Areas, where military activities in international airspace occur.

Airspace for Special Use includes (Dept. of the Air Force 1995):

- $\quad$ Military Training Routes, where low-altitude navigation and tactical training occurs, typically below $3050 \mathrm{~m}(10000 \mathrm{ft})$ and above $460 \mathrm{~km} / \mathrm{h}$ (250 knots).

- $\quad$ Maneuver Areas, where aircraft may perform various training maneuvers.

- $\quad$ Air Refueling Routes, which consists of permanent air refueling airspace.

- $\quad$ Air Traffic Control Assigned Airspace, used by military and nonmilitary aircraft.

- $\quad$ Altitude Reservations, where training may occur with temporary approval from the FAA.

- Low Altitude Tactical Navigation Areas, where low altitude navigation training may occur at large scale at airspeeds at or below $460 \mathrm{~km} / \mathrm{h}$ (250 knots).

- $\quad$ Slow Speed Low Altitude Training Routes, where training at or below $457 \mathrm{~m}$ (1500 ft) aboveground-level altitude at $460 \mathrm{~km} / \mathrm{h}$ or less may occur.

An example of lateral dimensions of an overflight mission would be between 1000 and 2500 square nautical miles (Dept. of the Air Force 1995, Table N-1). Vertical dimensions may range from $150 \mathrm{~m}$ aboveground-level to $1500 \mathrm{~m}$. Although some missions take place above the base, others can fly up to $185 \mathrm{~km}$ (100 nautical miles) from the base (Dept. of the Air Force 1995, Table N-1). Often a particular Air Force 
base may not have area sufficient for training; therefore the training may be conducted over national forests or other federal land (Delaney et al. 1999).

The temporal extent of all overflight stressors is defined simply as the time during which overflights occur. Risk assessors may obtain this information from flight plans or from historical data about flight times and frequencies. Some training missions may take as little as under a minute (Air National Guard 1997), and others may occur during 16 hours in 1 day (Dept. of the Air Force 1995, Table N-1). The duration of takeoff and landing events is expected to be on the order of minutes. More relevant for determining exposure is how long an aircraft may be audible or visible above a particular location.

As part of the definition of the spatial and temporal extent of the assessment, the assessor must determine the relationship between the scale of the endpoints and the scale of the activity. Most of the generic assessment endpoints are wildlife populations that could be impacted at the scale of the assessment. Overflights are larger in spatial scale than other military activities that may disturb natural resources. For example, chemically contaminated sites are significantly smaller in scale. However, particular stressors associated with overflights, e.g., avian collisions with the physical aircraft, might not be frequent enough to impact the population of birds, particularly if mitigation measures are implemented. The relationship between the plant community and the area potentially impacted by takeoffs and landings must also be determined. If the community is large compared to the area that could be impacted, then production of a particular plant community may not be a credible endpoint. Then the choice about whether or not to include this potential endpoint would depend on the level of effect that is selected by site managers.

The assessor at each installation must define the actual spatial and temporal extents of overflights that are of concern for a particular assessment. The assessor should indicate the ground area and altitudes within which flights will occur and the area within which effects may occur. The assessor should indicate the locations at which takeoff and landing will occur and the area within which effects may occur. The assessor should indicate the times of day and dates within which the activities will occur.

\subsection{ACTIVITY-SPECIFIC CONCEPTUAL MODEL: GENERIC (4.4)}

\subsubsection{Nature of the Stressors (4.4.1)}

All of the stressors associated with low-altitude overflights are physical stressors that result in a transfer of energy. Properties of the stressors and environment that are relevant to fate and transfer of the stressors are listed in Table 6. The assessor should add or delete stressors that are appropriate for a sitespecific assessment.

Table 6. Properties of the stressor or environment that are relevant to the fate and transfer of stressors or to their mode of action.

\begin{tabular}{|l|l|l|}
\hline Stressor & Stressor properties & Environmental Properties \\
\hline \multirow{2}{*}{ sound } & $\begin{array}{l}\text { sound pressure level and } \\
\text { sound frequency range }\end{array}$ & air temperature and inversions \\
\cline { 3 - 3 } & & humidity \\
\cline { 3 - 3 } & & $\begin{array}{l}\text { density of air (dependent on temperature, } \\
\text { humidity, altitude) }\end{array}$ \\
\cline { 3 - 3 } & & air movement (speed and direction) \\
\hline
\end{tabular}




\begin{tabular}{|c|c|c|}
\hline Stressor & Stressor properties & Environmental Properties \\
\hline \multirow{15}{*}{$\begin{array}{l}\text { aircraft } \\
\text { collision with physical } \\
\end{array}$} & & $\begin{array}{l}\text { topographical and landscape factors (e.g., hills, } \\
\text { trees, buildings) }\end{array}$ \\
\hline & & water temperature \\
\hline & & $\begin{array}{l}\text { water density (factor of temperature, depth, } \\
\text { salinity, inclusions) }\end{array}$ \\
\hline & & water chemistry (e.g., magnesium sulfate) \\
\hline & & underwater topographic features \\
\hline & & currents, waves and other water movement patterns \\
\hline & & soil moisture \\
\hline & & soil type \\
\hline & & $\begin{array}{l}\text { ground cover (e.g., grass, forest duff, asphalt, } \\
\text { gravel) }\end{array}$ \\
\hline & & $\begin{array}{l}\text { underground features such as rock components and } \\
\text { hardpans: volume, placement, continuity }\end{array}$ \\
\hline & & soil porosity \\
\hline & speed of aircraft and size of & weather \\
\hline & & time of day or year \\
\hline & & phase of moon \\
\hline & & ground cover \\
\hline air movement from & landing pattern & topographical and landscape factors \\
\hline takeoff and landing & and & soil moisture \\
\hline & $\begin{array}{l}\text { Wind velocity below and near } \\
\text { aircraft }\end{array}$ & soil type \\
\hline & & ground cover \\
\hline
\end{tabular}

At a specific installation, the risk assessor must add or delete stressors, as appropriate.

\subsubsection{Mode of Propagation of Physical Effects (4.4.2)}

Models and references are presented for the calculation of the propagation of sound pressure levels. However, the assessor should be aware that if a noise contour program such as NOISEMAP is available, the program will have noise propagation algorithms embedded in it (Sect. 3.4). Sound pressure from overflights begins in air and may enter water.

The simplest equation for describing the propagation of sound is the spherical spreading equation, also called the "20 log R spreading loss" equation (Richardson et al. 1995). The equation applies in air and water where the sound does not contact surfaces: 


$$
L_{r}=L_{s}-20 \log R
$$

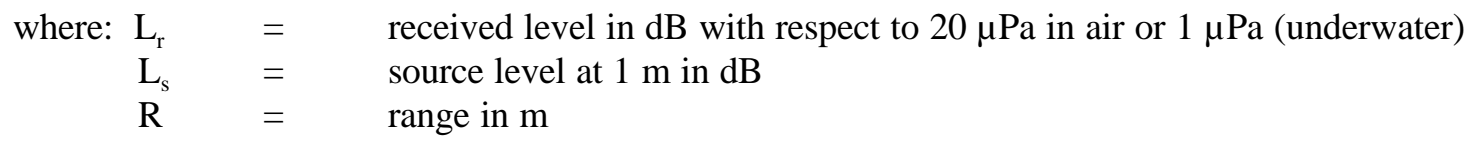

At frequencies below $30 \mathrm{kHz}$, sound is absorbed by oxygen and nitrogen molecules in air. In addition to frequency of sound, absorption is determined by temperature, relative humidity, and, to a lesser degree, atmospheric pressure (Richardson et al. 1995). Low frequency sound is transmitted well in air, with typical magnitudes of attenuation of sound in air at $4 \mathrm{~dB} / \mathrm{km}$ at $1 \mathrm{kHz}$ and $130 \mathrm{~dB} / \mathrm{km}$ at $10 \mathrm{kHz}$ (Richardson et al. 1995).

Sound may be reflected by hard surfaces and absorbed by soft ones. The ground effect is often not considered in models of sound propagation because reflection of sound does not contribute much to maximum exposures (at the height of the endpoint animal's ear). However, if the assessor wants to quantify the influence of the ground on the attenuation of sound, references for the effects of grass, trees, shrubs, asphalt and concrete on the propagation of sound may be found in Harrison (1978).

Sound may enter water by a direct refracted path, a horizontal wave, or by scattering from waves (Richardson et al. 1995). If seas are calm, noise at angles of greater than 13 degrees from perpendicular with water is largely reflected and not transmitted into water (Urick 1972). Much of the sound energy is reflected at the surface, but sound pressure doubles as the wave enters water (Richardson et al. 1995). In rough conditions, water surfaces at angles to the horizon may be suitable to facilitate transmission (Richardson et al. 1995). If a sea state is 2 or higher and at frequencies greater than $150 \mathrm{~Hz}$, air-to-water transmission of sound at shallow grazing angles is increased (Richardson et al. 1995). If ice is present, it does not attenuate sound appreciably if the frequency range is less than $500 \mathrm{~Hz}$.

When sound is trapped between horizontal refracting or reflecting surfaces (e.g., between the surface and bottom in shallow water), it spreads cylindrically rather than spherically. Sound pressure levels decrease in proportion to the increase in area of an expanding cylindrical wavefront. Sound pressure varies inversely as the square root of the range. Thus the " $10 \log \mathrm{R}$ spreading loss" equation is (Richardson et al. 1995):

$$
L_{r}=L_{s}-10 \log H-10 \log R
$$

where: $\mathrm{H} \quad=\quad$ effective channel depth $(\mathrm{m})$

The effective channel depth may account for the fact that cylindrical spreading may only constitute part of the trajectory of the sound (part may be spherical). Sound travels five times more rapidly in water than in air (Bowles 1995).

The speed of sound increases with increased temperature, salinity and/or pressure. Refraction of sound occurs because of the gradient of these variables in the deep ocean (Richardson et al. 1995). The propagation of sound in shallow water is highly dependent on environmental factors. Some attempts to use parabolic wave equations (if water depth is less than $1 / 4$ wavelength) or acoustic ray theory (if water depth is greater than 5 times wavelength) are described in Richardson et al. (1995). A fraction of sound energy is absorbed in water as it is transmitted. Magnesium sulfate is a primary cause of absorption for frequencies between 10 and $100 \mathrm{kHz}$ (Richardson et al. 1995). The loss of sound energy due to absorption is directly proportional to the distance (range) and may be described by: 


$$
a=0.036 f^{1.5}
$$

where: $\mathrm{a}=$ absorption

$\mathrm{f} \quad=\quad$ frequency $(\mathrm{kHz})$

It is advisable to measure sound in shallow water, given the large degree of uncertainty associated with modeled exposures.

A single model for the air movement associated with low flights of various helicopters has been located (Teske and Kaufman 1997). The model is described in Sect. 3.4.4.

\subsubsection{Mechanisms of Direct Physical Effects (4.4.3)}

The mechanisms of action of major stressors associated with overflights are listed in Table 7.

Table 7. Mechanisms of action of stressors associated with fixed-wing and rotary-wing, low-altitude overflights.

\begin{tabular}{|l|l|}
\hline Stressor & Mechanism of action \\
\hline \multirow{4}{*}{ sound } & alarm or avoidance \\
\cline { 2 - 2 } & alteration of auditory threshold ${ }^{1}$ \\
\cline { 2 - 2 } & impaired vocal development in young due to impaired hearing ${ }^{1}$ \\
\cline { 2 - 2 } & masking of auditory signals ${ }^{1}$ \\
\cline { 2 - 2 } & interference with echolocation ${ }^{1}$ \\
\hline & $\begin{array}{l}\text { replication of natural sound triggering behavior (e.g., emergence } \\
\text { from hibernation) }\end{array}$ \\
\hline visual image of aircraft & alarm or avoidance \\
\hline & attack behavior \\
\hline physical aircraft & collision, direct impact \\
\hline air movement from takeoff and & soil loss through erosion \\
\cline { 2 - 2 } landing & plant stem breakage \\
\hline heat & scorching (and mortality) of vegetation \\
\hline
\end{tabular}

${ }^{1}$ Speculative only. These have not been demonstrated mechanisms of action of the sound levels associated with subsonic aircraft overflights.

\subsubsection{Mechanisms of Indirect Effects (4.4.10)}

Potential mechanisms of indirect effects of stressors associated with overflights are listed below. These do not include non-endpoint effects on an organism (e.g., changes in behavior or heart rate) that may ultimately be associated with the assessment endpoint property for that organism.

- $\quad$ Effects on abundance of prey organisms (mortality, decreases in production, or emigration) from noise, visual stressors, or bird strikes may affect populations of predators. 
- Effects on abundance of predators (mortality, decreases in production, or emigration) from noise, visual stressors, or bird strikes may affect populations of prey.

- $\quad$ The air movement associated with takeoffs and landings of rotary wing aircraft may directly impact soil (through erosion) and the plant community (through stem breakage). The adverse impact on plants is expected to lead to additional soil erosion, which may lead to additional plant loss. The adverse impact of soil loss may lead to decreased plant production. These are not exclusively indirect impacts; nonetheless, the magnitude of the risks will be underestimated, if indirect effects are not considered.

- $\quad$ Startle reactions of birds could be directly caused by the noise of aircraft. Movements of birds have been observed to lead to startle reactions of pinnipeds (Fay 1981).

\subsubsection{Generic Conceptual Model (4.4.12)}

The generic conceptual model for this overflight-specific risk assessment framework is presented in Fig 1. Five stressors are included: sound, sound and the visual image of the aircraft combined, the physical aircraft (collisions), air movement and heat. No information was available to relate vibration to effects, so this stressor is not included at this time. There is no reason to expect that rotary-wing and fixed-wing aircraft would have different mechanisms of effects.

Overflights are expected to result in behavioral responses of individual wildlife, which may lead to impacts on abundance and production of populations. Bird strikes may also occur, as stated above. Takeoffs and landings may result in similar effects on wildlife populations, with potential for additional effects on plant production and surface soil. Direct mechanisms of action are listed in Table 7.

Both erosion of surface soil and decrements in plant production can increase the probability of reduced plant production and erosion, respectively. Impacts on wildlife populations can result in effects on predator or prey populations.

\subsection{ACTIVITY-SPECIFIC MEASURES OF EXPOSURE (4.5)}

Measures of exposure should be identified in the problem formulation phase of the risk assessment for low-altitude overflights. Measures of exposure are metrics that are used to define the degree of exposure of endpoint receptors to the stressors generated by the overflights. These include the intensity of the stressor, measures of the temporal dimensions of exposure, and measures of the spatial dimensions of exposure. Temporal and spatial dimensions may include descriptions of either the stressor or the receptor. In addition, a description of the activity itself may constitute an adequate measure of exposure. The selection of an exposure-response model (Sect. 4.1) determines which measures of exposure are used. Potential measures of exposure for overflights are listed below in Table 8.

Risk assessors must query site managers regarding the type of exposure information that is available for the risk assessment. Of course, from the assessment perspective, it is optimal to know the types of aircraft, schedule and routes of all low-altitude training flights for the assessment time period. Although such information may be known for the next month or longer, security purposes may dictate that the information be provided to the risk assessor in probabilistic terms.

Table 8. Measures of exposure for ecological risk assessments of low-altitude overflight exercises.

\begin{tabular}{|l|l|l|}
\hline Stressor & Type of & Measure of exposure
\end{tabular}




\begin{tabular}{|c|c|c|}
\hline & measure & \\
\hline \multirow{10}{*}{$\begin{array}{l}\text { sound and } \\
\text { visual image } \\
\text { of aircraft }\end{array}$} & \multirow[t]{6}{*}{ activity } & type of aircraft ${ }^{1}$ \\
\hline & & average aircraft velocities ${ }^{1}$ \\
\hline & & average power setting for velocity (acceleration, deceleration) ${ }^{1}$ \\
\hline & & altitude (above-ground level) \\
\hline & & slant distance from receptor to aircraft \\
\hline & & lateral distance from receptor to aircraft \\
\hline & \multirow{3}{*}{$\begin{array}{l}\text { spatial } \\
\text { dimension }\end{array}$} & airspace units used ${ }^{1}$ \\
\hline & & spatial distribution of wildlife population \\
\hline & & terrain, e.g., digital elevation model \\
\hline & $\begin{array}{l}\text { temporal } \\
\text { dimension }\end{array}$ & frequency of flights (number of flights per unit time) \\
\hline \multirow[t]{8}{*}{$\begin{array}{l}\text { sound of } \\
\text { aircraft }\end{array}$} & \multirow[t]{6}{*}{$\begin{array}{l}\text { intensity and } \\
\text { frequency }\end{array}$} & $\begin{array}{l}\text { sound exposure level (SEL) of event, expressed with respect to } 1 \text { second } \\
\text { period }\end{array}$ \\
\hline & & $\begin{array}{l}\text { onset rate adjusted monthly day-night average sound level (DNL) expressed } \\
\text { with respect to } 24 \mathrm{~h} \text { period }\end{array}$ \\
\hline & & maximum sound pressure level ${ }^{2}$ \\
\hline & & sound frequency profile \\
\hline & & simulated low-altitude aircraft sound \\
\hline & & average intensity of background sound \\
\hline & $\begin{array}{l}\text { spatial } \\
\text { dimension }\end{array}$ & noise contour $^{1}$ \\
\hline & $\begin{array}{l}\text { temporal } \\
\text { dimension }\end{array}$ & frequency of flights (number of flights per unit time) \\
\hline \multirow{8}{*}{$\begin{array}{l}\text { physical } \\
\text { aircraft }\end{array}$} & \multirow{2}{*}{ activity } & aircraft velocity \\
\hline & & altitude \\
\hline & \multirow{6}{*}{$\begin{array}{l}\text { temporal } \\
\text { dimension }\end{array}$} & timing of tail winds for bird migration \\
\hline & & seasonal timing of bird migration \\
\hline & & frequency of bird flights at different times of day \\
\hline & & number of aircraft flights per unit time \\
\hline & & average time aircraft spent at different altitudes \\
\hline & & distribution of altitudes where birds fly, particularly during migration \\
\hline \multirow{5}{*}{$\begin{array}{l}\text { air } \\
\text { movement } \\
\text { from aircraft } \\
\text { takeoffs and } \\
\text { landings }\end{array}$} & \multirow[t]{3}{*}{ activity } & type of aircraft \\
\hline & & air velocity at various distances from aircraft landing or taking off \\
\hline & & background wind speed and direction \\
\hline & $\begin{array}{l}\text { temporal } \\
\text { dimension }\end{array}$ & frequency of takeoffs and landings (number per unit time) \\
\hline & $\begin{array}{l}\text { spatial } \\
\text { dimension }\end{array}$ & area with measured air speed above threshold \\
\hline
\end{tabular}


${ }^{1}$ These measures of exposure are parameters or outputs of noise contour simulations, such as that from the Air Force programs NOISEMAP, MR_NMAP, and ROUTEMAP.

${ }^{2}$ Sometimes defined as the sound pressure level exceeded $1 \%$ of the time during a noise event (Trimper et al. 1998).

Measures of exposure to sound may be classified into several categories. First are the parameters of noise contour models. These include the type of aircraft and aspects of flight plans or recorded flight data such as altitudes, power settings, number of monthly training flights, and airspace units used (Lucas and Lee 1985). Topography is not an input to current versions of NOISEMAP or MR_NMAP (Sect. 3.4.1).

The output of noise contour programs is the sound pressure level: maximum pressure or pressure averaged or integrated over some time period. Although some exposure-response models use sound level as the measure of exposure, others do not. For example, many effects thresholds are available in which distance to the aircraft (typically measured as above-ground altitude, but sometimes as distance from the overflight track) and type of aircraft are the only measures of exposure. Unfortunately, these are not precise measures (distance is usually an approximation), atmospheric conditions may not be known or replicated at the specific assessment location, and exposures from multiple noise stressors cannot be added unless distance is translated to intensity of sound.

In exposure-response models derived from field tests, it is usually impossible to distinguish sound from visual exposures. In a few tests, low-altitude aircraft noise is simulated using a digital sound system or other recording (Weisenberger et al. 1996).

The unit for measuring sound pressure is the decibel $(\mathrm{dB})$. The ear of humans and other species responds to sound intensity in a logarithmic way (Manci et al. 1988). The decibel is the logarithm of a ratio of two values of power, and equal changes in decibels represent equal ratios (Peterson and Beranek 1956). The meaning of the term has been extended to express the ratio between two sound pressure levels in acoustics. Thus,

$$
S P L=20 \times \log \left(\frac{P}{P_{r e f}}\right)
$$

where: $\mathrm{SPL}=$ sound pressure level in decibels

$\mathrm{P} \quad=\quad$ sound pressure in medium $(\mu \mathrm{Pa})$

$\mathrm{P}_{\text {ref }} \quad=\quad$ reference sound pressure in still air $(20 \mu \mathrm{Pa})$ or water $(1 \mu \mathrm{Pa})$

To add sound pressure levels (dB, Peterson and Beranek 1956),

$$
S P L_{1+2}=10 \times \log \left(10^{\frac{S P L_{1}}{10}}+10^{\frac{S P L_{2}}{10}}\right)
$$

where:

$$
\mathrm{SPL}_{1+2}=\quad \text { combined sound pressure level }(\mathrm{dB})
$$

Thus, the addition of 60 decibels and 70 decibels results in a sound intensity of 70.4 decibels. Based on this logarithmic scale, the intensity of background noise (typically less than $50 \mathrm{~dB}$ ) is not usually a significant 
contributor to the total sound intensity of overflights; the precision of effects levels does not usually justify the consideration of background sound levels (see Sect. 3.6).

Several measures of sound intensity may be related to adverse responses. Two that provide a description of a single overflight event are the maximum sound level $\left(\mathrm{L}_{\max }\right)$ and the sound exposure level (SEL). The maximum sound level is often the intensity that is recorded during scientific investigations of the impacts of low-altitude overflights on wildlife. The SEL combines the maximum noise level of a overflight and its duration. All of the acoustic energy of an event is normalized into one second (USAF 1998). SELs are typically up to $15 \mathrm{~dB}$ higher than the maximum sound level for an event. The SEL is sometimes considered the most applicable noise metric for evaluating effects of noise on wildlife (USAF 1998). However, to our knowledge, no evidence exists that demonstrates that an exposure to a noise level of $\mathrm{z} \mathrm{dB}$ for $\mathrm{y}$ seconds produces effects equivalent to an exposure to $10 \mathrm{z} \mathrm{dB}$ for $1 / 10 \mathrm{y}$ seconds.

A measure of sound that is used for community noise (and is therefore an output of noise contour software) is the equivalent continuous sound level $\left(\mathrm{L}_{\mathrm{eq}}\right)$. It is more predictive of responses to constant noises than transient sounds such as those produced by aircraft overflights (Bowles 1995).

$$
L_{e q}=L_{e x i}+10 \times \log N_{i}+10 \times \log (1 / t)
$$

where: $\begin{array}{lll}\mathrm{L}_{\text {exi }} & = & \text { sound level } \\ \mathrm{N}_{\mathrm{i}} & = & \text { ith occurrence of sound } \\ \mathrm{t} & = & \text { specified duration (e.g., } 1 \text { hour) }\end{array}$

$\mathrm{L}_{\mathrm{eq}}$ is typically A-weighted (see below).

The day-night average sound level ( $\mathrm{L}_{\mathrm{dn}}$ or DNL) is the 24-h $\mathrm{L}_{\mathrm{eq}}$ (Bowles 1995). This metric is commonly associated with human community effects (USAF 1998). A $10 \mathrm{~dB}$ adjustment is often added to sound exposure estimates if overflights occur between $10 \mathrm{pm}$ and $7 \mathrm{am}$. The adjustment is based on the fact that sounds are intruding on sleeping hours and ambient sound levels at night are on average $10 \mathrm{~dB}$ lower than during the day (USAF 1998). The day-night average sound level is also sometimes adjusted for the "surprise" associated with the sudden onset of aircraft overflights. The number of decibels added depends on the onset rate (rate of increase in sound level (e.g. $15 \mathrm{~dB}$ per sec) (USAF 1998). The adjusted metric is termed the Onset Rate Adjusted Day Night Average Sound Level $\left(\mathrm{L}_{\mathrm{dnr}}\right)$. Adjusted sound levels are not advisable for use in ecological risk assessments, unless consistency with associated effects is demonstrated. Indeed, although the DNL has been emphasized by the DoD and especially the Army as the primary noise exposure metric (USACHPPM 1998), this metric applies to community annoyance and is seldom related to behavioral or reproductive effects of wildlife.

Sound intensities are often expressed on an A-weighted basis. In A-weighting, the frequency is adjusted to represent the way the average human ear responds; the intensities of certain high and low frequencies are adjusted downward. In practice, sound power in the A-weighted spectrum is integrated over frequency (Richardson et al. 1995). Because the A-weighted scale represents a simplification of the acoustic response in humans, this adjustment is not entirely appropriate for wildlife (EPA 1980). Occasionally, researchers estimate appropriate decibel-weighting for other species (e.g., owls, Delaney et al. 1999). However, acoustic responses are unknown for most wildlife species, and many animals are assumed to have a similar sensitivities to the frequencies of aircraft sound as humans (e.g., caribou, Maier et al. 1998). 
A common measure of exposure is the distance from the aircraft to the endpoint. This measure is usually used if sound pressure level information is not available. However, this measure has two advantages: 1) distance is sometimes a better predictor of wildlife response than sound pressure (Delaney et al. 1999) and 2) distance incorporates both the acoustic and visual stressors associated with overflights.

Distance is typically expressed as an above-ground level (AGL) altitude or as a slant distance. In hilly or mountainous terrain, AGL is measured relative to the highest local ground elevation. Thus, altitudes measured with respect to valleys would be significantly higher.

Measures of exposure for stressors other than noise are less well-defined, primarily because exposure-response models are rare. Nonetheless, factors that should affect exposure are listed in Table 8 above.

Some measures of exposure relate to the assessment endpoint. Because the stressor and endpoint have to be in the same location at the same time for an exposure to occur, it is important to know the activities and mobilities of the potentially affected organisms. If these parameters are not known, then they may be expressed probabilistically. Similarly, organisms may be sensitive to some stressors or stressor levels only when they are engaged in certain activities. Thus, the activity budgets (i.e., the daily and seasonal time spent in different activities) for the organisms are important.

\subsection{ACTIVITY-SPECIFIC MEASURES OF EFFECTS (4.6)}

Measures of effects must also be identified in the problem formulation. With knowledge of these measures, the assessor can determine the types of data that may be obtained or generated and the models that must be generated in order to perform the analysis of effects. The measures of effects may be obtained from field studies, from the laboratory, or from observations at the specific site of concern. Candidate measures of effects of low-altitude overflights are listed below.

The following measures of effect of low-altitude aircraft overflights directly relate to endpoint properties (population-level effects on wildlife, plant production, mass of surface soil):

- $\quad$ sound pressure level or slant distance from overflight that results in startling of adult that directly impacts young (e.g., kicking eggs out of nest, nest abandonment),

- $\quad$ sound pressure level or slant distance from overflight that results in mortality due to premature fledging of young,

- $\quad$ sound pressure level or slant distance from overflight that results in disruption of foraging for significant periods of time,

- $\quad$ air movement or frequency of takeoffs and landings that are associated with erosion of soil,

- air movement or frequency of takeoffs and landings that are associated with mortality of plants,

- type of aircraft that is associated with erosion and plant mortality at a certain spatial scale, and

- frequency of overflights that is associated with a probability of bird strikes

The following measures of effect of low-altitude aircraft overflights do not directly relate to endpoint properties, but these may be predictors of endpoint properties:

- $\quad$ sound pressure level that results in auditory injury,

- $\quad$ sound pressure level that results in impaired vocal development in young,

- $\quad$ sound pressure level or slant distance from overflight that results in behavioral changes as subtle as organism movement (e.g., flushing from nest, female nest attentiveness),

- $\quad$ sound pressure level or slant distance from overflight that results in flight response,

- $\quad$ sound pressure level that results in increased heart rate,

- $\quad$ sound pressure level that results in increased neural or endocrine activity, 
- $\quad$ sound pressure level that results in temporary auditory threshold shift

- $\quad$ frequency of sound that masks signaling among organisms,

- $\quad$ sound pressure level that alters the distance at which individuals of a species can communicate,

- $\quad$ sound pressure level that interferes with communication within the species,

- $\quad$ pressure and frequency of sound that result in disorientation,

- $\quad$ sound pressure level or slant distance from overflight that results in protest calls,

- $\quad$ sound pressure level or slant distance from overflight that is associated with a certain time to recovery (preflight behavior or maintenance behavior),

- $\quad$ pressure and frequency of sound that results in a disturbance of hibernation (especially problematic for toads in arid regions, where noise (thunder) may be an indication of rain),

- $\quad$ velocity of aircraft that is associated with the failure of birds in flight to escape from its path, and

- $\quad$ image of aircraft that elicits attack from raptor.

It is uncertain whether or not all of the measures of effects listed above can be related to the assessment endpoints. For example, what is the duration and increase in heart rate that is necessary before survival, reproduction, or habitat is affected? Models are needed to relate measures of effects to assessment endpoint responses (see Sect. 6.1.1). Included in the empirical effects models (e.g., thresholds) are responses such as panic, strong escape responses, and even mild escape responses (movement several meters away from the aircraft track), unless this latter category of effects was lumped with the not disturbed category in the relevant study (e.g., mountain goats in Côté 1996). It has been speculated that flushes from nests may be a good predictor of eventual reproductive loss (Awbrey and Bowles 1989). Alert responses (e.g., looking up, raising ears) are not included as measures of effects. All behavioral changes of marine mammals except for alert responses are included, such as diving and blowing, since harassment is not defined precisely in the Marine Mammal Protection Act. 


\section{CHARACTERIZATION OF EXPOSURE (5)}

\subsection{EXPOSURE ESTIMATION METHODS (5.1)}

Four types of exposure estimation methods are available for fixed- and rotary-wing aircraft overflights and other military stressors. These include a description of the activity, measurements of exposure, empirical models of exposure, and mechanistic models of exposure. Measurements are conducted at an installation, and are assumed to be representative of the entire assessment area or an entire population. Empirical relationships are derived from observations, usually of repetitive activities. For example, a certain maximum intensity of sound may be associated with a overflight by a particular type of aircraft at a specific slant distance from a receptor. Mechanistic models of exposure rely on a mechanistic understanding of the exposure process.

\subsection{DESCRIPTION OF THE ACTIVITY (5.2)}

An activity description for low-altitude overflights of fixed-wing and rotary-wing aircraft is presented in Sect. 2.1.1. Some descriptors of the activity constitute exposure parameters that are components of exposure-response models. These include:

- type of aircraft,

- $\quad$ altitude,

- $\quad$ slant distance,

- $\quad$ power setting,

- $\quad$ speed,

- location of flight,

- takeoff and landing surfaces,

- $\quad$ time of flight (day or night, dusk or dawn), and

- frequency of flights.

Sound levels at the location of the aircraft may be estimated based on the type of aircraft, power setting, and speed. Flight parameters may be obtained retrospectively from radar data or pilot interviews or prospectively from flight plans or discussions with training managers.

\subsection{MEASUREMENTS TO DETERMINE EXPOSURE AT INSTALLATIONS}

Measurements of sound levels at the location of ecological receptors or measurements of slant distance from the aircraft to the receptors can be taken at installations. More commonly, empirical or mechanistic models are used (below) that may depend on particular measurements. For example, measurement is far superior to modeling to estimate the locations of individual wildlife. Various measurement methods are listed in Table 9.

Table 9 Measurements of exposure that may be taken at individual installations.

\begin{tabular}{|l|l|l|}
\hline Stressor & Type of empirical exposure model & Example \\
\hline sound & $\begin{array}{l}\text { measurement of approximate noise } \\
\text { exposure of individual wildlife to sound }\end{array}$ & $\begin{array}{l}\text { collar capable of calculations of acoustic } \\
\text { descriptors for exposure of caribou to aircraft } \\
\text { noise events (Kugler and Barber 1993 abstract) }\end{array}$ \\
\hline
\end{tabular}




\begin{tabular}{|c|c|c|}
\hline Stressor & Type of empirical exposure model & Example \\
\hline & & $\begin{array}{l}\text { Animal Noise Monitor, integrated with global } \\
\text { positioning system (GPS) collar for large and } \\
\text { medium-sized animals, designed to dapture A- } \\
\text { weighted noise levels and onset rate of sound } \\
\text { (FICAN 1998) }\end{array}$ \\
\hline & & $\begin{array}{l}\text { several precision-integrating sound level meters } \\
\text { placed near groups of caribou (Maier et al. 1998) }\end{array}$ \\
\hline & & $\begin{array}{l}\text { audio capture and transmission system, part of } \\
\text { satellite tracking system for wide-ranging birds } \\
\text { (Seegar et al. 1996) }\end{array}$ \\
\hline & & $\begin{array}{l}\text { measurement of sound pressure levels in polar } \\
\text { bear den } 3 \mathrm{~m} \text { from location of Bell UH-1B takeoff } \\
\text { (Blix and Lentfer 1992) }\end{array}$ \\
\hline & $\begin{array}{l}\text { cumulative or probability distribution of } \\
\text { SELs for different overflights at site }\end{array}$ & $\begin{array}{l}\text { e.g., Fig. 4-38 in EIS for Colorado Airspace } \\
\text { Initiative (Air National Guard 1997) }\end{array}$ \\
\hline \multirow{3}{*}{$\begin{array}{l}\text { sound or } \\
\text { visual } \\
\text { image of } \\
\text { aircraft }\end{array}$} & $\begin{array}{l}\text { distribution of areas where significant } \\
\text { wide-ranging wildlife population activities } \\
\text { occur }\end{array}$ & $\begin{array}{l}\text { location of rutting, calving grounds of caribou } \\
\text { (Harrington and Veitch 1991) }\end{array}$ \\
\hline & $\begin{array}{l}\text { observation of timing of reproductive } \\
\text { activities of wildlife }\end{array}$ & fall rut of caribou (Harrington and Veitch 1991) \\
\hline & surveying of habitat on the installation & required by Air Force Instruction 32-7064 \\
\hline \multirow{6}{*}{$\begin{array}{l}\text { sound, } \\
\text { visual } \\
\text { image of } \\
\text { aircraft, or } \\
\text { physical } \\
\text { aircraft } \\
\text { (collisions } \\
\text { ) }\end{array}$} & $\begin{array}{l}\text { probabilistic models of wildlife } \\
\text { movements, including time in burrows }\end{array}$ & \\
\hline & observations of wildlife locations & $\begin{array}{l}\text { Gulf-Cet program of shipboard and aerial cetacean } \\
\text { surveys in the Gulf of Mexico (Wursig et al. } \\
\text { 1998) }\end{array}$ \\
\hline & location of wildlife using radiotelemetry & \\
\hline & location of wildlife using satellite tracking & $\begin{array}{l}\text { platform transmitter terminals for wide-ranging } \\
\text { birds (Seegar et al. 1996) }\end{array}$ \\
\hline & $\begin{array}{l}\text { distribution of individual wildlife in area of } \\
\text { influence per unit time }\end{array}$ & $\begin{array}{l}\text { distribution of observations of muskoxen } \\
\text { throughout the day on Prince of Wales Island, } \\
\text { Northwest Territories (Miller and Gunn 1979) }\end{array}$ \\
\hline & $\begin{array}{l}\text { location- and time-specific estimation of } \\
\text { presence of large flocks of birds via } \\
\text { weather radar }\end{array}$ & $\begin{array}{l}\text { use f National Weather Service WSR-88D radar } \\
\text { for tracking flights of roosting purple martins and } \\
\text { estimating their density in South Carolina (Russell } \\
\text { and Gauthreaux 1998) }\end{array}$ \\
\hline $\begin{array}{l}\text { air move- } \\
\text { ment, } \\
\text { takeoff } \\
\text { and } \\
\text { landing }\end{array}$ & $\begin{array}{l}\text { measurement of wind speed at ground level } \\
\text { for a distance around helicopter or fixed- } \\
\text { wing aircraft }\end{array}$ & \\
\hline
\end{tabular}


Several types of relevant empirical models of exposure are available. Most of these relate to the sound pressure stressor rather than to other stressors associated with low-altitude overflights. Types of empirical models are listed in Table 10. For all types of exposures, the exposure associated with the activity must be distinguished from background exposures, to the extent possible, because effects associated with background exposures are not due to the overflight.

Table 10. Empirical models of exposure of ecological receptors to stressors associated with low-altitude aircraft overflights.

\begin{tabular}{|c|c|c|}
\hline Stressor & Type of empirical exposure model & Example \\
\hline \multirow[t]{7}{*}{ sound } & $\begin{array}{l}\text { adjustment of sound intensity for } \\
\text { suddenness and nighttime, based on } \\
\text { assumed increase in effect due to startling } \\
\text { and increased sensitivity of nocturnal } \\
\text { species and exposures }\end{array}$ & $\begin{array}{l}\text { algorithms in NOISEMAP software and used in } \\
\text { Enhanced Training in Idaho. Environmental } \\
\text { Impact Statement (Dept. of the Air Force 1998) }\end{array}$ \\
\hline & \multirow[t]{5}{*}{$\begin{array}{l}\text { relationship between type of aircraft and } \\
\text { SEL at ground level }\end{array}$} & $\begin{array}{l}\text { Catalog of Noise Levels from Navy Aircraft (U. } \\
\text { S. Navy 1984) }\end{array}$ \\
\hline & & $\begin{array}{l}\text { A-weighted SEL for B-1B, F-15, F-16, A-10, C- } \\
130 \text { at different altitudes or slant distances (USAF } \\
\text { 1998, Fig. 4.2-1) }\end{array}$ \\
\hline & & $\begin{array}{l}\text { A-weighted SEL for } \\
\text { F-15 (450 knots, 85\% RPM), } \\
\text { F-16 (500 knots, 84\% RPM), } \\
\text { A-10A (325 knots), } \\
\text { F-14 (420 knots, 85\% RPM), } \\
\text { F-18 (450 knots, 86\% RPM), } \\
\text { A-6 (450 knots, 89\% RPM), } \\
\text { A-7 (420 knots, 90\% RPM) } \\
\text { B-1 (540 knots, 98\% RPM) } \\
\text { B-52G (340 knots, 88\% RPM) } \\
\text { C-130 (210 knots) } \\
\text { C-141 (300 knots, 85\% RPM), } \\
\text { F-111F (450 knots, 95\% RPM), } \\
\text { F-4 (420 knots, 90\% RPM), } \\
\text { F-5 (420 knots, 90\% RPM), } \\
\text { Tornado (445 knots, 94\% RPM) at various slant } \\
\text { distances (Dept. of the Air Force 1995, p. E-30) }\end{array}$ \\
\hline & & $\begin{array}{l}\text { A-weighted SEL for B-1B, B-52G, B-52H, C-17, } \\
\text { C-5, C-135B, C-141, KC-135A, KC-135R, F-4, } \\
\text { F-14, F-15, F-16, F-18, FB-111, T-38, A-6, A-7, } \\
\text { A-10, C-21, T-1A, T-37, T-39, T-43, C-12, C-130, } \\
\text { P-3 at } 305 \text { m slant distance operating at takeoff } \\
\text { thrust and airspeed (Dept. of the Air Force 1995, } \\
\text { Table F-2) }\end{array}$ \\
\hline & & $\begin{array}{l}\text { A-weighted SEL for F-18, AV-8, and A-6 at } \\
\text { different slant distances (Lucas and Lee 1995) }\end{array}$ \\
\hline & $\begin{array}{l}\text { relationship between type of aircraft and } \\
\text { maximum sound pressure at ground level }\end{array}$ & $\begin{array}{l}\text { maximum A-weighted sound levels for B-1B, F- } \\
\text { 15, F-16, A-10, C-130 at different altitudes } \\
\text { (USAF 1998, Table 4.2-1) }\end{array}$ \\
\hline
\end{tabular}




\begin{tabular}{|c|c|c|}
\hline \multirow[t]{13}{*}{ Stressor } & Type of empirical exposure model & Example \\
\hline & & $\begin{array}{l}\text { maximum A-weighted sound levels for B-1B, B- } \\
\text { 52G, B-52H, C-17, C-5, C-135B, C-141, KC- } \\
\text { 135A, KC-135R, F-4, F-14, F-15, F-16, F-18, FB- } \\
\text { 111, T-38, A-6, A-7, A-10, C-21, T-1A, T-37, T- } \\
\text { 39, T-43, C-12, C-130, P-3 at } 305 \text { m slant } \\
\text { distance operating at takeoff thrust and airspeed } \\
\text { (Dept. of the Air Force 1995, F-2) }\end{array}$ \\
\hline & & $\begin{array}{l}\text { peak sound levels for different overflight events (4 } \\
\text { nautical mile audible flight path; factors include } \\
\text { height, slant distance, power setting [takeoff, } \\
\text { cruise, approach]) (U. S. Navy 1998) }\end{array}$ \\
\hline & $\begin{array}{l}\text { relationship between sound pressure and } \\
\text { distance from flight track }\end{array}$ & \\
\hline & $\begin{array}{l}\text { relationship between measures of sound } \\
\text { pressure }\end{array}$ & $\begin{array}{l}\text { correlation between loudest overflight of day and } \\
\text { average sound level during military training in } \\
\text { Alaska (Maier et al. 1998) }\end{array}$ \\
\hline & \multirow[t]{3}{*}{$\begin{array}{l}\text { extrapolation of ground-level noise to that } \\
\text { in burrow }\end{array}$} & $\begin{array}{l}\text { SELs in small mammal burrows average } 2.4 \mathrm{~dB} \\
\text { lower than at } 1.2 \mathrm{~m} \text { above surface, with significant } \\
\text { attenuation above } 1300 \mathrm{~Hz} \text { (Francine et al. 1995) }\end{array}$ \\
\hline & & $\begin{array}{l}\text { SELs in kit fox dens are attenuated significantly } \\
\text { above } 500 \mathrm{~Hz} \text {; the function is in Francine et al. } \\
\text { (1995); more attenuation expected with bent } \\
\text { burrows }\end{array}$ \\
\hline & & $\begin{array}{l}\text { a sound pressure level of } 95 \mathrm{dBA} \text { is not lowered in } \\
\text { a lizard burrow of } 4 \mathrm{~cm} \text { of fine compacted sand } \\
\text { (Brattstrom and Bondello 1983) }\end{array}$ \\
\hline & $\begin{array}{l}\text { extrapolation of sound exposure associated } \\
\text { with one power setting to another }\end{array}$ & $\begin{array}{l}\text { noise levels are typically } 7 \text { to } 10 \mathrm{~dB}(\mathrm{~A}) \text { lower for } \\
\text { approach power settings than for takeoffs and } \\
\text { normal cruising speeds (U. S. Navy 1988) }\end{array}$ \\
\hline & \multirow[t]{4}{*}{$\begin{array}{l}\text { extrapolation of sound exposure from one } \\
\text { aircraft to another }\end{array}$} & $\begin{array}{l}\text { In a study of low-level overflights in Goose Bay, } \\
\text { Canada, maximum noise level did not differ } \\
\text { between F-4s and Tornadoes (Canadian Public } \\
\text { Health Association, as cited in Harrington and } \\
\text { Veitch 1991) }\end{array}$ \\
\hline & & $\begin{array}{l}\text { The F- } 4 \text { and F-18 are similar in noise output, and } \\
\text { the F-16 and the Tornado are similar in noise } \\
\text { output (Department of National Defence } 1989 \text { as } \\
\text { cited in Harrington and Veitch 1991) }\end{array}$ \\
\hline & & $\begin{array}{l}\text { noise levels for any military } 1 \text {-engine attack } \\
\text { Turbojet may be approximated by algorithms for } \\
\text { A7, A10, A4, F14, F16, F18, or F4 in FAA } \\
\text { Integrated Noise Model (FAA 1998a) }\end{array}$ \\
\hline & & $\begin{array}{l}\text { noise levels produced by E-2 aircraft are at least } \\
10 \mathrm{~dB}(\mathrm{~A}) \text { lower than those produced by jet } \\
\text { fighters (U. S. Navy 1998) }\end{array}$ \\
\hline
\end{tabular}




\begin{tabular}{|c|c|c|}
\hline Stressor & Type of empirical exposure model & Example \\
\hline & & $\begin{array}{l}\text { P-3 aircraft have same type of engine as E-2, but } 4 \\
\text { engines instead of } 2 \text {; thus, effects associated with } \\
\text { P-3 can be used to conservatively estimate effects } \\
\text { associated with P-2 (U. S. Navy 1998) }\end{array}$ \\
\hline & & $\begin{array}{l}\text { most helicopters with more than two rotor blades } \\
\text { are less noisy than Bell } 212 \text { (Richardson et al. } \\
\text { 1985a) }\end{array}$ \\
\hline & \multirow[t]{2}{*}{$\begin{array}{l}\text { extrapolation from A-weighted (human- } \\
\text { ear-weighted) decibels to wildlife- } \\
\text { weighted decibels }\end{array}$} & $\begin{array}{l}\text { assumption that auditory threshold curves for } \\
\text { species within a taxonomic order are } \\
\text { approximately the same (Delaney et al. 1999) }\end{array}$ \\
\hline & & $\begin{array}{l}\text { auditory threshold curves for Strigiformes (owls) } \\
\text { (Delaney et al. 1999) }\end{array}$ \\
\hline $\begin{array}{l}\text { sound or } \\
\text { visual } \\
\text { image of } \\
\text { aircraft }\end{array}$ & $\begin{array}{l}\text { estimation of timing of reproductive } \\
\text { activities of wildlife }\end{array}$ & fall rut of caribou (Harrington and Veitch 1991) \\
\hline $\begin{array}{l}\text { sound, } \\
\text { visual } \\
\text { image of } \\
\text { aircraft, or } \\
\text { physical } \\
\text { aircraft } \\
\text { (collisions } \\
\text { ) }\end{array}$ & $\begin{array}{l}\text { probabilistic models of wildlife } \\
\text { movements, including time in burrows }\end{array}$ & \\
\hline $\begin{array}{l}\text { visual } \\
\text { image of } \\
\text { aircraft or } \\
\text { physical } \\
\text { aircraft } \\
\end{array}$ & $\begin{array}{l}\text { model of how predatory birds see prey (and } \\
\text { similarity between image of prey and } \\
\text { aircraft) }\end{array}$ & \\
\hline \multirow[t]{2}{*}{$\begin{array}{l}\text { physical } \\
\text { aircraft }\end{array}$} & $\begin{array}{l}\text { factors that increase probability of bird } \\
\text { strikes }\end{array}$ & $\begin{array}{l}\text { food, shelter, open space, habitat (e.g., long grass), } \\
\text { surface water (Solman 1981) or standing water } \\
\text { from rainfall (Gabrey and Dolbeer 1996) located } \\
\text { at military airport }\end{array}$ \\
\hline & $\begin{array}{l}\text { location- and time-specific estimation of } \\
\text { presence of large flocks of birds via } \\
\text { weather radar }\end{array}$ & $\begin{array}{l}\text { use f National Weather Service WSR-88D radar } \\
\text { for tracking flights of roosting purple martins and } \\
\text { estimating their density in South Carolina (Russell } \\
\text { and Gauthreaux 1998) }\end{array}$ \\
\hline $\begin{array}{l}\text { air move- } \\
\text { ment } \\
\text { associated } \\
\text { with } \\
\text { aircraft } \\
\text { takeoff } \\
\text { and } \\
\text { landing }\end{array}$ & $\begin{array}{l}\text { estimation of wind speed at ground level } \\
\text { for a distance around helicopter or fixed- } \\
\text { wing aircraft }\end{array}$ & \\
\hline
\end{tabular}

The assessment of exposure must also include any policies that affect exposure. Most air bases expend much effort reducing the risk of bird strikes because of the risk to pilots and aircraft. The Alaska 
Military Operations Areas, for example, has two general recommendations on this topic (Dept. of the Air Force 1995). 1) It is suggested that overflights occur above the cloud layer during bad weather and at about $150 \mathrm{~m}$ above-ground-level altitude in good weather. 2) It is suggested that flight over rivers and within 3.7 $\mathrm{km}$ (2 nautical miles) on either side be avoided from April to October. The Environmental Impact Statement for the Alaska Military Operations Areas provides a Bird Aircraft Strike Hazard evaluation for each MOA during each month at dawn, mid-day, dusk, and night (Dept. of the Air Force 1995, Appendix $\mathrm{H})$.

\subsection{MECHANISTIC MODELS OF EXPOSURE (5.4)}

\subsubsection{Noise contour models}

A primary type of mechanistic exposure model that is available for sound is the spatial noise contour (isopleth) model. Estimated sound levels, based on the sound at the source and propagation through the air are plotted as contours on maps, often at intervals of 5 decibels of sound pressure. Features of a few of these models are detailed below. Sound levels may be measured at a specific location on an installation, or sound levels at the source may be obtained from published reports. It is suggested that the assessor display contours that are relevant to wildlife exposures; it is typical for contours that represent human "annoyance" or protection of public health and welfare to be displayed in Environmental Impact Statements. Key features of noise contour models are presented in Table 11.

NOISEMAP is one of a family of computer programs developed by the U. S. Air Force to estimate exposures to noise in the environs of an air installation due to aircraft flight, maintenance, and engine run-up activities (Dept. of the Air Force 1995). The software is also used to estimate noise contours from fixedwing flights by the Navy and rotary-wing flights by the Army. MR NMAP (MOA-Range NOISEMAP) is one version used to predict noise levels under Military Operations Areas, Military Training Routes, and Ranges (Lucas and Lee 1995). For military training routes, ROUTEMAP is sometimes used to estimate sound levels (FICAN 1998, Robert McKinley, pers. comm., April 1999). A distinction between the original NOISEMAP and these other versions is that NOISEMAP is used to calculate sound associated with slow aircraft taking off from and landing at airbases, and the others are for operations on MTRs and MOAs. The programs incorporate the physics of aircraft noise production and propagation. The models include track operations such as those on military training routes and target approaches and distributed operations such as those in military operations areas. Another version is MOAMAP, which uses Monte Carlo simulation of overflight activities to create a probability density function, which determines the likelihood that an aircraft will be located above a particular polygon at any point in time (Dept. of the Air Force 1995). NOISEMAP uses a PC/Windows platform, and the current version of MR_NMAP is 6.5. The estimation of noise contours with this program is undertaken during Environmental Impact Statements and Environmental Assessments. Some of the primary operators of the models are the U. S. Army Center for Health Promotion \& Preventative Medicine and various Airfield Operations Officers (USACHPPM 1998).

Also, the Noise Control Act, which is implemented through Air Force Instruction (AFI) 32-7063, requires all air installations to do an analysis of noise every two years for the Air Installation Compatible Use Zone Program (AICUZ). The information is used for land-use planning, but it should be available for all assessment needs (Brooks AFB 1996). The Air Craft Noise Effect Branch of Armstrong Laboratories collects and maintains aircraft noise data for the purpose of noise modeling (Dept. of the Air Force 1998). NOISENET is a noise monitoring and noise database management system used by airbases (FICAN 1998).

Two other programs are used with MR NMAP. MROPS (MOA-Range Operations) helps the user to define the airspace, aircraft types, and operations (Lucas and Lee 1995). NMPLOT (NoiseMAP PLOT) is the contour plotting program. 
The major feature which these models lack is the ability to account for the effects of topography on the propagation of noise. In addition, these models were not designed for use in predicting the propagation of noise from helicopters. Future modifications of NOISEMAP (version 7.0) are expected to include that feature, as well as parameters for special operations, such as vertical takeoffs and landings and hover (FICAN 1998).

The U. S. Army Center for Health Promotion and prevention notes that the Federal Courts have accepted the use of DoD computer noise models as adequately rigorous for Environmental Impact Statements (USACHPPM 1998).

Table 11. Noise contour models.

\begin{tabular}{|c|c|c|}
\hline Model & Description & Reference \\
\hline \multirow{8}{*}{$\begin{array}{l}\text { Military Operations Area } \\
\text { (MOA) Range NoiseMAP } \\
\text { (MR_NMAP) }\end{array}$} & Requires type of aircraft, frequency of sorties. & \multirow{8}{*}{$\begin{array}{l}\text { (Dept. of the Air } \\
\text { Force 1998, Air } \\
\text { National Guard } \\
\text { 1997, Dept. of } \\
\text { the Air Force } \\
\text { 1995, Brooks } \\
\text { AFB 1996, } \\
\text { FICAN 1998) }\end{array}$} \\
\hline & $\begin{array}{l}\text { Does not include wind, topography, or daily } \\
\text { meteorological conditions as inputs. }\end{array}$ & \\
\hline & $\begin{array}{l}\text { Propagation algorithms account for spherical spreading of } \\
\text { noise energy, atmospheric absorption, and lateral } \\
\text { attenuation as sound reacts with the ground. }\end{array}$ & \\
\hline & $\begin{array}{l}\text { Operations may be randomly distributed or confined to } \\
\text { specific tracks. }\end{array}$ & \\
\hline & Output is SEL, $\mathrm{L}_{\mathrm{dn}}, \mathrm{L}_{\mathrm{eq}}$, or $\mathrm{L}_{\max }$ versus slant range. & \\
\hline & $\begin{array}{l}\text { Adds decibels depending on rate at which noise from } \\
\text { approaching aircraft increases. }\end{array}$ & \\
\hline & May add $10 \mathrm{~dB}$ for nighttime operations (10pm to $7 \mathrm{am}$ ). & \\
\hline & Uses PC platform. & \\
\hline HELIOSLICE & Corridor model for helicopters. & $\begin{array}{l}\text { USACHPPM } \\
1998 \\
\end{array}$ \\
\hline \multirow{4}{*}{$\begin{array}{l}\text { Heliport Noise Model } \\
\text { (HNM) }\end{array}$} & Estimates heliport noise levels. & \multirow{4}{*}{$\begin{array}{l}\text { Fleming and } \\
\text { Rickley } 1994\end{array}$} \\
\hline & Rotor type, power plant, and horsepower important. & \\
\hline & $\begin{array}{l}\text { Has military helicopters in database, but NOISEMAP is } \\
\text { preferred by U. S. Army. }\end{array}$ & \\
\hline & Uses PC platform. & \\
\hline \multirow[t]{5}{*}{ Integrated Noise Model } & Standard methodology for noise modeling for the FAA & \multirow{5}{*}{$\begin{array}{l}\text { FAA } 1985, \\
\text { Dept. of the Air } \\
\text { Force } 1995\end{array}$} \\
\hline & Requires type of aircraft, number of operations & \\
\hline & $\begin{array}{l}\text { Output is contours of noise exposure including equivalent } \\
\text { continuous sound level }\left(\mathrm{L}_{\mathrm{eq}}\right) \text {, day-night average sound } \\
\text { level, and time above a specified threshold of A-weighted } \\
\text { sound }\end{array}$ & \\
\hline & $\begin{array}{l}\text { Version } 5.1 \text { includes a U. S. Air Force military aircraft } \\
\text { noise database }\end{array}$ & \\
\hline & PC platform, Microsoft Windows 95 & \\
\hline
\end{tabular}

\subsubsection{Habitat Models}

Data on the distribution of endpoint organisms are generally superior to models. However, if the installation does not collect these data (e.g., because of cost), conservation staff may survey habitat or use 
simulation models to predict the spatial distribution of potential habitat for these species (and to estimate the locations of these species). Air Force Instruction 32-7064 requires habitat inventories at 5-year intervals as part of the installation's Integrated Natural Resources Plan. However, these surveys may be too coarse to predict habitat of particular species.

Habitat Evaluation Procedures (HEPs) of the U. S. Fish and Wildlife Service may be used to determine the suitability of habitat for various species, and additional models are occasionally available that may be used to estimate population densities (scrub jays, Breininger et al. 1998; small desert mammals, Jorgensen et al. 1998; Henslow's sparrow, Cerulean warbler, and Karner blue butterfly, Dale et al. 1998), based on habitat. HEPs are typically used to assess the change in habitats over time, under the influence of land use changes or stressors. However, sound and other stressors associated with overflights are not among the variables that are currently used to define habitat for particular wildlife species. HEPs use both field data on abundance and production and indicators of habitat suitability to describe habitat (Rand and Newman 1998), based on the habitat suitability index (HSI). The HSI is a numerical representation of the ability of a habitat to support a species. Suitability indices that represent the ratio of a habitat variable (e.g., cover, food, water, land used seasonally) to the optimum value for that variable, within the range of 0 to 1 , are estimated and combined to give the HSI. An assumption of HEP is that there is a linear relationship between an environmental variable and biomass carrying capacity (USFWS 1980). The HSI that has been developed for the bald eagle (Haliaeetus leucocephalus), for example, predicts the quality of nesting habitat (Peterson 1986).

\subsubsection{Bird Strike Models}

Mechanistic models are available to predict avian exposure to physical aircraft via collisions. One of the first of these models was a bird migration hazard forecast system, based on average migration dates and weather forecast. This model was tested at Canadian Forces Base Cold Lake in Alberta (Blokpoel 1973). More recently, the Center for Conservation Research \& Technology, housed at the University of Maryland, Baltimore County, has developed an avian flight model based on weather, the Bird Flight Forecast and Information System. The model forecasts changes in weather (based on past weather and soil and vegetation data) and predicts timing of flight, direction and speed of flight, altitude of flight, and maximum daily travel distance (Shannon et al. 1999, CCRT 1998). Basically, changes in thermal updraft depth are correlated with vertical extent of soaring bird strike hazard. Researchers are currently developing relationships between meteorological and other environmental parameters and flight of American white pelicans, turkey vultures, black vultures, Swainson's hawks, and red-tailed hawks (Shannon et al. 1999). Other models that predict avian flight are also available. For example, one recent model estimates the optimum time of daily migration, based on wind conditions (Weber et al. 1998).

It is possible to calculate the probability of collision, based on density of birds in the flight corridor.

$$
N_{c}=\left[\left(\sum_{f=1}^{n} W_{f}\right) \times V \times t\right] \div A_{v}
$$

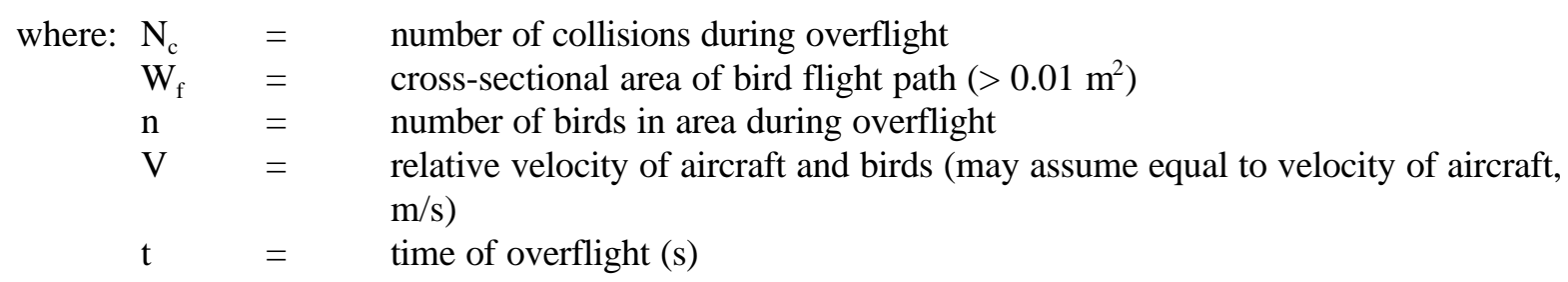


A $=\quad$ volume of air swept by aircraft (not volume of operations area) $\left(\mathrm{m}^{3}\right)$

If birds are all of one species, $\mathrm{W}_{\mathrm{f}}$ is constant.

If more than one flock is present,

$$
N_{c}=\left[\left(\sum_{f=1}^{n} W_{f}\right) \times V \times t\right] \div A_{v}
$$

where: $\mathrm{N}_{\mathrm{c}} \quad=\quad$ number of collisions during overflight

$\mathrm{W}_{\mathrm{f}} \quad=\quad$ area (width and height) of flock front $\left(\mathrm{m}^{2}\right)$

$\mathrm{n}=$ number of flocks in area during overflight

$\mathrm{V}=$ relative velocity of aircraft and flocks (may assume equal to velocity of aircraft, $\mathrm{m} / \mathrm{s}$ )

$\mathrm{t} \quad=\quad$ time of overflight $(\mathrm{s})$

A $=$ volume of air swept by aircraft (not volume of operations area) $\left(\mathrm{m}^{3}\right)$

\subsubsection{Air Movement Associated with Takeoffs and Landings}

A single model for the air movement associated with low flights of various helicopters is known (Teske and Kaufman 1997). The model was developed for the USDA Forest Service to estimate downwash and sidewash velocities associated with low-altitude hover and forward flight of helicopters used to spray pesticides or to spread water or fire retardants on forest fires. The maximum induced surface air velocity is:

$$
V=a S^{b} H^{c}
$$

where: $V=$ maximum induced surface air velocity $(\mathrm{m} / \mathrm{s})$

$\mathrm{S}=$ helicopter ground speed $(\mathrm{m} / \mathrm{s})$

$\mathrm{H}=\quad$ helicopter drop height (altitude, $\mathrm{m}$ )

$\mathrm{a}=\quad$ empirical constant $(1 / \mathrm{m}$, default 1.635$)$

$\mathrm{b}=\quad$ empirical constant (default -0.442$)$

$\mathrm{c}=\quad$ empirical constant (default -0.792$)$

Default values are based on field data from Bell 205H, Bell 206B, Blackhawk, Boeing Vertol BV-107, Chinook CH-47, Sikorsky S-61, and Skycrane (Teske et al. 1997). H is normalized by the helicopter rotor radius $\mathrm{R}$ (between $5.5 \mathrm{~m}$ and $11.0 \mathrm{~m}$ in test aircraft). $\mathrm{V}$ and $\mathrm{S}$ are normalized by the induced downwash velocity (w) calculated by:

$$
w=\frac{1}{R} \sqrt{\frac{M}{2 \pi \rho}}
$$

where: $\mathrm{w} \quad=\quad$ induced downwash velocity $(\mathrm{m} / \mathrm{s})$

$\mathrm{R}=$ helicopter rotor radius $(\mathrm{m})$

$\mathrm{M}=$ mass of helicopter $(\mathrm{kg})$ 
D $\quad=\quad$ density of air $\left(\mathrm{kg} / \mathrm{m}^{3}\right)$

A model also available to estimate the decay behavior of vortices near the ground (Teske et al. 1993). Models for estimation of air movement caused by takeoffs and landings of fixed-wing aircraft are not available. The air movement associated with fixed-wing aircraft is probably not as significant a stressor as helicopter rotor wash.

\subsection{RECOMMENDATIONS FOR EXPOSURE ANALYSIS (5.5 Exposure Profile)}

Exposure analysis is complete when contact between the stressor and the assessment endpoint entities has been estimated. This involves the estimation of the propagation of the stressor as well the estimation of or assumption about the distribution and behavior of the assessment endpoint entities. The first requirement is discussed below, stressor by stressor.

Limited information is available on the spatial distribution of animals and locations and timing of critical behaviors, such as reproductive activities. Radiotelemetry or satellite tracking is ideal, but these methods are often not affordable or otherwise feasible to support an environmental assessment at most installations. U. S. Army installations collect some mammalian distribution data, as part of the Land Condition - Trend Analysis Program, but these data are often limited to song birds and small mammals located along transects (Sprouse and Anderson 1996). If the installation does not have data on the numbers and distribution of animals of an endpoint population, the assessor must locate these data elsewhere or assume that the population is like some other population. Populations of marine mammals are probably surveyed more than most other populations. Key sources of this information are:

- $\quad$ Wildlife Exposure Factors Handbook (EPA 1993, http://www.epa.gov/nceawww1/wefh.htm). Contains information about life history for 15 bird species, 11 species of terrestrial mammals, 5 species of reptiles, and 3 species of amphibians. Intended as a reference for risk assessments related to chemical contamination.

- $\quad$ The Birder's Handbook (Erlich et al. 1988). Contains information about species distribution.

- $\quad$ The Birds of North America series (American Ornithologists' Union and Academy of Natural Sciences of Philadelphia, 1992 to present, http://www.birdsofna.org). One issue per species. Contains information about life history, such as timing of reproduction.

- Grzimek's Encyclopedia of Mammals (Grzimek 1990). Contains information about life history, such as timing of reproduction.

- Wild Mammals of North America : Biology, Management, and Economics (Chapman and Feldhamer 1982). Contains information about distribution and population densities of mammals.

\subsubsection{Sound}

To determine wildlife exposure to sound pressure associated with low-altitude military aircraft overflights, the sound levels at the locations of individual wildlife may be measured or estimated, or slant distance may be measured. The exposure in decibels may be estimated across lateral space, at appropriate vertical locations (e.g., nest level, ocean depth, burrow, cliff location), and at different times. The best measure of exposure to sound in the area of an overflight would be the collar or other audio capture system described in Table 8; this single measure would capture the location of the animals and the exposure to sound. However, such measurements may not be practical at most installations. NOISEMAP or MR_NMAP software is ideal for estimating sound levels at ground level. However, because the model is not currently suited to mountainous terrain, the outputs may be biased. The direction of the expected bias should be noted by the assessor. In addition, noise predictions for helicopters are highly uncertain. 
A series of measures of sound pressure are possible measures of exposure. The principal two measures that are part of exposure-response models are the SEL and $\mathrm{L}_{\max }$. It is not clear whether effects are better correlated to the maximum decibel level or to some measure that better represents the whole overflight event. Therefore, the risk assessor should use whichever measure is part of the relevant exposure-response models.

Decibels are most often expressed on an A-weighted basis. As stated above, weighting should be different for various mammals and birds. However, for any given species, the ratio between the acoustic threshold for humans at a given frequency and that for the other species is rather constant. So if an exposure response model for caribou uses $\mathrm{dBA}$ as the measure of sound pressure, there is no reason to translate it to caribou decibels.

The exposure due to the overflight is the measured sound pressure level minus a background level. The background level may be chosen to be: 1) a regional background value or 2) the level measured in the area prior to or following an overflight. Typically, background is not a significant contributor to the total sound, given the logarithmic scale of decibels (Sect. 3.6.7). However, if effects are measured when background noise is high, that contribution must be taken into consideration in the risk characterization.

If the animal's view of the aircraft is obscured (e.g., flights are at night, vegetative cover is high, or animal is in enclosed nest or burrow), slant distance may be used as the measure of exposure to sound from overflights. If aircraft are visible, then slant distance is a measure of exposure to both sound and the visual aircraft (Sect. 3.6.3). If it is assumed that the visual stressor is insignificant, then numerous equations are available for translating slant distance (with speed and power setting) to sound levels, such as the SEL (Table 8). These algorithms are embedded in NOISEMAP and the FAA's Integrated Noise Model, which is another reason to recommend this software. Similarly, recommendations concerning which aircraft noise parameters are similar enough to be substituted for noise parameters of other aircraft are presented in NOISEMAP literature as well as in other sources cited in Table 10.

The frequency of overflights is an important exposure parameter for all stressors. However, few exposure-response models incorporate this measure of exposure. This value may be important in translating from effects on behavior to effects on abundance or reproduction.

\subsubsection{Visual Image of Aircraft}

An exposure model for the visual image of the aircraft could be developed. This could consist of the amount of time that the aircraft is in view, the amount of time that the shadow passes over a wildlife individual, or the proportion of the field of view that is occupied by the aircraft, given its size and distance. However, an aircraft is never seen without also being heard. Also, no effects models that relate the image of the aircraft to an effect (without sound) are available. Therefore, the use of slant distance models (below) for estimating simultaneous exposure of wildlife to sound and views of aircraft is recommended if the aircraft is in the field of view.

\subsubsection{Sound and Visual Image of Aircraft, Combined}

The major measure or estimate of exposure to sound and the visual image of the aircraft is the slant distance, part of the description of the overflight. The slant distance only represents the visual stressor if the aircraft is within view. The altitude of the aircraft may be obtained from flight plans, pilot interviews, or historical averages. Slant distance is the hypotenuse of the right triangle that includes altitude and lateral distance to the assessment endpoint. If the overflight is almost overhead, slant distance may be assumed to be equivalent to altitude. If the overflight is low (e.g., $300 \mathrm{~m}$ or below) and over $1 \mathrm{~km}$ from the endpoint, 
the lateral distance is a close approximation of slant distance. Exposure to the acoustic and visual stressors vary with aircraft (size, power setting, engine type), meteorological and other environmental variables (wind, sunlight, precipitation, vegetative cover), and acoustic thresholds of the endpoint organisms.

If the only exposure-response models that are available for the endpoint class are for aircraft and environments different from those at the installation of concern, the biases associated with the use of these models must be noted.

\subsubsection{Physical Aircraft (Collision)}

Mechanistic models for the estimation of bird strike rates are provided in Sect. 3.5. Factors that increase the probability of bird strikes in these models include the presence of food, water, shelter, open space, habitat or migration routes at or near a military airport (Table 10). Other factors that could be incorporated into mechanistic models include: season, specific weather conditions such as a passing front, or time of day.

\subsubsection{Air Movement Associated with Aircraft Takeoffs and Landings}

Exposure parameters for estimating the risks from this stressor to surface soil mass consist of parameters of the mechanistic wind erosion effects model (Sect. 4.1.2). These consist of: wind velocity, soil particle size, soil moisture, temperature, vegetative cover, and slope of the land. The area that is exposed is the area impacted by air movement caused by the takeoff or landing. One way to determine this area is to set the land boundary at the location where the air movement from the aircraft (e.g., rotor wash from a helicopter) is equal to the average wind speed in the region.

A single model is available for the estimation of air velocities associated with helicopter takeoffs and landings. This is described in Sect. 3.5.4.

Vegetation cover data available at U. S. Army installations includes the Land Condition-Trend Analysis program data. Several elements are relevant to the modeling of erosion. These include vegetation data and physical and chemical characteristics of soil (Sprouse and Anderson 1996).

\subsubsection{Scorching of Vegetation}

No model is available to estimate the scorching of vegetation that is associated with takeoffs and landings. If the scale of this effect is sufficiently large to be a hazard to a valued plant community, empirical measurements of ground temperature or the spatial extent of scorched vegetation must be obtained from the assessment site or from similar activities. Exposure metrics would probably be descriptions of the activity: the type of aircraft and frequency of takeoffs and landings.

\subsubsection{Background Exposures}

In order to attribute an effect to stressors associated with overflights, the background levels of those stressors must be considered. It is not uncommon for risk assessments of chemical stressors to discover large contributions of background exposure to the total exposure. The primary stressor from overflights is sound. Average background sound pressure levels from environments where studies of the impacts of overflights have occurred are presented in Table 12. In one study, the primary sources of ambient sound were: wind, insect noise, and flowing streams (Air National Guard 1997).

\section{Table 12. Background sound pressure levels in various environments.}




\begin{tabular}{|c|c|c|}
\hline Location & Average measured sound level & Reference \\
\hline Huerfano County, southern CO & $31 \mathrm{~dB}^{1}$ & Air National Guard 1997 \\
\hline San Luis Valley, southern CO & $41 \mathrm{~dB}^{1}$ & Air National Guard 1997 \\
\hline Colorado and Mojave deserts of CA & $\begin{array}{l}14.0 \text { to } 66.0 \mathrm{dBA} \text { or } 30.0 \text { to } 70.5 \\
\mathrm{~dB}^{2}\end{array}$ & Brattstrom and Bondello 1983 \\
\hline $\begin{array}{l}\text { Jamaica Bay National Recreation area, } \\
2 \text { km from Kennedy International } \\
\text { Airport, New York }\end{array}$ & $77 \mathrm{dBA}$ & Burger 1981 \\
\hline $\begin{array}{l}90 \mathrm{~m} \text { to } 2 \mathrm{~km} \text { from Memphis } \\
\text { International Airport, Tennessee }\end{array}$ & 80 to $85 \mathrm{~dB}^{1}$ & Chesser et al. 1975 \\
\hline $\begin{array}{l}\text { Sacramento Ranger District of Lincoln } \\
\text { National Forest, south-central New } \\
\text { Mexico }\end{array}$ & $\begin{array}{l}25 \text { to } 35 \mathrm{~dB}^{1} \text {, or } 40 \mathrm{~dB} \text { on windy } \\
\text { days }\end{array}$ & Delaney et al. 1999 \\
\hline Barry M. Goldwater Air Force Range & $19 \mathrm{dBA}$ & Francine and Bowles 1995 \\
\hline $\begin{array}{l}\text { underwater near surface of ocean, } \\
\text { Hawaii }\end{array}$ & $90 \mathrm{~dB}$ re $1 \mu \mathrm{Pa}$ & Frankel and Clark 1998 \\
\hline $\begin{array}{l}\text { Desert National Wildlife Refuge, } \\
\text { Nevada }\end{array}$ & $65 \mathrm{~dB}^{1}$ & Krausman et al. 1998 \\
\hline Otero Mesa, southern NM & 36 to $40 \mathrm{dBA}$ & Luz and Smith 1976 \\
\hline sounds of surf in air & $61 \mathrm{dBA}, 64 \mathrm{dBA}$ & Richardson et al. 1995 \\
\hline $\begin{array}{l}\text { sounds of surf and seal pup } \\
\text { vocalizations }\end{array}$ & $68-69 \mathrm{~dB}^{2}, 1$ min. avg. & Bowles and Stewart 1980 \\
\hline
\end{tabular}

${ }^{1}$ Probably expressed on an A-weighted basis, but not clear from study.

${ }^{2}$ Unweighted.

Most of these values are very low, compared to maximum sound levels associated with low-altitude overflights by military aircraft, which are typically above $80 \mathrm{~dB}$ (Sect. 4). For example, because of the logarithmic nature of decibels, the addition of a $65 \mathrm{~dB}$ background exposure to an $80 \mathrm{~dB}$ overflight exposure increases the total exposure to about $80.14 \mathrm{~dB}$. In rural areas, the background contribution to a sound exposure level can usually be ignored. However, if the wildlife reside near an air base, the activities that are not the subject of the assessment (e.g., pre-existing overflights or testing of aircraft on the ground) should be included in the background exposure. Occasionally, natural exposures may contribute significantly to the total exposure to sound pressure. For example, rapids in the Naskaupi River near two osprey nests were spectrally similar enough to the mid- to higher frequency range of jet noise to mask maximum sound pressure levels of some overflights (Trimper et al. 1998). In addition, wind can prevent the perception of jet noise (Trimper et al. 1998).

Background sound levels can be measured in MOAs, MTRs, or near military airports. The background measurement should be taken when the overflights that are the subject of the assessment are not passing by. The background level may be ignored if it is $60 \mathrm{dBA}$ or less or if a natural area does not have a high level of insect noise, amphibian noise or sounds from flowing water. If the focus of an environmental assessment is on overflights of particular aircraft, then the contribution of the background 
sound level at an airport to any measured sound levels of takeoffs and landings of the particular aircraft of concern will probably be important. Similarly, if overflights occur in an area of high truck traffic and construction noise, the assessor should attempt to isolate this sound from the fraction of measured sound that is associated with overflights, the activity of concern. The risk assessor should report the background sound level and whether or not it is a major contributor to the total sound in the region during an overflight. The assessor should not estimate effects based on the total sound level in an area if the major contributor to the effects would be background sound levels.

Based on the background sound measurements above, the risk assessor may ignore background contributions to sound exposure if the background sound level is more than $15 \mathrm{~dB}$ lower than the sound level of the overflight. The background and overflight sound levels should be expressed in the same metric (e.g., same averaging period). The risk assessor may not measure the background sound level if the activity is in a rural area, and the assessor has confidence (based on experience) that the background sound level is much lower than the sound level associated with the overflight. However, as stated above, if the background sound (e.g., at an airbase) significantly contributes to the sound level when overflights are occurring, the assessor must determine the contribution of the overflights to sound exposure of wildlife. The assessor should report a measured background level of sound or a justification for not measuring it. 


\section{CHARACTERIZATION OF EFFECTS (6)}

\subsection{CHOOSE EFFECTS MODELS (6.1)}

The effects that are the subject of the assessment relate to abundance and production (Sect. 2.2.4). However, it is rare that these effects are measured directly, either at a particular installation or in the scientific literature. As stated above (Sect. 2.6), responses such as panic, strong escape responses, and even mild escape responses (movement several meters away from the aircraft track), are compiled in this report. Little evidence exists to link these behavioral changes to abundance or reproduction, but it has been speculated that flushes from nests may be a good predictor of eventual reproductive loss (Awbrey and Bowles 1989). Exposure-response models for alert responses (e.g., looking up, raising ears) are not presented or recommended. However, all behavioral changes of marine mammals, such as diving and blowing, are considered to be significant effects in this report, because harassment is not defined precisely in the Marine Mammal Protection Act.

Effects models consist of empirical models and mechanistic models. Empirical models are based on site-specific measurements or are obtained from field or controlled studies. In the latter case, these models are assumed to be at least somewhat generic. A special case of the empirical model is the threshold or threshold model. This is a single exposure value that is associated with a low level of effects. Mechanistic models are constructed from first principles; the mechanism of effects is known. Effects models relevant to aircraft overflights are listed below, by generic endpoint. Recommendations concerning which models to use are provided in Sect. 4.3.

The U. S. Air Force is the lead agency for research on effects of aircraft noise on wildlife (FICAN 1998). Thus, little research is available on effects of military-scale helicopter exercises on wildlife (which would be of primary concern to the Army) or effects of fixed-wing aircraft on ocean wildlife (which would be the major concern of the Navy).

\subsubsection{EMPIRICAL MODELS (6.1.1)}

Several types of empirical models exist or may be derived for estimating exposure-response relationships related to sound from low-altitude aircraft overflights. Models may be derived from site measurements or from published data. Of course, studies of impacts of overflights are limited by logistical and economic constraints; it is difficult to get flight time on military aircraft and to have control of the flight parameters. Opportunistic studies are much more common. Empirical data may be collected for the purpose of supporting the risk assessment, but these data are more costly to obtain than data for other types of risk assessments (e.g., risks from chemical contaminants). Empirical models include:

- $\quad$ threshold models,

- models relating sound pressure level to behavioral response,

- $\quad$ models relating distance from flight track (noise and visual stressors combined) to response,

- models relating frequency of overflights to response,

- $\quad$ models relating sound pressure level to duration of response,

- $\quad$ models relating sound pressure level (or distance to aircraft) to time to habituation,

- models relating habituation to level of effects,

- $\quad$ models relating measurable effect to assessment endpoint,

- $\quad$ models relating sound frequency spectrum to effects,

- $\quad$ models relating behavior prior to the overflight to the level of response,

- models relating probabilities of bird flights and probabilities of aircraft overflights to probabilities of direct collisions, 
- $\quad$ models relating wind speed from aircraft and environmental parameters to erosion, and

- $\quad$ models relating wind speed from aircraft to plant production.

Threshold models are described below, in Sect. 4.1.3. Methods and models for extrapolating from a measured effect to an assessment endpoint are presented in Sect. 4.3. Other types and examples of empirical models are presented in Table 13. If both threshold and non-threshold models are available, it may be appropriate to use both and weigh their results according to the relevance and rigor of the models.

Table 13. Empirical models of effects (not including simple thresholds) that are available for estimating effects of low-altitude aircraft overflights.

\begin{tabular}{|c|c|c|}
\hline $\begin{array}{l}\text { Assessment } \\
\text { endpoint }\end{array}$ & Type of empirical model & Example \\
\hline \multirow[t]{6}{*}{ raptors } & $\begin{array}{l}\text { level of response versus } \\
\text { distance }\end{array}$ & $\begin{array}{l}\text { net prey deliveries per unit time versus slant distance for } \\
\text { Mexican spotted owl (Delaney et al. 1999) }\end{array}$ \\
\hline & $\begin{array}{l}\text { level of response versus } \\
\text { frequency of overflights }\end{array}$ & $\begin{array}{l}\text { lower productivity of peregrine falcons at nest sites with } \\
\text { increased frequency of overflights by military jets (though } \\
\text { these birds had low productivity originally, D. Roby, personal } \\
\text { communication 3/99) }\end{array}$ \\
\hline & $\begin{array}{l}\text { frequency of response } \\
\text { versus slant distance }\end{array}$ & $\begin{array}{l}\text { frequency of flushing of Mexican spotted owls with distance } \\
\text { from helicopter overflight (Delaney et al. 1999) }\end{array}$ \\
\hline & $\begin{array}{l}\text { level of reproductive } \\
\text { response versus behavior }\end{array}$ & $\begin{array}{l}\text { number of young gyrfalcons per successful nest correlated to } \\
\text { frequency of flush response (Platt 1977, Awbrey and Bowles } \\
\text { 1989) }\end{array}$ \\
\hline & $\begin{array}{l}\text { time to habituation versus } \\
\text { sound pressure or distance } \\
\text { to aircraft }\end{array}$ & $\begin{array}{l}\text { avoidance behavior reduced with habituation of nesting red- } \\
\text { tailed hawks to helicopter activity (Andersen et al. 1989) }\end{array}$ \\
\hline & $\begin{array}{l}\text { probability of reproductive } \\
\text { impact, given frequency of } \\
\text { overflight }\end{array}$ & $\begin{array}{l}\text { probability of nesting and fledging success for overflight- } \\
\text { induced flushing of raptors, adjusted for habituation (Awbrey } \\
\text { and Bowles 1989) }\end{array}$ \\
\hline \multirow[t]{6}{*}{ waterfowl } & $\begin{array}{l}\text { probability of response } \\
\text { versus several variables }\end{array}$ & $\begin{array}{l}\text { probability of flight response from flock of brant, based on } \\
\text { altitude, lateral distance, noise, aircraft type, aircraft type times } \\
\text { altitude, aircraft noise times lateral distance (Ward et al. 1999) }\end{array}$ \\
\hline & $\begin{array}{l}\text { duration of response } \\
\text { versus flock size }\end{array}$ & $\begin{array}{l}\text { logistic relationship between flock size of molting brant and } \\
\text { duration of disturbance response (Derksen et al. 1992) }\end{array}$ \\
\hline & $\begin{array}{l}\text { probability of response } \\
\text { versus habituation }\end{array}$ & $\begin{array}{l}\text { proportion of overflights during which black ducks reacted } \\
\text { versus reaction rate and days of exposure when habituation } \\
\text { appeared to occur (Conomy et al. 1998) }\end{array}$ \\
\hline & $\begin{array}{l}\text { type of response versus } \\
\text { sound intensity }\end{array}$ & $\begin{array}{l}\text { mean proportions of crested tern colonies exhibiting various } \\
\text { behavioral responses to recorded aircraft noise (Brown 1990) }\end{array}$ \\
\hline & $\begin{array}{l}\text { level of response versus } \\
\text { frequency of overflights }\end{array}$ & $\begin{array}{l}\text { estimated energy balance of fall-staging snow geese } \\
\text { (kjoules/hr) was related to disturbance rate (\#/hr), where } \\
\text { disturbance consisted of overflights, other transportation- } \\
\text { related disturbances, hunting, etc. (Belanger and Bedard 1990) }\end{array}$ \\
\hline & $\begin{array}{l}\text { behavioral time budget } \\
\text { versus helicopter } \\
\text { disturbance frequency }\end{array}$ & $\begin{array}{l}\text { time spent grazing was reduced and swimming increased among } \\
\text { non-breeding pink-footed geese when exposed to overflights by } \\
\text { Bell } 212 \text { and Bell } 206 \text { helicopters (Mosbech and Glahder } \\
\text { 1991) }\end{array}$ \\
\hline
\end{tabular}




\begin{tabular}{|c|c|c|}
\hline $\begin{array}{l}\text { Assessment } \\
\text { endpoint }\end{array}$ & Type of empirical model & Example \\
\hline \multirow[t]{12}{*}{ ungulates } & \multirow[t]{3}{*}{$\begin{array}{l}\text { level of response versus } \\
\text { sound pressure level }\end{array}$} & $\begin{array}{l}\text { association of active and resting bouts of caribou with sound } \\
\text { intensity, as determined by animal noise monitors and activity } \\
\text { monitoring systems on radio collar (Maier et al. 1998) }\end{array}$ \\
\hline & & $\begin{array}{l}\text { daily time barren-ground caribou spend resting in late winter, } \\
\text { negatively related to time-averaged noise level (Maier et al. } \\
\text { 1998) }\end{array}$ \\
\hline & & $\begin{array}{l}\text { daily distance moved by post-calving barren-ground caribou } \\
\text { correlated to SEL for loudest overflight of day (Maier et al. } \\
1998 \text { ) }\end{array}$ \\
\hline & $\begin{array}{l}\text { level of response versus } \\
\text { altitude }\end{array}$ & $\begin{array}{l}\text { percentages of barren ground caribou displaying behavioral } \\
\text { responses at different overflight altitudes (Calef et al. 1976) }\end{array}$ \\
\hline & \multirow[t]{3}{*}{$\begin{array}{l}\text { level of response versus } \\
\text { frequency of overflights }\end{array}$} & $\begin{array}{l}\text { woodland caribou calf survival (no. survey periods that cow was } \\
\text { accompanied by calf) negatively correlated with number of jet } \\
\text { overflights reported }<1 \mathrm{~km} \text { from an animal's location per day } \\
\text { (relationship significant during the calving and immediate post- } \\
\text { calving periods for the females known to have calved and for all } \\
\text { females) (Harrington and Veitch 1992) }\end{array}$ \\
\hline & & $\begin{array}{l}\text { number of resting bouts of barren-ground caribou related to } \\
\text { number of overflights (Maier et al. 1998) }\end{array}$ \\
\hline & & $\begin{array}{l}\text { mean duration of resting bouts of barren-ground caribou } \\
\text { negatively related to number of overflights (Maier et al. 1998) }\end{array}$ \\
\hline & \multirow[t]{3}{*}{$\begin{array}{l}\text { response related to } \\
\text { behavior prior to overflight }\end{array}$} & $\begin{array}{l}\text { traveling and feeding caribou were similar in their level of } \\
\text { response; caribou at river crossings were more reactive than } \\
\text { traveling or feeding animals, and resting animals were less } \\
\text { reactive (Calef et al. 1976) }\end{array}$ \\
\hline & & $\begin{array}{l}\text { responses of caribou and muskoxen depend on previous activity } \\
\text { of animals (Miller and Gunn 1979) }\end{array}$ \\
\hline & & $\begin{array}{l}\text { more rapid running reaction of caribou and longer duration } \\
\text { when animals walking prior to overflight, compared to animals } \\
\text { feeding and standing or lying (Harrington and Veitch 1991) }\end{array}$ \\
\hline & $\begin{array}{l}\text { level of effects versus } \\
\text { habituation }\end{array}$ & $\begin{array}{l}\text { bighorn sheep and mule deer habituate to low-level aircraft } \\
\text { noise with increased exposure to overflights (Weisenberger et } \\
\text { al. 1996) }\end{array}$ \\
\hline & $\begin{array}{l}\text { level of response versus } \\
\text { environmental variables }\end{array}$ & $\begin{array}{l}\text { vegetation type and season were determinants of distances } \\
\text { moved by mountain sheep exposed to overflights by helicopters } \\
\text { (Bleich et al. 1994) }\end{array}$ \\
\hline \multirow[t]{3}{*}{ cetaceans } & $\begin{array}{l}\text { level of response versus } \\
\text { sound pressure level }\end{array}$ & $\begin{array}{l}\text { percentage of migrating gray whales changing course to avoid } \\
\text { projection of sound at various intensities (Malme et al. 1984) }\end{array}$ \\
\hline & \multirow[t]{2}{*}{$\begin{array}{l}\text { level of response versus } \\
\text { altitude }\end{array}$} & $\begin{array}{l}\text { blow intervals of bowhead whales when Islander aircraft } \\
\text { descended from one altitude to one or two others (Richardson } \\
\text { et al. 1985a) }\end{array}$ \\
\hline & & $\begin{array}{l}\text { percentage of bowhead whales diving when approached by } \\
\text { circling Island aircraft at three altitudes (Richardson et al. } \\
\text { 1985a) }\end{array}$ \\
\hline
\end{tabular}




\begin{tabular}{|l|l|l|}
\hline $\begin{array}{l}\text { Assessment } \\
\text { endpoint }\end{array}$ & Type of empirical model & \multicolumn{1}{c|}{ Example } \\
\hline & $\begin{array}{l}\text { effects associated with } \\
\text { ranges of frequencies of } \\
\text { sound }\end{array}$ & $\begin{array}{l}\text { sound frequencies of 500 to 2000 Hz altered white whale } \\
\text { movement (EPA 1980) }\end{array}$ \\
\cline { 2 - 3 } & $\begin{array}{l}\text { response related to } \\
\text { behavior prior to overflight }\end{array}$ & $\begin{array}{l}\text { bowhead whales actively feeding, socializing, or mating are } \\
\text { generally less responsive to aircraft (Richardson et al. 1991) }\end{array}$ \\
\cline { 2 - 3 } & $\begin{array}{l}\text { feeding white whales less affected by helicopters than } \\
\text { swimming animals (Fraker and Fraker 1979) }\end{array}$ \\
\hline plant \\
community & $\begin{array}{l}\text { plant production versus } \\
\text { quantity of soil following } \\
\text { erosion }\end{array}$ & reduction in wheat yield per depth of topsoil (Lyles 1975) \\
\hline surface soil & $\begin{array}{l}\text { erosion versus wind speed } \\
\text { upon helicopter landing or } \\
\text { taking off }\end{array}$ & measurement of soil loss at a particular site \\
\hline
\end{tabular}

${ }^{1}$ Model included alert posture, as well as flight responses.

Sound pressure-response models analogous to dose-response models for chemicals are rare. Typically, if more than a series of sound levels or distances to aircraft are measured concurrently with effects, what is reported is the dominant type of effect that occurs at each exposure (rather than how a single type of effect increases with exposure). Therefore, most empirical models of effects associated with the noise of aircraft overflights are threshold models (Sect. 4.1.3).

In addition to these empirical models, the assessor should seek information that could be used to derive models from natural resource managers at the site of concern, as well as independent agencies who may manage the land below military airspace regions. For example, the U. S. Fish and Wildlife Service found that many field offices, refuges, hatcheries and research centers have information on local responses of wildlife to aircraft noise (Gladwin et al. 1988).

\subsubsection{Mechanistic Models (6.1.2)}

Mechanistic models are simulation models based on an assumed mechanism of action. Parameters of these models are derived from empirical data. The mechanisms of effects of stressors associated with low-altitude overflights are not generally understood well enough to represent in mathematical exposureresponse models, but exceptions exist.

Sound. A simulation model has been developed to determine behavior and weight loss of molting Pacific black brant (Branta bernicla nigricans) due to disturbance by Bell 206 or Bell 412 helicopters (Miller et al. 1994). Variables are distance to aircraft, aircraft type and flock size. The Flight-Line submodel includes as an input the spatial distribution of molting brant. The Behavior-and-Energetics submodel determines lateral distance to each flock, describes behavior of each flock (assumed to act in synchrony), and calculates the weight of brant at the end of molt by calculating the daily energy budget (foraging minus production of new feathers, 9 behaviors, and maintenance).

Collision. The mechanism of mortality from avian collisions with aircraft is well-understood. As soon as the animal is exposed to the aircraft, it may be assumed to be dead. Thus, all that is needed is a good model of exposure (Sect. 3.4). It is unlikely that populations of birds will be affected by bird strikes, because there would be unacceptable levels of aircraft loss before a population would be affected. Thus, significant impacts may only be credible for individuals of threatened or endangered populations. 
Erosion. Another mechanistic model for impacts of overflights is a model for soil erosion due to air movement from aircraft takeoffs and landings. Wind erosion is controlled by 11 primary variables: soil erodibility, knoll erodibility, surface crust stability, soil ridge roughness, wind velocity, surface soil moisture, distance across field, sheltered distance, quantity of vegetative cover, kind of vegetative cover, and orientation of vegetative cover (Woodruff and Siddoway 1965). The Wind Erosion Equation, developed by Woodruff and Siddoway (1965) groups many of these variables:

$$
E=f\left(I^{\prime}, K^{\prime}, C^{\prime}, L^{\prime}, V\right)
$$

where:
$\mathrm{E}^{\prime} \quad=\quad$ Potential average soil loss due to wind erosion (tons/acre/yr)
I' = Erodibility factor. Potential soil loss from wide, unsheltered field with smooth, noncrusted surface, adjusted for windward slopes greater than $150 \mathrm{~m}$. Increases with percentage of soil particles greater than $0.84 \mathrm{~mm}$ diameter (tons/acre/yr).
$\mathrm{K}^{\prime}=$ Ridge roughness factor. Measure of the ratio of ridge height to spacing compared to the 1:4 average (unitless).
$\mathrm{C}^{\prime}=\quad$ Climatic factor. Calculated from average wind velocity, surface soil moisture, and temperature (unitless).
$\mathrm{L}^{\prime} \quad=\quad$ Field length factor. Measure of unsheltered distance across field in direction of prevailing wind (m).
$\mathrm{V}=\quad$ Vegetative cover factor. Measure of the kind, quantity, and orientation of plant cover (tons/acre).

The equation is sometimes expressed as the product of the five variables (e.g. Batie 1983), but the relationships between variables are more complex than that. Woodruff and Siddoway (1965) present a method to solve the function stepwise, and empirically. The equation has been incorporated into computer models in the last few years. Because the function was derived from crop studies, some of the variables are not easily applied to natural vegetation. The extent to which location-specific terms from Woodruff and Siddoway (1965) are used contributes to the uncertainty in the risk assessment. For example, it is not advisable universally to use soil erodibility factors from Garden City, Kansas in the 1950s. If erosion has been measured or modeled previously on the installation, the erodibility factor may be obtained from that effort. Otherwise, an estimate of the erodibility factor may be obtained from the local agricultural college soil science department or extension agent. Lyles (1975) transforms annual soil loss rates (E) to depth of soil loss per year.

It should be noted that the Wind Erosion Equation provides a measure of dislodged soil; the equation provides no estimates of the travel distance of the soil (Batie 1983). Thus, the equation may overestimate the quantity of soil that erodes from the area of interest. Because the light, organic particles are likely to travel farther than other soil particles, fertility is expected to be reduced.

To estimate the distance that the soil has traveled, a simple relationship is recommended. Above $19.3 \mathrm{~km} / \mathrm{h}$, soil movement is proportional to wind velocity, cubed (Brady 1974). Wind speeds of $19.3 \mathrm{~km} / \mathrm{h}$ are required to initiate soil movement (Brady 1974).

Air movement, takeoff and landing. Little information about the impacts of aircraft takeoffs and landings on plant production is available. An exception is a study of the effects of wind on crop plants (Cleugh et al. 1998). Cleugh et al. (1998) provide a mechanistic equation for the drag force on a plant that is associated with wind. The drag force is comprised of form drag (experienced by 3-dimensional bodies) and skin friction, which is exerted tangentially onto the surface of the plant. 


$$
F=U^{2} a c_{d}
$$

$\begin{array}{lll}\text { where: } F & = & \text { drag force }(\mathrm{N}) \\ \mathrm{D} & = & \text { density of air }\left(\mathrm{kg} / \mathrm{m}^{3}\right) \\ \mathrm{U} & = & \text { mean windspeed }(\mathrm{m} / \mathrm{s}) \\ \mathrm{a} & = & \text { area of body exposed to wind }\left(\mathrm{m}^{2}\right) \\ \mathrm{c}_{\mathrm{d}} & = & \text { drag coefficient (unitless) }\end{array}$

The drag coefficient depends on: the shape of the leaf, the orientation of the leaf, the ability of the leaf to change shape at the wind speed, and the extent of leaf fluttering (Cleugh et al. 1998). Drag coefficients for a few crops and deciduous tree foliage are presented in Cleugh et al. (1998). Lodging occurs if the drag force is greater than the shear strength in the rhizosphere soil or the strength of the stem. The latter two quantities are not easy to estimate, but root lodging commonly occurs when soil is moistened by rain or irrigation and stem lodging is most common in dry, hard soil (Cleugh et al. 1998).

\subsubsection{Thresholds (6.1.3)}

Numerous studies and opportunistic observations of low-altitude overflights have been undertaken in the past thirty years that have resulted in empirical effects models, mostly simple thresholds. A threshold is a Lowest Observed Adverse Effects Level (LOAEL). As stated above, an assessment endpoint should include a significant level of effect (e.g., a $20 \%$ decrement in hatchling survival) in its definition; however there is no consensus in the regulatory community about the level of effect that is deemed important. As a practical matter, it is generally impossible to extrapolate from a particular level of effect on a behavioral endpoint to a particular level of effect on reproduction or abundance. Thresholds presented below are extracted from a study if effects were detected at a level of 5\% or above. Exposures at which no effects occurred (No Observed Adverse Effects Levels, NOAELs) are also listed below.

The major stressors for which quantitative threshold models are available are 1) sound and 2) sound and visual stressors, combined (actual studies of overflights). Studies using recorded sound in the laboratory or field have also been performed, but these are not included below if the exposure to continuous sound was for more than a couple of hours. Sound pressure (integrated, average or maximum) is generally believed to be the most useful measure of exposure in these exposure-response models. However, the most frequent measure is distance (altitude, slant distance, or horizontal distance to the flight track). Moreover, distance is sometimes a better predictor of response than aircraft type or sound level (Ward et al. 1999).

Thresholds for which distance is the measure of exposure are most reliable if the aircraft and land cover types of concern are the same as those in the study from which the thresholds were derived, or there is a means to extrapolate from the exposure due to one type of aircraft and ground cover to another. Alternatively, a distribution of LOAELs, i.e., distances from various aircraft, may be described, and the aircraft at the site of concern may be assumed to be a random variate among the aircraft "tested" (Fig. 2). This procedure is recommended only if little is known about how the sound pressure output of the aircraft of concern compares to that of the tested aircraft. Unfortunately, such distributions represent variability in type of aircraft, site conditions, type of effect, level of effect, and species of animal, so these sources of variability should be considered in the risk characterization.

In addition, the assumption must be made that the propagation of sound to the ground or location of the assessment endpoint is equivalent at the site-specific assessment location and at the study location.

Thresholds for the effects of noise are presented in endpoint-specific tables below. These include LOAELs and NOAELs. Because the levels of effects vary, a risk assessor may move some of the LOAELs in these 
tables to the list of NOAELs, if the level of effects for the assessment endpoint is below that agreed to by the site manager for the risk assessment.

The assessor should use species-specific LOAELs and NOAELs where possible. If data were obtained near the installation of interest, those should be used preferentially. The LOAEL of an untested raptor population, for example, may be assumed to be a random variate in the distribution of effects distances among raptors. In Table 14, the overall effects (LOAEL) distribution for raptors in various environments and exposed to overflights of various aircraft would be the distribution of 18 distances. If a single, conservative effects threshold is desired, the ninetieth percentile (or highest value if 10 values or less) of the LOAELs could be used. For raptors, that would be $340 \mathrm{~m}$.

The assessor must determine whether the thresholds in the tables below (or a subset of them) are adequate for his or her purposes. No standards exist for the protection of wildlife from sound or other stressors associated with overflights. It has previously been assumed that standards that are protective of humans would also be protective of wildlife (CHABA 1977).

\subsubsection{Raptors}

Distance and a few sound pressure thresholds for effects on predatory birds are presented in Table 14 and Fig. 2. The mode of the LOAELs for behavioral responses of raptors is $150 \mathrm{~m}$ slant distance from the overflight. A conservative distance is $340 \mathrm{~m}\left(90^{\text {th }}\right.$ percentile of distance thresholds; see above). In a rigorous analysis of published and unpublished raptor effects data, Awbrey and Bowles (1989) found that the mean slant distance associated with flight was between 250 and $300 \mathrm{~m}$. In the same study, the sound level threshold associated with flight was $97 \mathrm{dBA}$. The closest estimate of an effect on abundance or production is the $96 \mathrm{~m}$ slant distance estimate for the threshold distance for a negative impact on prey delivery in owls (Delaney et al. 1999). Distance NOAELs range from about $150 \mathrm{~m}$ to $1000 \mathrm{~m}$ slant distance. Insufficient effects data are available to differentiate between thresholds for rotary-wing aircraft and thresholds for fixed-wing aircraft.

\subsubsection{Waterfowl}

Distance, sound pressure, and disturbance frequency thresholds for effects on waterfowl are presented in Table 15. Birds are commonly disturbed at a distance of greater than a kilometer away; the range of LOAELs is between about $300 \mathrm{~m}$ and about $20 \mathrm{~km}$. A conservative distance effects level is $15 \mathrm{~km}$ (the $23 \mathrm{~km}$ value may be discarded because it is not known whether there was a minimally a 5\% level of effects, see Sect. 4.1.3). The information on distance and behavioral response that was compiled for this framework suggests that shorebirds and other waterfowl are the most sensitive endpoints to overflights, at least in terms of flight behavior. Few other distance LOAELs are over $1 \mathrm{~km}$. None of these LOAELs are direct measures of abundance or production. The single LOAEL related to frequency of disturbance $(2 / \mathrm{hr})$ was associated with abundance of snow geese at the location (Belanger and Bedard 1989). Few NOAELs are available for waterfowl. NOAELs that have been measured at $2 \mathrm{~km}$ are shorter slant distances than some of the LOAELs, which suggests that a reliable NOAEL for waterfowl in general is not available.

\subsubsection{Birds susceptible to bird strikes}

It has been reported that as aircraft velocities exceed $150 \mathrm{~km} / \mathrm{h}$, birds are much less likely to be able to take evasive action from potential collisions (Solman 1981).

\subsubsection{Ungulates}


Distance thresholds for effects on ungulates are presented in Table 16 and Fig. 3. The LOAELs are highly variable, ranging from just over $30 \mathrm{~m}$ to over $1500 \mathrm{~m}$. A conservative $\left(90^{\text {th }}\right.$ percentile) distance effects level is $420 \mathrm{~m}$. (Note that this is calculated using the longest distance if a range is given for the LOAEL in a study in Table 16. Also, where aircraft fly over herds, the altitude is assumed to approximate the slant distance.) Ten percent of ungulate herds or groups would be expected to display behavioral effects at this distance from aircraft. Thresholds for behavioral effects from sound range from 75 to $113 \mathrm{dBA}$. None of the distance LOAELs are direct measures of abundance or production. The only sound threshold that involves the growth of the animal (sheep) uses an exposure with low relevance to overflights (14 days of white noise). Few NOAELs are available, and none are longer distances than the $90^{\text {th }}$ percentile of the LOAEL values.

\subsubsection{Small mammals}

Distance thresholds for effects on small mammals are not available. Sound pressure level thresholds are presented in Table 17. Because the exposure levels are in various units and represent various durations, they are not statistically summarized here. Of the few thresholds that are available, a few are direct measures of abundance and reproduction.

\subsubsection{Reptiles}

Two threshold values are available for the effects of sound on reptiles (Table 18). These are 95 $\mathrm{dBA}$ and $115 \mathrm{dBA}$. Both represent effects on hearing.

\subsubsection{Amphibians}

A single sound pressure level threshold (95 dBA) is available for a single amphibian species (Table 18). The threshold relates to the behavior of the particular toad species tested.

\subsubsection{Pinnipeds}

Distance thresholds for behavioral effects on pinnipeds are presented in Table 19 and Fig. 4. Sound pressure level thresholds are not available. The LOAELs are rather variable, ranging from just over $150 \mathrm{~m}$ to about $2000 \mathrm{~m}$. A conservative $\left(90^{\text {th }}\right.$ percentile) distance effects level is $1150 \mathrm{~m}$. (Note that this is calculated using the longest distance if a range is given for a particular LOAEL in a study in Table 19.) If the pinniped's view is obscured by a cliff, haze or cloud cover, the effective slant distance is probably lower (see below). Most thresholds represent movement away from the overflight. Two secondary sources report population impacts related to stampedes. It is noteworthy that the distribution of sensitivities of walruses to overflights is not appreciably narrower than that of pinnipeds, generally. Thus, these animals would be an ideal choice to represent pinnipeds in a field study of overflights by military aircraft.

The U. S. National Marine Fisheries Service (NMFS) has proposed a "120 decibel" rule as the maximum sound level to which any marine mammal may be exposed (Kastak and Schusterman 1996). The regulatory threshold is based on responses of baleen whales to low-frequency, underwater acoustic sources, but flaws have been associated with the study. This proposed level is likely to be increased to about $180 \mathrm{~dB}$ when the NMFS promulgates the final rule. In a single study, a temporary acoustic threshold shift was observed in a harbor seal (Kastak and Schusterman 1996). The stressor was continuous construction noise at $90-120 \mathrm{~dB}$ sound pressure level, unweighted, which is not closely related to the impulsive sound of aircraft overflights.

\subsubsection{Cetaceans (whales, dolphins) and Sirenians (manatees)}


Distance thresholds for effects on cetaceans and sirenians are presented in Table 20. Distance LOAELs are all altitude values, which range from about $100 \mathrm{~m}$ to $670 \mathrm{~m}$. Because there are only 10 values, the highest distance of $670 \mathrm{~m}$ is chosen as a conservative value. Two sound thresholds are presented, 115 $\mathrm{dB}$ and $120 \mathrm{~dB}$ re $1 \mu \mathrm{Pa}$, but the NOAEL for another low-frequency source is $130 \mathrm{~dB}$. Most thresholds are based on a diving response.

Because of studies by Malme et al. (e.g. Malme et al. 1984), there has been an attempt to establish the $120 \mathrm{~dB}$ level as the threshold of behavioral response of gray whales to industrial noise (Frankel and Clark 1998). The threshold corresponds to 50\% avoidance (Kastak and Schusterman 1996). The U. S. National Marine Fisheries Service has proposed a "120 decibel" rule as the maximum sound level to which any marine mammal may be exposed (Kastak and Schusterman 1996). The regulatory threshold is based on responses of baleen whales to low-frequency, underwater acoustic sources, but flaws have been associated with the study. Additional evidence for this threshold for bowhead whales is provided by Richardson et al. (1990). However, Frankel and Clark (1998) note that the animals may be responding to features of the source of the sound, such as sound gradient or changes in the frequency spectrum rather than to the level itself. The proposed regulatory threshold for sound is likely to be increased to about 180 $\mathrm{dB}$ when the NMFS promulgates the final rule.

\subsubsection{Productivity losses due to soil erosion}

Soil-loss tolerances, also called T-values, are the maximum annual soil losses (threshold values) that can be sustained without adversely affecting productivity (Batie 1983). Soil erosion in quantities greater than T-values is frequently defined as "excess" soil erosion. For soils in the United States, USDA has assigned T-values that usually range from 1-5 tons/acre/yr (3-14 metric tons/ha/yr), depending on soil properties (Batie 1983). The work that has been done to quantify productivity losses associated with wind erosion is for particular crops in well-characterized, tilled soils (Lyles 1975). It is recommended that risk assessors choose a threshold value of 2 tons/ha/yr (if conservatism is desired) or a uniform distribution of from 2 to 12 tons/ha/yr if a probabilistic assessment is performed.

\subsubsection{Productivity losses due to air movement from takeoffs and landings}

Most of the information relating plant growth and damage associated with mechanical stress is not directly related to wind parameters. For example, Turgeon and Webb (1971) compared the growth of Cucurbita melopepo plants subjected to $30 \mathrm{sec}$ of shaking of the petioles and stroking of the leaf blades to plants that were not handled. Lengths and fresh weights of stems and petioles were reduced, but radial growth of petioles was increased. The researchers hypothesized that ethylene was the mechanism of the change.

Plants of the species Capsella bursa-pastoris, a herbaceous dicot, were vibrated for $60 \mathrm{~s}$ at $250 \mathrm{~Hz}$ each day until maturity (Niklas 1998). This exposure resulted in: 1) a 30\% reduction in mature plant height, 2) a $12 \%$ increase in stem diameter, 3) a $15 \%$ increase in root diameter, 4) a delay of anthesis of the last flower by $5 \mathrm{~d}, 5$ ) a delay in maturation of the first fruits by $3 \mathrm{~d}, 6$ ) acceleration of the onset of senescence by $8 \mathrm{~d}$, and 7) $43 \%$ fewer seeds. Associated with the differences in biomass allocation was an increase in the magnitude of root-breaking stress (Niklas 1998).

Thus, thresholds for effects on productivity are not available unless rotor wash velocity or frequency of takeoffs and landings may be related to time of vibration of plants. 
Table 14. Aircraft distance and sound pressure thresholds for effects on raptors.

\begin{tabular}{|c|c|c|c|c|c|c|}
\hline Species & Overflight & LOAEL & NOAEL & Response & location & Reference \\
\hline $\begin{array}{l}\text { Cooper's hawk } \\
\text { (Accipiter } \\
\text { cooperii) }\end{array}$ & $\begin{array}{l}\text { A-4 Skyhawk, A-7 } \\
\text { Corsair II, A-10 } \\
\text { Thunderbolt II, F-4 } \\
\text { Phantom, F-15 Eagle, } \\
\text { and/or F-104 Starfighter }\end{array}$ & & $\begin{array}{l}150 \text { m slant } \\
\text { distance } \\
(\text { dBA-max } \\
\text { between } 89 \\
\text { and 105) } \\
\end{array}$ & $\begin{array}{l}\text { no interruption of high-priority } \\
\text { behavior, protest calls, } \\
\text { cowering or flying out, mid- } \\
\text { nestling stage }\end{array}$ & $\begin{array}{l}\text { most in southern } \\
\text { half of Arizona }\end{array}$ & $\begin{array}{l}\text { Ellis et al. } \\
1991\end{array}$ \\
\hline $\begin{array}{l}\text { Common black } \\
\text { hawk (Buteogallus } \\
\text { anthracinus) }\end{array}$ & $\begin{array}{l}\text { A-4 Skyhawk, A-7 } \\
\text { Corsair II, A-10 } \\
\text { Thunderbolt II, F-4 } \\
\text { Phantom, F-15 Eagle, } \\
\text { and/or F-104 Starfighter }\end{array}$ & & $\begin{array}{l}150 \text { m slant } \\
\text { distance } \\
\text { (dBA-max } \\
\text { between } 89 \\
\text { and 105) }\end{array}$ & $\begin{array}{l}1 / 11(9 \%) \text { late-nestling stage } \\
\text { young bird cowered (crouched), } \\
\text { but none flew out }\end{array}$ & $\begin{array}{l}\text { most in southern } \\
\text { half of Arizona }\end{array}$ & $\begin{array}{l}\text { Ellis et al. } \\
1991\end{array}$ \\
\hline $\begin{array}{l}\text { zone-tailed hawk } \\
\text { (Buteo } \\
\text { albonotatus) }\end{array}$ & $\begin{array}{l}\text { A-4 Skyhawk, A-7 } \\
\text { Corsair II, A-10 } \\
\text { Thunderbolt II, F-4 } \\
\text { Phantom, F-15 Eagle, } \\
\text { and/or F-104 Starfighter }\end{array}$ & $\begin{array}{l}150 \text { m slant } \\
\text { distance (dBA- } \\
\text { max between } 89 \\
\text { and 105) }\end{array}$ & $\begin{array}{l}500 \mathrm{~m} \text { slant } \\
\text { distance }\end{array}$ & $\begin{array}{l}\text { 13/113 (12\%) displayed } \\
\text { significant change in behavior } \\
\text { (interruption of high-priority } \\
\text { behavior, protest calls, } \\
\text { cowering, or flying out); only } \\
\text { late-nestling stage birds } \\
\text { affected }\end{array}$ & $\begin{array}{l}\text { most in southern } \\
\text { half of Arizona }\end{array}$ & $\begin{array}{l}\text { Ellis et al. } \\
1991\end{array}$ \\
\hline $\begin{array}{l}\text { red-tailed hawk } \\
\text { (Buteo } \\
\text { jamaicensis) }\end{array}$ & $\begin{array}{l}\text { A-4 Skyhawk, A-7 } \\
\text { Corsair II, A-10 } \\
\text { Thunderbolt II, F-4 } \\
\text { Phantom, F-15 Eagle, } \\
\text { and/or F-104 Starfighter }\end{array}$ & $\begin{array}{l}150 \text { m slant } \\
\text { distance (dBA- } \\
\text { max between } 89 \\
\text { and 105) }\end{array}$ & $\begin{array}{l}500 \mathrm{~m} \text { slant }^{1} \\
\text { distance }^{1}\end{array}$ & $\begin{array}{l}4 / 78 \text { (5\%) displayed significant } \\
\text { change in behavior (interruption } \\
\text { of high-priority behavior, } \\
\text { protest calls, cowering, or } \\
\text { flying out); only early-nestling } \\
\text { stage adult birds affected }\end{array}$ & $\begin{array}{l}\text { most in southern } \\
\text { half of Arizona }\end{array}$ & $\begin{array}{l}\text { Ellis et al. } \\
1991\end{array}$ \\
\hline $\begin{array}{l}\text { red-tailed hawk } \\
\text { (Buteo } \\
\text { jamaicensis) }\end{array}$ & $\begin{array}{l}\text { single Army UH-1 } \\
\text { helicopter, flew directly } \\
\text { at nests and passed } \\
\text { within } 30 \mathrm{~m}, 45-65 \\
\mathrm{~km} / \mathrm{h} \text {, daytime }\end{array}$ & $\begin{array}{l}100 \mathrm{~m} \text { mean slant } \\
\text { distance, } 30-45 \\
\text { m altitude }\end{array}$ & $\begin{array}{l}500 \mathrm{~m}> \\
\text { slant distance } \\
>100 \mathrm{~m}\end{array}$ & $\begin{array}{l}\text { 9/17 (53\%) flushed (not } \\
\text { previously habituated to } \\
\text { overflights) }\end{array}$ & $\begin{array}{l}\text { Pinyon Canyon } \\
\text { Maneuver Site in } \\
\text { southeastern } \\
\text { Colorado }\end{array}$ & $\begin{array}{l}\text { Andersen et } \\
\text { al. } 1989\end{array}$ \\
\hline $\begin{array}{l}\text { red-tailed hawk } \\
\text { (Buteo } \\
\text { jamaicensis) }\end{array}$ & $\begin{array}{l}\text { single Army UH-1 } \\
\text { helicopter, flew directly } \\
\text { at nests and passed } \\
\text { within } 30 \mathrm{~m}, 45-65\end{array}$ & $\begin{array}{l}10 \mathrm{~m} \text { mean slant } \\
\text { distance, } 30-45 \\
\mathrm{~m} \text { altitude }\end{array}$ & $\begin{array}{l}\text { about } 11 \mathrm{~m} \\
\text { slant distance }\end{array}$ & $\begin{array}{l}1 / 12(8 \%) \text { flushed (previously. } \\
\text { habituated to overflights) }\end{array}$ & $\begin{array}{l}\text { Fort Carson } \\
\text { Military } \\
\text { Reservation in } \\
\text { east Central }\end{array}$ & $\begin{array}{l}\text { Andersen et } \\
\text { al. } 1989\end{array}$ \\
\hline
\end{tabular}


55

\begin{tabular}{|c|c|c|c|c|c|c|}
\hline Species & Overflight & LOAEL & NOAEL & Response & location & Reference \\
\hline & $\mathrm{km} / \mathrm{h}$, daytime & & & & Colorado & \\
\hline $\begin{array}{l}\text { rough-legged hawk } \\
\text { (Buteo lagopus) }\end{array}$ & helicopter & & $\begin{array}{l}150,300 \mathrm{~m} \\
\text { slant distance }\end{array}$ & no flushing of 2 birds from nest & unknown & Platt 1977 \\
\hline $\begin{array}{l}\text { endangered Florida } \\
\text { Everglade kite } \\
\text { (Rostrhamus } \\
\text { sociabilis } \\
\text { plumbeus) } \\
\end{array}$ & $\begin{array}{l}\text { mostly Boeing } 727 \\
\text { aircraft, few Learjets }\end{array}$ & & $\begin{array}{l}230 \mathrm{~m} \\
\text { altitude, over } \\
\text { nesting } \\
\text { island, } 89 \\
\text { dBA } \\
\end{array}$ & no birds took flight & $\begin{array}{l}\text { vicinity of Dade } \\
\text { County Training } \\
\text { jetport, FL }\end{array}$ & $\begin{array}{l}\text { Snyder et al } \\
1978\end{array}$ \\
\hline $\begin{array}{l}\text { golden eagle } \\
\text { (Aquila } \\
\text { chrysaetos) }\end{array}$ & $\begin{array}{l}\text { A-4 Skyhawk, A-7 } \\
\text { Corsair II, A-10 } \\
\text { Thunderbolt II, F-4 } \\
\text { Phantom, F-15 Eagle, } \\
\text { and/or F-104 Starfighter }\end{array}$ & & $\begin{array}{l}150 \text { m slant } \\
\text { distance } \\
\text { (dBA-max } \\
\text { between } 89 \\
\text { and 105) }\end{array}$ & $\begin{array}{l}\text { no interruption of high-priority } \\
\text { behavior, protest calls, } \\
\text { cowering or flying out, mid- } \\
\text { nestling stage }\end{array}$ & $\begin{array}{l}\text { most in southern } \\
\text { half of Arizona }\end{array}$ & $\begin{array}{l}\text { Ellis et al. } \\
1991\end{array}$ \\
\hline $\begin{array}{l}\text { golden eagle } \\
\text { (Aquila } \\
\text { chrysaetos) }\end{array}$ & helicopter & $150 \mathrm{~m}$ & & $1 / 2$ birds flushed from nest & unknown & Platt 1977 \\
\hline $\begin{array}{l}\text { bald eagle } \\
\text { (Haliaeetus } \\
\text { leucocephalus) }\end{array}$ & $\begin{array}{l}\text { UH-1 Huey and OH-58 } \\
\text { Bell helicopters, 35-55 } \\
\mathrm{km} / \mathrm{h}\end{array}$ & $\begin{array}{l}60-120 \mathrm{~m} \\
\text { altitude }\end{array}$ & & $\begin{array}{l}43 \% \text { of adults and } 54 \% \text { of } \\
\text { subadults flushed }\end{array}$ & $\begin{array}{l}\text { Fort Lewis } \\
\text { Army } \\
\text { Reservation, } \\
\text { Washington }\end{array}$ & $\begin{array}{l}\text { Stalmaster } \\
\text { and Kaiser } \\
1997\end{array}$ \\
\hline $\begin{array}{l}\text { bald eagle } \\
\text { (Haliaeetus } \\
\text { leucocephalus) }\end{array}$ & $\begin{array}{l}\text { sample of } 25 \% \text { military } \\
\text { jets, } 51 \% \text { light planes, } \\
24 \% \text { helicopters }\end{array}$ & $\begin{array}{l}400 \mathrm{~m} \text { slant } \\
\text { distance }\end{array}$ & $\begin{array}{l}850 \mathrm{~m} \text { slant } \\
\text { distance }\end{array}$ & $\begin{array}{l}25 \% \text { took flight; helicopters } \\
\text { had highest response }\end{array}$ & $\begin{array}{l}\text { Arizona and } \\
\text { Michigan }\end{array}$ & $\begin{array}{l}\text { Grubb and } \\
\text { Bowerman } \\
1997\end{array}$ \\
\hline $\begin{array}{l}\text { bald eagle } \\
\text { (Haliaeetus } \\
\text { leucocephalus) }\end{array}$ & $\begin{array}{l}\text { Hiller/Soloy UH-12E or } \\
\text { Bell 206-BIII }\end{array}$ & $>120 \mathrm{~m}$ & & $\begin{array}{l}93 \% \text { flushed; \% flushed birds } \\
\text { independent of distance from } \\
<30 \text { to }>120 \mathrm{~m}\end{array}$ & $\begin{array}{l}7 \text { county region } \\
\text { of Puget Sound, } \\
\text { northwestern } \\
\text { Washington }\end{array}$ & $\begin{array}{l}\text { Watson } \\
1993\end{array}$ \\
\hline $\begin{array}{l}\text { bald eagle } \\
\text { (Haliaeetus } \\
\text { leucocephalus) }\end{array}$ & $\begin{array}{l}\text { Cessna fixed wing } \\
\text { aircraft }\end{array}$ & & $\begin{array}{l}20-200 \mathrm{~m} \\
\text { slant distance }\end{array}$ & $\begin{array}{l}\text { no flushing of incubating or } \\
\text { brooding birds }\end{array}$ & $\begin{array}{l}\text { Chippewa } \\
\text { National Forest } \\
\text { in north-central } \\
\text { Minnesota }\end{array}$ & $\begin{array}{l}\text { Fraser et al. } \\
1985\end{array}$ \\
\hline $\begin{array}{l}\text { bald eagle } \\
\text { (Haliaeetus } \\
\text { leucocephalus) }\end{array}$ & $\begin{array}{l}727 \text { jet, } 4 \text { overflights per } \\
\text { day }\end{array}$ & & $\begin{array}{l}>300 \mathrm{~m} \text { slant } \\
\text { distance, } 90- \\
105 \mathrm{~dB}\end{array}$ & $\begin{array}{l}4.5 \% \text { flushing of birds, no } \\
\text { significant changes in density of } \\
\text { eagles }\end{array}$ & Bellingham, WA & $\begin{array}{l}\text { Fleishner } \\
\text { and } \\
\text { Weisberg }\end{array}$ \\
\hline
\end{tabular}




\begin{tabular}{|c|c|c|c|c|c|c|}
\hline Species & Overflight & LOAEL & NOAEL & Response & location & Reference \\
\hline & & & & & & 1986 \\
\hline $\begin{array}{l}\text { prairie falcon } \\
\text { (Falco mexicanus) }\end{array}$ & $\begin{array}{l}\text { A-4 Skyhawk, A-7 } \\
\text { Corsair II, A-10 } \\
\text { Thunderbolt II, F-4 } \\
\text { Phantom, F-15 Eagle, } \\
\text { and/or F-104 Starfighter }\end{array}$ & $\begin{array}{l}150 \mathrm{~m} \text { slant } \\
\text { distance (dBA- } \\
\text { max between } 89 \\
\text { and } 105)\end{array}$ & $\begin{array}{l}500 \mathrm{~m} \text { slant } \\
\text { distance }^{1}\end{array}$ & $\begin{array}{l}\text { 15/194 (8\%) displayed } \\
\text { significant change in behavior } \\
\text { (interruption of high-priority } \\
\text { behavior, protest calls, } \\
\text { cowering, or flying out); only } \\
\text { courtship stage birds affected }\end{array}$ & $\begin{array}{l}\text { most in southern } \\
\text { half of Arizona }\end{array}$ & $\begin{array}{l}\text { Ellis et al. } \\
1991\end{array}$ \\
\hline $\begin{array}{l}\text { prairie falcon } \\
\text { (Falco mexicanus) }\end{array}$ & military aircraft & $\begin{array}{l}150 \mathrm{~m} \text { mean } \\
\text { (about 60-250 } \mathrm{m} \\
\text { range) slant } \\
\text { distance }\end{array}$ & & flight from nest & unknown & $\begin{array}{l}\text { Awbrey and } \\
\text { Bowles } \\
1989\end{array}$ \\
\hline $\begin{array}{l}\text { gyrfalcon (Falco } \\
\text { rusticolus } \\
\text { candicans) }\end{array}$ & Bell 206 helicopter & $1600 \mathrm{~m}$ & & $\begin{array}{l}\text { flight of pre-egg-laying birds } \\
\text { from a single nest, } 1 / 4(25 \%) \\
\text { of overflights }\end{array}$ & & Platt 1977 \\
\hline $\begin{array}{l}\text { gyrfalcon (Falco } \\
\text { rusticolus } \\
\text { candicans) }\end{array}$ & military aircraft & $\begin{array}{l}300 \mathrm{~m} \text { mean } \\
\text { (about } 100-500 \\
\mathrm{~m} \text { range) slant } \\
\text { distance } \\
\end{array}$ & & flight from nest & unknown & $\begin{array}{l}\text { Awbrey and } \\
\text { Bowles } \\
1989\end{array}$ \\
\hline $\begin{array}{l}\text { peregrine falcon } \\
\text { (Falco peregrinus) }\end{array}$ & $\begin{array}{l}\text { A-4 Skyhawk, A-7 } \\
\text { Corsair II, A-10 } \\
\text { Thunderbolt II, F-4 } \\
\text { Phantom, F-15 Eagle, } \\
\text { and/or F-104 Starfighter }\end{array}$ & $\begin{array}{l}150 \mathrm{~m} \text { slant } \\
\text { distance }(\mathrm{dBA}- \\
\text { max between } 89 \\
\text { and } 105)\end{array}$ & $\begin{array}{l}500 \mathrm{~m} \text { slant } \\
\text { distance }\end{array}$ & $\begin{array}{l}\text { 19/37 (51\%) displayed } \\
\text { significant change in behavior } \\
\text { (interruption of high-priority } \\
\text { behavior, protest calls, } \\
\text { cowering, or flying out); mostly } \\
\text { mid-nestling stage birds } \\
\text { affected }\end{array}$ & $\begin{array}{l}\text { most in southern } \\
\text { half of Arizona }\end{array}$ & $\begin{array}{l}\text { Ellis et al. } \\
1991\end{array}$ \\
\hline $\begin{array}{l}\text { peregrine falcon } \\
\text { (Falco peregrinus) }\end{array}$ & $\begin{array}{l}\text { military jets from } 11^{\text {th }} \\
\text { Air Force }\end{array}$ & & $\begin{array}{l}1000 \mathrm{~m} \text { slant } \\
\text { distance }\end{array}$ & $\begin{array}{l}\text { little reaction ( } 8 \text { male birds or } \\
3 \% \text { flight response), minimal } \\
\text { population response, no } \\
\text { detectable difference in rate of } \\
\text { prey brought to nests }\end{array}$ & interior Alaska & $\begin{array}{l}\text { D. Roby } \\
\text { (personal } \\
\text { communicat } \\
\text { ion 3/99) }\end{array}$ \\
\hline $\begin{array}{l}\text { peregrine falcon } \\
\text { (Falco peregrinus) }\end{array}$ & military aircraft & $\begin{array}{l}300 \mathrm{~m} \text { mean } \\
(100-500 \mathrm{~m} \\
\text { range) slant } \\
\text { distance }\end{array}$ & & flight from nest & unknown & $\begin{array}{l}\text { Awbrey and } \\
\text { Bowles } \\
1989\end{array}$ \\
\hline
\end{tabular}




\begin{tabular}{|c|c|c|c|c|c|c|}
\hline Species & Overflight & LOAEL & NOAEL & Response & location & Reference \\
\hline $\begin{array}{l}\text { peregrine falcon } \\
\text { (Falco peregrinus) }\end{array}$ & helicopter & & $\begin{array}{l}150-600 \mathrm{~m} \\
\text { slant distance }\end{array}$ & 0/6 birds flew from nest & unknown & Platt 1977 \\
\hline $\begin{array}{l}\text { peregrine falcon } \\
\text { (Falco peregrinus) }\end{array}$ & $\begin{array}{l}\text { Bell } 206 \text { helicopter or } \\
\text { Cessna } 185\end{array}$ & $\begin{array}{l}105 \mathrm{~m} \text { slant } \\
\text { distance }\end{array}$ & & $\begin{array}{l}5 / 48 \text { birds }(10.4 \%) \text { flushed } \\
\text { from nest }\end{array}$ & unknown & $\begin{array}{l}\text { Windsor } \\
1977\end{array}$ \\
\hline $\begin{array}{l}\text { Mexican spotted } \\
\text { owl (Strix } \\
\text { occidentalis } \\
\text { lucida) }\end{array}$ & $\begin{array}{l}\text { Sikorsky, HH-60G, Pave } \\
\text { hawk, and twin-jet } \\
\text { helicopters, 150-170 } \\
\mathrm{km} / \mathrm{h}\end{array}$ & $\begin{array}{l}61-105 \mathrm{~m} \text { slant } \\
\text { distance (effect } \\
\text { observed at } 89 \mathrm{~m} \text { ) }\end{array}$ & $\begin{array}{l}105 \mathrm{~m} \text { slant } \\
\text { distance, } 104 \\
\text { dBO }(92 \\
\text { dBA) SEL }\end{array}$ & $5 \%$ flush frequency of owls & $\begin{array}{l}\text { Sacramento } \\
\text { Ranger District } \\
\text { of Lincoln } \\
\text { National Forest, } \\
\text { south-central } \\
\text { New Mexico }\end{array}$ & $\begin{array}{l}\text { Delaney et } \\
\text { al. } 1999\end{array}$ \\
\hline $\begin{array}{l}\text { Mexican spotted } \\
\text { owl (Strix } \\
\text { occidentalis } \\
\text { lucida) }\end{array}$ & $\begin{array}{l}\text { Sikorsky, HH-60G, Pave } \\
\text { hawk, and twin-jet } \\
\text { helicopters, 150-170 } \\
\mathrm{km} / \mathrm{h}\end{array}$ & $\begin{array}{l}96 \mathrm{~m} \text { slant } \\
\text { distance }(95 \% \\
\text { prediction } \\
\text { interval between } \\
28 \text { and } 164 \mathrm{~m})\end{array}$ & & $\begin{array}{l}\text { estimated threshold distance for } \\
\text { negative effect on prey delivery } \\
\text { rate }\end{array}$ & $\begin{array}{l}\text { Sacramento } \\
\text { Ranger District } \\
\text { of Lincoln } \\
\text { National Forest, } \\
\text { south-central } \\
\text { New Mexico } \\
\end{array}$ & $\begin{array}{l}\text { Delaney et } \\
\text { al. } 1999\end{array}$ \\
\hline $\begin{array}{l}\text { Mexican spotted } \\
\text { owl (Strix } \\
\text { occidentalis } \\
\text { lucida) }\end{array}$ & $\begin{array}{l}\text { Sikorsky, HH-60G, Pave } \\
\text { hawk, and twin-jet } \\
\text { helicopters, 150-170 } \\
\mathrm{km} / \mathrm{h}\end{array}$ & & $\begin{array}{l}30 \mathrm{~m} \text { slant } \\
\text { distance }\end{array}$ & $\begin{array}{l}\text { no difference in reproductive } \\
\text { success of nests, nest } \\
\text { attentiveness, or number of } \\
\text { female trips from nest }\end{array}$ & $\begin{array}{l}\text { Sacramento } \\
\text { Ranger District } \\
\text { of Lincoln } \\
\text { National Forest, } \\
\text { south-central } \\
\text { New Mexico } \\
\end{array}$ & $\begin{array}{l}\text { Delaney et } \\
\text { al. } 1999\end{array}$ \\
\hline $\begin{array}{l}\text { osprey (Pandion } \\
\text { haliaetus) }\end{array}$ & $\begin{array}{l}\text { CF-18 Hornets with } \\
\text { McDonnell Douglas } \\
\text { with two low-bypass } \\
\text { F404-GE-400 engines, } \\
>2 \text { overflights per day }\end{array}$ & & $\begin{array}{l}1.39 \mathrm{~km} \\
\text { horizontal } \\
\text { distance, } 30 \\
\mathrm{~m} \text { altitude, } \\
100 \mathrm{~dB} \\
\text { maximum } \\
\text { sound } \\
\text { pressure } \\
\text { levels }\end{array}$ & $\begin{array}{l}\text { no startle effect or nest } \\
\text { departure }\end{array}$ & $\begin{array}{l}\text { along Naskaupi } \\
\text { River near } \\
\text { Goose Bay } \\
\text { Labrador, } \\
\text { Canada }\end{array}$ & $\begin{array}{l}\text { Trimper et } \\
\text { al. } 1998\end{array}$ \\
\hline $\begin{array}{l}\text { osprey (Pandion } \\
\text { haliaetus) }\end{array}$ & & $50 \mathrm{~m}$ & & usually flushed & & $\begin{array}{l}\text { Carrier and } \\
\text { Melquist } \\
1976\end{array}$ \\
\hline
\end{tabular}




\begin{tabular}{|l|l|l|l|l|l|l|}
\hline $\begin{array}{l}\text { Species } \\
\text { turkey vulture } \\
\text { (Cathartes } \mathrm{sp} .)\end{array}$ & $\begin{array}{l}\text { Overflight } \\
\text { Bell } 476 \text { helicopter }\end{array}$ & LOAEL & $\begin{array}{l}\text { NOAEL } \\
31-310 \mathrm{~m}, \\
96 \mathrm{dBA}\end{array}$ & $\begin{array}{l}\text { Response } \\
0 / 6 \text { birds flushed }\end{array}$ & $\begin{array}{l}\text { location } \\
\text { unknown }\end{array}$ & $\begin{array}{l}\text { Reference } \\
\text { Edwards et } \\
\text { al. } 1979\end{array}$ \\
\hline
\end{tabular}


Table 15. Thresholds of distance, sound, and disturbance frequency for effects of overflights on waterfowl.

\begin{tabular}{|c|c|c|c|c|c|c|}
\hline Species & Stressor & LOAEL & NOAEL & Response & location & Reference \\
\hline crested tern (Sterna bergii) & $\begin{array}{l}\text { pre-recorded sound from overflight } \\
\text { of DHC-2 Beaver floatplane, } 30-35 \\
\text { sec duration, propeller-generated } \\
\text { frequencies dominant below } 500 \mathrm{~Hz}\end{array}$ & $\begin{array}{l}\text { peak level of } \\
95 \mathrm{~dB}(\mathrm{~A})\end{array}$ & $85 \mathrm{~dB}(\mathrm{~A})$ & $\begin{array}{l}12 \% \text { of } \\
\text { unhabituated } \\
\text { animals startled } \\
\text { (moved from nest } \\
\text { or flapped wings) }\end{array}$ & $\begin{array}{l}\text { Eagle Cay, Great } \\
\text { Barrier Reef } \\
\text { Marine Park }\end{array}$ & $\begin{array}{l}\text { Brown } \\
1990\end{array}$ \\
\hline $\begin{array}{l}\text { Pacific brant (Branta bericla } \\
\text { nigricans) }\end{array}$ & $\begin{array}{l}\text { fixed wing aircraft: single-engine } \\
\text { (Arctic Tern, Piper 150, Cessna } \\
\text { 206, Cessna 185) and twin-engine } \\
\text { (Piper Navajo, Grumman goose, } \\
\text { Twin Otter), } 150-240 \mathrm{~km} / \mathrm{h}\end{array}$ & $\begin{array}{l}400-1100 \mathrm{~m} \\
\text { lateral } \\
\text { distance }\end{array}$ & $\begin{array}{l}\text { about } \\
2000 \mathrm{~m} \\
\text { lateral } \\
\text { distance }\end{array}$ & $\begin{array}{l}22 \% \text { of flocks } \\
\text { took flight }\end{array}$ & $\begin{array}{l}\text { Izembek } \\
\text { Lagoon, Alaska }\end{array}$ & $\begin{array}{l}\text { Ward et al. } \\
1999\end{array}$ \\
\hline $\begin{array}{l}\text { Pacific brant (Branta bericla } \\
\text { nigricans) }\end{array}$ & $\begin{array}{l}\text { rotary wing aircraft: single-engine } \\
\text { (Bell 206-B Jet Ranger, Hughes } \\
500-\mathrm{D}, \text { Bell 205) and twin-engine } \\
(\text { Sikorsky HH-3F), } 150-240 \mathrm{~km} / \mathrm{h}\end{array}$ & $\begin{array}{l}1200-2000 \\
\text { m lateral } \\
\text { distance }\end{array}$ & $\begin{array}{l}\text { about } \\
2000 \mathrm{~m} \\
\text { lateral } \\
\text { distance }\end{array}$ & $\begin{array}{l}28 \% \text { of flocks } \\
\text { took flight }\end{array}$ & $\begin{array}{l}\text { Izembek } \\
\text { Lagoon, Alaska }\end{array}$ & $\begin{array}{l}\text { Ward et al. } \\
1999\end{array}$ \\
\hline $\begin{array}{l}\text { Canada goose (Branta } \\
\text { canadensis taverneri) }\end{array}$ & $\begin{array}{l}\text { fixed wing aircraft: single-engine } \\
\text { (Arctic Tern, Piper 150, Cessna } \\
\text { 206, Cessna 185) and twin-engine } \\
\text { (Piper Navajo, Grumman goose, } \\
\text { Twin Otter), } 150-240 \mathrm{~km} / \mathrm{h}\end{array}$ & $\begin{array}{l}<400-2000 \\
\mathrm{~m} \text { lateral } \\
\text { distance }\end{array}$ & & $\begin{array}{l}5 \% \text { of flocks took } \\
\text { flight }\end{array}$ & $\begin{array}{l}\text { Izembek } \\
\text { Lagoon, Alaska }\end{array}$ & $\begin{array}{l}\text { Ward et al. } \\
1999\end{array}$ \\
\hline $\begin{array}{l}\text { Canada goose (Branta } \\
\text { canadensis taverneri) }\end{array}$ & $\begin{array}{l}\text { rotary wing aircraft: single-engine } \\
\text { (Bell 206-B Jet Ranger, Hughes } \\
500-\mathrm{D} \text {, Bell 205) and twin-engine } \\
(\text { Sikorsky HH-3F), } 150-240 \mathrm{~km} / \mathrm{h}\end{array}$ & $\begin{array}{l}<400-2000 \\
\mathrm{~m} \text { lateral } \\
\text { distance }\end{array}$ & & $\begin{array}{l}11 \% \text { of flocks } \\
\text { took flight }\end{array}$ & $\begin{array}{l}\text { Izembek } \\
\text { Lagoon, Alaska }\end{array}$ & $\begin{array}{l}\text { Ward et al. } \\
1999\end{array}$ \\
\hline $\begin{array}{l}\text { greater snow goose }(\text { Chen } \\
\text { caerulescens atlantica })\end{array}$ & low-flying aircraft & $\begin{array}{l}\text { mean } \\
\text { frequency of } \\
2.0 \\
\text { disturbances } \\
\text { per hour }\end{array}$ & & $\begin{array}{l}\text { number of birds } \\
\text { lower at site the } \\
\text { next day }\end{array}$ & $\begin{array}{l}\text { Montmagny Bird } \\
\text { Sanctuary, } \\
\text { Quebec }\end{array}$ & $\begin{array}{l}\begin{array}{l}\text { Belanger } \\
\text { and Bedard } \\
1989\end{array}\end{array}$ \\
\hline $\begin{array}{l}\text { molting pink-footed goose } \\
\text { (Anser brachyrhynchus) }\end{array}$ & $\begin{array}{l}\text { Bell } 206 \text { helicopter, usu. not } \\
\text { initially visible }\end{array}$ & $\begin{array}{l}6.5 \mathrm{~km},<120 \\
\text { m altitude }\end{array}$ & & $\begin{array}{l}\text { lateral distance } \\
\text { threshold at which } \\
1 / 5 \text { or more flocks } \\
\text { "reacted" }\end{array}$ & $\begin{array}{l}\text { Jameson Land, } \\
\text { east Greenland }\end{array}$ & $\begin{array}{l}\text { Mosbech } \\
\text { and } \\
\text { Glahder } \\
1991\end{array}$ \\
\hline
\end{tabular}




\begin{tabular}{|c|c|c|c|c|c|c|}
\hline Species & Stressor & LOAEL & NOAEL & Response & location & Reference \\
\hline $\begin{array}{l}\text { molting pink-footed goose } \\
\text { (Anser brachyrhynchus) }\end{array}$ & Bell 212 helicopter & $\begin{array}{l}23 \mathrm{~km},<120 \\
\text { m altitude }\end{array}$ & & $\begin{array}{l}\text { lateral distance } \\
\text { threshold at which } \\
1 / 42 \text { or more } \\
\text { flocks "reacted" }\end{array}$ & $\begin{array}{l}\text { Jameson Land, } \\
\text { east Greenland }\end{array}$ & $\begin{array}{l}\text { Mosbech } \\
\text { and } \\
\text { Glahder } \\
1991\end{array}$ \\
\hline $\begin{array}{l}\text { molting barnacle goose } \\
\text { (Branta leucopsis) }\end{array}$ & Bell 206 helicopter & $\begin{array}{l}5 \mathrm{~km},<120 \\
\mathrm{~m} \text { altitude }\end{array}$ & & $\begin{array}{l}\text { lateral distance } \\
\text { threshold at which } \\
1 / 31 \text { or more } \\
\text { flocks "reacted" }\end{array}$ & $\begin{array}{l}\text { Jameson Land, } \\
\text { east Greenland }\end{array}$ & $\begin{array}{l}\text { Mosbech } \\
\text { and } \\
\text { Glahder } \\
1991\end{array}$ \\
\hline $\begin{array}{l}\text { molting barnacle goose } \\
\text { (Branta leucopsis) }\end{array}$ & Bell 212 helicopter & $\begin{array}{l}15 \mathrm{~km},<120 \\
\text { m altitude }\end{array}$ & & $\begin{array}{l}\text { lateral distance } \\
\text { threshold at which } \\
1 / 12 \text { or more } \\
\text { flocks "reacted" }\end{array}$ & $\begin{array}{l}\text { Jameson Land, } \\
\text { east Greenland }\end{array}$ & $\begin{array}{l}\text { Mosbech } \\
\text { and } \\
\text { Glahder } \\
1991\end{array}$ \\
\hline $\begin{array}{l}\text { wintering dark-bellied brent } \\
\text { goose (Branta bernicla } \\
\text { bernicla) }\end{array}$ & $\begin{array}{l}\text { various nonmilitary airplanes and } \\
\text { helicopters }\end{array}$ & $\begin{array}{l}500 \mathrm{~m} \\
\text { altitude, } 1.5 \\
\text { km lateral } \\
\text { distance }\end{array}$ & & $\begin{array}{l}\text { frequent flight } \\
\text { response; "panic" } \\
\text { caused by } \\
\text { helicopters }\end{array}$ & $\begin{array}{l}\text { coastline in } \\
\text { Essex, England }\end{array}$ & $\begin{array}{l}\text { Owens } \\
1977\end{array}$ \\
\hline $\begin{array}{l}\text { ring-necked duck, coot, } \\
\text { gadwall, purple gallinule, } \\
\text { pintail duck }\end{array}$ & helicopter & $\begin{array}{l}\text { about } 300 \mathrm{~m} \\
\text { slant distance }\end{array}$ & & flight response & $\begin{array}{l}\text { Aransas National } \\
\text { Wildlife Refuge, } \\
\text { TX }\end{array}$ & $\begin{array}{l}\text { Edwards et } \\
\text { al. } 1979\end{array}$ \\
\hline $\begin{array}{l}\text { herring gull (Larus } \\
\text { argentatus) habituated to } \\
\text { aircraft takeoffs and landings }\end{array}$ & Boeing 707s, 727s, and 747s & & $101 \mathrm{dBA}$ & $\begin{array}{l}\text { number of nesting } \\
\text { birds flying over } \\
\text { area was not } \\
\text { different from } \\
\text { non-aircraft } \\
\text { conditions }\end{array}$ & $\begin{array}{l}\text { Jamaica Bay } \\
\text { National } \\
\text { Recreation Area, } \\
2 \text { km from } \\
\text { Kennedy } \\
\text { International } \\
\text { Airport }\end{array}$ & $\begin{array}{l}\text { Burger } \\
1981\end{array}$ \\
\hline $\begin{array}{l}\text { mixed colony of fulmars } \\
\text { (Fulmaris glacialis), shags } \\
\text { (Phalacrocorax aristotelis), } \\
\text { herring gulls (Larus } \\
\text { argentatus), kitiwakes (Rissa } \\
\text { tridactyla), guillemots (Uria } \\
\text { aalge), razorbills (Alca } \\
\text { torda), and puffins } \\
\text { (Fratercula arctica) }\end{array}$ & $\begin{array}{l}\text { Sikorsky S61 helicopter or Piper } \\
\text { Aztec (twin-engine) }\end{array}$ & & $\begin{array}{l}100 \mathrm{~m} \\
\text { above } \\
\text { cliff top } \\
\text { (and } \\
\text { above } \\
\text { birds) and } \\
150 \mathrm{~m} \\
\text { above sea } \\
\text { level }\end{array}$ & $\begin{array}{l}\text { attendance of } \\
\text { incubating and } \\
\text { brooding birds not } \\
\text { affected (too few } \\
\text { puffins and } \\
\text { fulmars for } \\
\text { conclusive results } \\
\text { for those species) }\end{array}$ & $\begin{array}{l}\text { Buchan Cliffs, } \\
40 \mathrm{~km} \text { north of } \\
\text { Aberdeen, } \\
\text { Scotland } \\
\text { monoplane) }\end{array}$ & $\begin{array}{l}\text { Dunnet } \\
1977\end{array}$ \\
\hline
\end{tabular}


61

\begin{tabular}{|c|c|c|c|c|c|c|}
\hline Species & Stressor & LOAEL & NOAEL & Response & location & Reference \\
\hline $\begin{array}{l}\text { colonies of great egrets } \\
\text { (Casmer-odius albus), snowy } \\
\text { egrets (Egretta thula, } \\
\text { Louisiana herons } \\
\text { (Hydranassa tricolor), } \\
\text { double-crested cormorants } \\
\text { (Phalacrocorax auritus), } \\
\text { wood storks (Mycteria } \\
\text { americana), and others }\end{array}$ & $\begin{array}{l}\text { Lake single engine amphibian and } \\
\text { Bell 47G-2 }\end{array}$ & & $\begin{array}{l}60 \mathrm{~m} \\
\text { altitude }\end{array}$ & $\begin{array}{l}\text { no bird left the } \\
\text { nest and failed to } \\
\text { return within } 5 \\
\text { min; } 5 \% \text { of birds } \\
\text { left next for } \\
\text { average of } 1.4 \text { min }\end{array}$ & southern Florida & $\begin{array}{l}\text { Kushlan } \\
1979\end{array}$ \\
\hline
\end{tabular}


62

Table 16. Aircraft distance thresholds for effects on ungulates.

\begin{tabular}{|c|c|c|c|c|c|c|}
\hline Species & Stressor & LOAEL & NOAEL & Response & location & Reference \\
\hline $\begin{array}{l}\text { mountain goat } \\
\text { (Oreamnos } \\
\text { americanus) }\end{array}$ & $\begin{array}{l}\text { Bell-212 twin engine } \\
\text { and Bell-206B turbo } \\
\text { helicopter }\end{array}$ & $\begin{array}{l}>1500 \mathrm{~m} \\
\text { horizontal } \\
\text { distance }\end{array}$ & & $\begin{array}{l}37 \% \text { of flights caused at least } \\
\text { moderate group reaction (movement } \\
\text { of } 10-100 \mathrm{~m} \text { or alertness between } 2 \\
\text { and } 10 \text { min, over } 50 \% \text { of animals) }\end{array}$ & $\begin{array}{l}\text { Caw Ridge, } \\
\text { Alberta }\end{array}$ & Côté 1996 \\
\hline $\begin{array}{l}\text { desert mule deer } \\
\text { (Odocoileus } \\
\text { hemionus crooki) }\end{array}$ & $\begin{array}{l}\text { Cessna 172, Cessna } \\
182 \text { or Maule (M-5- } \\
\text { 235C) }\end{array}$ & & $\begin{array}{l}<50 \mathrm{~m} \\
\text { altitude }\end{array}$ & animals did not change habitat & $\begin{array}{l}\text { Picacho } \\
\text { Mountains, } \\
\text { south-central } \\
\text { Arizona }\end{array}$ & $\begin{array}{l}\text { Krausman et al. } \\
1986\end{array}$ \\
\hline $\begin{array}{l}\text { mountain sheep } \\
\text { (Ovis canadensis) }\end{array}$ & $\begin{array}{l}\text { F-16 aircraft, } 90 \% \\
\text { power setting }\end{array}$ & & $\begin{array}{l}125 \mathrm{~m} \\
\text { above } \\
\text { ground } \\
\text { level, } 85 \text { to } \\
110 \mathrm{~dB}\end{array}$ & no altered behavior & $\begin{array}{l}\text { Desert } \\
\text { National } \\
\text { Wildlife } \\
\text { Refuge, } \\
\text { Nevada }\end{array}$ & $\begin{array}{l}\text { Krausman et al. } \\
1998\end{array}$ \\
\hline $\begin{array}{l}\text { mountain sheep } \\
\text { (Ovis canadensis) }\end{array}$ & Cessna 172 or 182 & $>100 \mathrm{~m}$ & & $\begin{array}{l}23 \% \text { of sheep moved up to } 100 \mathrm{~m} \text { and } \\
\text { continued their pre-survey activities }\end{array}$ & & $\begin{array}{l}\text { Krausman and } \\
\text { Hervert } 1983\end{array}$ \\
\hline $\begin{array}{l}\text { mountain sheep } \\
\text { (Ovis canadensis) }\end{array}$ & $\begin{array}{l}\text { helicopter surveys, } \\
\text { sampling intensity } 0.8 \\
\mathrm{~min} / \mathrm{km}^{2} \text { or } 2.0 \\
\mathrm{~min} / \mathrm{km}^{2}\end{array}$ & $50-200 \mathrm{~m}$ & & $\begin{array}{l}\text { moved } 2.5 \text { times farther the day } \\
\text { following survey than previous day; } \\
35-52 \% \text { of animals changed polygons } \\
\text { (8-83 } \mathrm{km} 2 \text { ) following sampling, } \\
\text { compared to } 11 \% \text { day before }\end{array}$ & $\begin{array}{l}\text { San } \\
\text { Bernardino } \\
\text { County, } \\
\text { California }\end{array}$ & $\begin{array}{l}\text { Bleich et al. } \\
1990\end{array}$ \\
\hline $\begin{array}{l}\text { mountain sheep } \\
\text { (Ovis canadensis) }\end{array}$ & $\begin{array}{l}\text { Bell 206B-III turbine } \\
\text { powered helicopter }\end{array}$ & $\begin{array}{l}100 \mathrm{~m} \text { above } \\
\text { ground level }\end{array}$ & & $\begin{array}{l}\text { about } 33-47 \% \text { more animals changed } \\
\text { their use of vegetation types } \\
\text { following overflights; about } 20-45 \% \\
\text { more animals changed sampling } \\
\text { blocks following overflights }\end{array}$ & $\begin{array}{l}\text { San } \\
\text { Bernardino } \\
\text { County, } \\
\text { California }\end{array}$ & $\begin{array}{l}\text { Bleich et al. } \\
1994\end{array}$ \\
\hline $\begin{array}{l}\text { mountain sheep } \\
\text { (Ovis canadensis) }\end{array}$ & $\begin{array}{l}\text { Bell 206B-III turbine } \\
\text { powered helicopter }\end{array}$ & $\begin{array}{l}100 \mathrm{~m} \text { above } \\
\text { ground level }\end{array}$ & & $\begin{array}{l}\text { female mountain sheep moved farther } \\
\text { the day of the survey than other days } \\
\text { in spring, summer, and fall, but not in } \\
\text { winter }\end{array}$ & $\begin{array}{l}\text { San } \\
\text { Bernardino } \\
\text { County, } \\
\text { California } \\
\end{array}$ & $\begin{array}{l}\text { Bleich et al. } \\
1994\end{array}$ \\
\hline $\begin{array}{l}\text { desert bighorn } \\
\text { sheep (Ovis } \\
\text { canadensis } \\
\text { nelsoni) }\end{array}$ & helicopters & $\begin{array}{l}250-450 \mathrm{~m} \\
\text { slant distance }\end{array}$ & & $\begin{array}{l}\text { reduction in foraging efficiency; } \\
\text { effect may only exist in winter }\end{array}$ & $\begin{array}{l}\text { Grand Canyon } \\
\text { National Park }\end{array}$ & $\begin{array}{l}\text { Stockwell et al. } \\
1991\end{array}$ \\
\hline
\end{tabular}




\begin{tabular}{|c|c|c|c|c|c|c|}
\hline Species & Stressor & LOAEL & NOAEL & Response & location & Reference \\
\hline pronghorn antelope & OH-58 helicopter & $\begin{array}{l}150 \mathrm{~m} \text { slant } \\
\text { distance, } 46 \mathrm{~m} \\
\text { altitude, } 77 \\
\text { dBA }\end{array}$ & $\begin{array}{l}120 \mathrm{~m} \\
\text { altitude, } \\
\text { slant range } \\
900 \mathrm{~m}(60 \\
\mathrm{dBA})\end{array}$ & running & $\begin{array}{l}\text { Otero Mesa in } \\
\text { southern New } \\
\text { Mexico }\end{array}$ & $\begin{array}{l}\text { Luz and Smith } \\
1976\end{array}$ \\
\hline moose & fixed-wing aircraft & $60 \mathrm{~m}$ altitude & & "frightened" & & EPA 1980 \\
\hline $\begin{array}{l}\text { woodland caribou } \\
\text { (Rangifer } \\
\text { tarandus caribou) }\end{array}$ & $\begin{array}{l}\text { F-4, F-5, F-16, F-18, } \\
\text { Tornado fixed wing } \\
\text { aircraft, 775-825 km/h }\end{array}$ & $\begin{array}{l}300 \mathrm{~m} \\
\text { altitude, } 70 \mathrm{~m} \\
\text { horizontal } \\
\text { distance }\end{array}$ & & $\begin{array}{l}30 \% \text { response (daily activity level or } \\
\text { daily distance traveled) }\end{array}$ & $\begin{array}{l}\text { Canadian } \\
\text { Forces Base, } \\
\text { Goose Bay }\end{array}$ & $\begin{array}{l}\text { Harrington and } \\
\text { Veitch } 1991\end{array}$ \\
\hline $\begin{array}{l}\text { woodland caribou } \\
\text { (Rangifer } \\
\text { tarandus caribou) }\end{array}$ & F-16 fixed-wing & $\begin{array}{l}25-60 \mathrm{~m} \\
\text { altitude }\end{array}$ & & $\begin{array}{l}15-50 \% \text { response (movement several } \\
\text { meters after pass) }\end{array}$ & $\begin{array}{l}\text { Canadian } \\
\text { Forces Base, } \\
\text { Goose Bay }\end{array}$ & $\begin{array}{l}\text { Harrington and } \\
\text { Veitch } 1991\end{array}$ \\
\hline $\begin{array}{l}\text { woodland caribou } \\
\text { (Rangifer } \\
\text { tarandus caribou) }\end{array}$ & Bell 206L helicopter & $30 \mathrm{~m}$ altitude & & $\begin{array}{l}\text { movement of } 100 \% \text { of individuals } \\
\text { away from helicopter's path, prior to } \\
\text { passing }\end{array}$ & $\begin{array}{l}\text { Canadian } \\
\text { Forces Base, } \\
\text { Goose Bay }\end{array}$ & $\begin{array}{l}\text { Harrington and } \\
\text { Veitch } 1991\end{array}$ \\
\hline $\begin{array}{l}\text { woodland caribou } \\
\text { (Rangifer } \\
\text { tarandus caribou) }\end{array}$ & $\begin{array}{l}\text { A-star 300D } \\
\text { helicopter }\end{array}$ & $\begin{array}{l}30-150 \mathrm{~m} \\
\text { altitude }\end{array}$ & & $\begin{array}{l}\text { movement away from helicopter path } \\
\text { prior to passing }\end{array}$ & $\begin{array}{l}\text { Canadian } \\
\text { Forces Base, } \\
\text { Goose Bay }\end{array}$ & $\begin{array}{l}\text { Harrington and } \\
\text { Veitch } 1991\end{array}$ \\
\hline $\begin{array}{l}\text { Peary caribou } \\
\text { (Rangifer } \\
\text { tarandus pearyi) }\end{array}$ & Bell 206B helicopter & $\begin{array}{l}301-400 \mathrm{~m} \\
\text { altitude }\end{array}$ & & $\begin{array}{l}\text { trotting or galloping by } 29.3 \% \text { of } \\
\text { animals }\end{array}$ & $\begin{array}{l}\text { Prince of } \\
\text { Wales Island }\end{array}$ & $\begin{array}{l}\text { Miller and } \\
\text { Gunn } 1979\end{array}$ \\
\hline $\begin{array}{l}\text { barren-ground } \\
\text { caribou (Rangifer } \\
\text { tarandus) }\end{array}$ & jet turbine helicopters & $150 \mathrm{~m}$ & $\begin{array}{l}\text { about } 300 \\
\mathrm{~m}\end{array}$ & $\begin{array}{l}10 \% \text { to } 25 \% \text { of groups exhibited at } \\
\text { least a mild escape response }\end{array}$ & $\begin{array}{l}\text { northern } \\
\text { Yukon and } \\
\text { Alaska }\end{array}$ & $\begin{array}{l}\text { Calef et al. } \\
1976\end{array}$ \\
\hline $\begin{array}{l}\text { barren-ground } \\
\text { caribou (Rangifer } \\
\text { tarandus) }\end{array}$ & fixed wing aircraft & $150 \mathrm{~m}$ & about $300 \mathrm{~m}$ & $\begin{array}{l}65 \% \text { to } 75 \% \text { of groups exhibited at } \\
\text { least a mild escape response }\end{array}$ & $\begin{array}{l}\text { northern } \\
\text { Yukon and } \\
\text { Alaska }\end{array}$ & $\begin{array}{l}\text { Calef et al. } \\
1976\end{array}$ \\
\hline caribou & helicopter & $150-300 \mathrm{~m}$ & & 30000 animals "fled" & & $\begin{array}{l}\text { Jakimchuk et } \\
\text { al. } 1974\end{array}$ \\
\hline
\end{tabular}


64

\begin{tabular}{|c|c|c|c|c|c|c|}
\hline Species & Stressor & LOAEL & NOAEL & Response & location & Reference \\
\hline muskox & Bell 206B helicopter & $301-400 \mathrm{~m}$ & & $32 \%$ trotting or galloping & & $\begin{array}{l}\text { Miller and } \\
\text { Gunn } 1979 \\
\end{array}$ \\
\hline $\begin{array}{l}\text { non-habituated } \\
\text { horse }\end{array}$ & $\begin{array}{l}\text { simulated F-4 aircraft } \\
\text { noise }\end{array}$ & $\begin{array}{l}113.4 \mathrm{~dB} \text { max, } \\
112.2 \text { SEL } 4 \\
\text { exposures per } \\
\text { day }\end{array}$ & & $\begin{array}{l}\text { all horses (pregnant mares) exhibited } \\
\text { flight posture (highly elevated head, } \\
\text { wide open eye lids, dilated nostrils, } \\
\text { quick forward or sideways } \\
\text { movement) and movement of horses } \\
\text { was significantly higher in treatment } \\
\text { group }\end{array}$ & barn & $\begin{array}{l}\text { LeBlanc et al. } \\
1991\end{array}$ \\
\hline habituated horse & $\begin{array}{l}\text { simulated F-4 aircraft } \\
\text { noise }\end{array}$ & & $\begin{array}{l}113.4 \mathrm{~dB} \\
\text { max, } 112.2 \\
\text { SEL } 6 \\
\text { events per } \\
\text { hour } \\
\end{array}$ & $\begin{array}{l}\text { no horses (pregnant mares) exhibited } \\
\text { more than an alert or irritated } \\
\text { posture; no horses had elevated } \\
\text { cortisol levels }\end{array}$ & barn & $\begin{array}{l}\text { LeBlanc et al. } \\
1991\end{array}$ \\
\hline $\begin{array}{l}\text { non-habituated } \\
\text { horse }\end{array}$ & $\begin{array}{l}\text { simulated F-4 aircraft } \\
\text { noise }\end{array}$ & $\begin{array}{l}\text { 113.4 dB max, } \\
112.2 \text { SEL } 4 \\
\text { exposures per } \\
\text { day }\end{array}$ & & $\begin{array}{l}38 \% \text { of horses (pregnant mares) had } \\
\text { mild heart rate increases sustained } \\
\text { for } 20 \mathrm{sec}\end{array}$ & barn & $\begin{array}{l}\text { LeBlanc et al. } \\
1991\end{array}$ \\
\hline $\begin{array}{l}\text { non-habituated } \\
\text { horse }\end{array}$ & $\begin{array}{l}\text { simulated F-4 aircraft } \\
\text { noise }\end{array}$ & $\begin{array}{l}\text { 113.4 dB max, } \\
112.2 \text { SEL } 4 \\
\text { exposures per } \\
\text { day }\end{array}$ & & $\begin{array}{l}\text { cortisol elevated in } 3 \text { of } 8 \text { tested } \\
\text { mares }\end{array}$ & barn & $\begin{array}{l}\text { LeBlanc et al. } \\
1991\end{array}$ \\
\hline lamb & $\begin{array}{l}\text { USA Standard Institute } \\
\text { White Noise (USASI) }\end{array}$ & $100 \mathrm{~dB}$ & $75 \mathrm{~dB}$ & $\begin{array}{l}\text { increase in heart rate of lamb not } \\
\text { acclimated to sound }\end{array}$ & & Aames 1978 \\
\hline lamb & $\begin{array}{l}\text { USA Standard Institute } \\
\text { White Noise (USASI) }\end{array}$ & & $100 \mathrm{~dB}$ & $\begin{array}{l}\text { no increase in heart rate of lamb } \\
\text { acclimated to sound }\end{array}$ & & Aames 1978 \\
\hline sheep & $\begin{array}{l}\text { USA Standard Institute } \\
\text { (USASI) White Noise }\end{array}$ & $\begin{array}{l}75 \mathrm{~dB}, \\
\text { continuous for } \\
14 \text { days }\end{array}$ & & $\begin{array}{l}\text { lower dry matter intake (only } 2 \% \\
\text { difference) }\end{array}$ & laboratory & $\begin{array}{l}\text { Harbers et al. } \\
1975\end{array}$ \\
\hline
\end{tabular}




\section{5}

Table 17. Sound pressure level thresholds for effects on small mammals.

\begin{tabular}{|c|c|c|c|c|c|c|}
\hline Species & Stressor & LOAEL & NOAEL & Response & location & Reference \\
\hline $\begin{array}{l}\text { feral house mice (Mus } \\
\text { musculus) }\end{array}$ & airport noise & $\begin{array}{l}\text { average noise of incoming } \\
\text { and outgoing aircraft: } 110 \\
\mathrm{~dB}^{1}\end{array}$ & & $\begin{array}{l}\text { increase in adrenal } \\
\text { gland mass }\end{array}$ & $\begin{array}{l}\text { fields near } \\
\text { Memphis } \\
\text { International } \\
\text { Airport }\end{array}$ & $\begin{array}{l}\text { Chesser et } \\
\text { al. (1975) }\end{array}$ \\
\hline mice & $\begin{array}{l}\text { Parisian subway } \\
\text { noise, recording } \\
\text { played for } 1 \text { hour } 4 x \\
\text { per day }\end{array}$ & $105 \mathrm{~dB}^{1}$ & & $\begin{array}{l}\text { higher mortality pre- } \\
\text { weaning, irregular } \\
\text { intervals between } \\
\text { litter production, } \\
\text { slight effect on } \\
\text { weight of pups }\end{array}$ & & $\begin{array}{l}\text { Busnel and } \\
\text { Molin } \\
\text { (1978) }\end{array}$ \\
\hline $\begin{array}{l}\text { heteromyid rodent populations } \\
\text { Merriam's kangaroo rat } \\
\text { (Dipodomys merriami), } \\
\text { Arizona pocket mouse } \\
\text { (Perognathus amplus), desert } \\
\text { pocket mouse (Chaetodipus } \\
\text { penicillatus), white-throated } \\
\text { wood rat (Neotoma albigula), } \\
\text { southern grasshopper mouse } \\
\text { (Onychomys torridus) }\end{array}$ & $\begin{array}{l}\text { military jets, } \\
\text { primarily F-15 } \\
\text { Eagle, F-16 Falcon, } \\
\text { A-10 Warthog (also } \\
\text { somewhat different } \\
\text { habitats in exposed } \\
\text { and control areas) }\end{array}$ & $\begin{array}{l}\text { mean \# flights above } 80 \\
\text { dBA-30.2/day; mean \# } \\
\text { flights above } 100 \\
\text { dBA-4.2/day average } \\
\text { maximum daily level from } \\
\text { each site } 68.8 \mathrm{dBA} \text {; highest } \\
\text { SEL in area } 115.5 \mathrm{dBA}, \\
\text { where aircraft climbed } \\
\text { rapidly }\end{array}$ & & $\begin{array}{l}47 \% \text { mean length of } \\
\text { time on study plots, } \\
\text { decrease of } 4 \text { to } 7 \% \\
\text { survival rate } \\
\text { (including losses due } \\
\text { to dispersal) }\end{array}$ & $\begin{array}{l}\text { under training } \\
\text { racetracks of } \\
\text { Barry M. } \\
\text { Goldwater } \\
\text { Air Force } \\
\text { Range, south- } \\
\text { Central } \\
\text { Arizona }\end{array}$ & $\begin{array}{l}\text { McClenagh } \\
\text { an and } \\
\text { Bowles } \\
(1995)\end{array}$ \\
\hline $\begin{array}{l}\text { Merriam's kangaroo rat } \\
\text { (Dipodomys merriami) }\end{array}$ & $\begin{array}{l}\text { military jets, } \\
\text { primarily F-15 } \\
\text { Eagle, F-16 Falcon, } \\
\text { A-10 Warthog (also } \\
\text { somewhat different } \\
\text { habitats in exposed } \\
\text { and control areas) }\end{array}$ & $\begin{array}{l}\text { mean \# flights above } 80 \\
\text { dBA-- } 30.2 / \text { day; mean \# } \\
\text { flights above } 100 \mathrm{dBA}-- \\
\text { 4.2/day average maximum } \\
\text { daily level from each site } \\
68.8 \mathrm{dBA} \text {; highest ASEL in } \\
\text { area } 115.5 \mathrm{dBA} \text {, where } \\
\text { aircraft climbed rapidly }\end{array}$ & & $\begin{array}{l}\text { hearing threshold ( } 3 \\
\text { dB difference from } \\
\text { control); may be due } \\
\text { to differences among } \\
\text { individuals }\end{array}$ & $\begin{array}{l}\text { under training } \\
\text { racetracks of } \\
\text { Barry M. } \\
\text { Goldwater } \\
\text { Air Force } \\
\text { Range, south- } \\
\text { Central } \\
\text { Arizona }\end{array}$ & $\begin{array}{l}\text { Francine } \\
\text { and Bowles } \\
\text { (1995) }\end{array}$ \\
\hline
\end{tabular}


66

\begin{tabular}{|c|c|c|c|c|c|c|}
\hline Species & Stressor & LOAEL & NOAEL & Response & location & Reference \\
\hline kangaroo rats (Dipodomys spp.) & $\begin{array}{l}\text { military jets, } \\
\text { primarily F-15 } \\
\text { Eagle, F-16 Falcon, } \\
\text { A-10 Warthog }\end{array}$ & & $\begin{array}{l}\text { SEL }>10 \\
\text { OdBA }\end{array}$ & $\begin{array}{l}\text { no significant } \\
\text { differences in } \\
\text { diversity or } \\
\text { abundance of small } \\
\text { mammals }\end{array}$ & \begin{tabular}{|l|} 
on the Barry \\
M. Goldwater \\
Air Force \\
Range, south- \\
Central \\
Arizona \\
\end{tabular} & $\begin{array}{l}\text { Bowles et } \\
\text { al. } 1993\end{array}$ \\
\hline $\begin{array}{l}\text { desert kangaroo rat } \\
\text { (Dipodomys deserti) }\end{array}$ & $\begin{array}{l}\text { recorded dune } \\
\text { buggy sounds, } \\
\text { frequency range } \\
\text { from } 0.085 \text { to } 8.0 \\
\mathrm{kHz} \text { with high } \\
\text { energy below } 2.0 \\
\mathrm{kHz}\end{array}$ & $95 \mathrm{dBA}, 8.5$ min duration & & $\begin{array}{l}\text { temporary threshold } \\
\text { shift in behavioral } \\
\text { hearing sensitivity; } \\
10 \text { min after } \\
\text { exposure, } 2 \text { of } 2 \\
\text { tested animals did } \\
\text { not kick sand when } \\
\text { recordings of } \\
\text { sidewinder ( Crotalus } \\
\text { cerastes) crawls } \\
\text { were played; } 21 \text { days } \\
\text { required for recovery }\end{array}$ & $\begin{array}{l}\text { trapped in } \\
\text { Riverside } \\
\text { County, CA }\end{array}$ & $\begin{array}{l}\text { Brattstrom } \\
\text { and } \\
\text { Bondello } \\
1983\end{array}$ \\
\hline $\begin{array}{l}\text { desert kangaroo rat } \\
\text { (Dipodomys deserti) }\end{array}$ & $\begin{array}{l}\text { recorded dune } \\
\text { buggy sounds, } \\
\text { frequency range } \\
\text { from } 0.085 \text { to } 8.0 \\
\mathrm{kHz} \text { with high } \\
\text { energy below } 2.0 \\
\mathrm{kHz}\end{array}$ & $95 \mathrm{dBA}, 8.5$ min duration & & $\begin{array}{l}\text { ran in circles, } \\
\text { defecated, pushed at } \\
\text { openings of cages, } \\
\text { chewed on cages, } \\
\text { frantically groomed } \\
\text { themselves, } \\
\text { performed repeated } \\
\text { slides, shivered on } \\
\text { hind limbs } \\
\end{array}$ & $\begin{array}{l}\text { trapped in } \\
\text { Riverside } \\
\text { County, CA }\end{array}$ & $\begin{array}{l}\text { Brattstrom } \\
\text { and } \\
\text { Bondello } \\
1983\end{array}$ \\
\hline
\end{tabular}

${ }^{1}$ Assumed to be unweighted decibels. 
Table 18. Sound thresholds for effects on reptiles and amphibians.

\begin{tabular}{|c|c|c|c|c|c|}
\hline Species & Stressor & LOAEL & NOAEL & Response & Reference \\
\hline $\begin{array}{l}\text { Couch's spadefoot toad } \\
\text { (Scaphiopus couchi) }\end{array}$ & $\begin{array}{l}\text { amplified, recorded } \\
\text { motorcycle noise }\end{array}$ & $95 \mathrm{~dB}(\mathrm{~A})$ & & $\begin{array}{l}\text { emergence from burrows ( } 5 \text { to } 35 \% \text { after } 10 \mathrm{~min} \\
\text { exposure, } 20 \text { to } 55 \% \text { after } 20 \mathrm{~min} \text { exposure, } 30 \text { to } \\
60 \% \text { after } 30 \mathrm{~min} \text { exposure) }\end{array}$ & $\begin{array}{l}\text { Brattstrom and } \\
\text { Bondello } 1983\end{array}$ \\
\hline $\begin{array}{l}\text { Desert tortoise } \\
\text { (Gopherus agassizii) }\end{array}$ & $\begin{array}{l}\text { recorded sound } \\
\text { from Air Force } \\
\text { aircraft, } 20 \\
\text { exposures of } 40 \\
\text { min separated by } 2 \\
\text { or more hr }\end{array}$ & $\begin{array}{l}\text { 94.6-114.2 } \\
\text { dB CSEL }\end{array}$ & & $\begin{array}{l}\text { freezing with extended appendages, decrease in } \\
\text { activity, immobilization for up to } 113 \text { min; animals } \\
\text { stopped activities such as walking or eating; } \\
\text { recovery within } 2-4 \text { hours; } 7-8 \% \text { decrease in heart } \\
\text { rate }\end{array}$ & $\begin{array}{l}\text { Bowles et al. } \\
1997 \mathrm{a}\end{array}$ \\
\hline $\begin{array}{l}\text { Desert tortoise } \\
\text { (Gopherus agassizii) }\end{array}$ & $\begin{array}{l}\text { recorded sound } \\
\text { from Air Force } \\
\text { aircraft, } 20 \\
\text { exposures over } 40 \\
\text { min }\end{array}$ & & $\begin{array}{l}114.2 \\
\text { CSEL }^{1}, \\
126.1 \\
\text { maximum } \\
\text { sound } \\
\text { pressure } \\
\text { level }\end{array}$ & no temporary acoustic threshold shift & $\begin{array}{l}\text { Bowles et al. } \\
1997 \mathrm{~b}\end{array}$ \\
\hline $\begin{array}{l}\text { Desert iguana } \\
\text { (Dipsosaurus dorsalis) }\end{array}$ & $\begin{array}{l}\text { simulated } \\
\text { motorcycle noise }\end{array}$ & $\begin{array}{l}115 \mathrm{dBA}, 1 \\
\text { hr duration }\end{array}$ & & $\begin{array}{l}\text { decreased cochlear responses (acoustical } \\
\text { sensitivity) greater than } 7 \text { days duration }\end{array}$ & Bondello 1976 \\
\hline $\begin{array}{l}\text { Mojave fringe-toed sand } \\
\text { lizard (Uma scoparia) }\end{array}$ & $\begin{array}{l}\text { recorded dune } \\
\text { buggy sounds }\end{array}$ & $\begin{array}{l}95 \text { dBA, } 8.5 \\
\text { min duration, } \\
\text { in cycles of } \\
30 \text { sec on, } 5 \\
\text { sec off }\end{array}$ & & $\begin{array}{l}\text { decreased amplitudes and increased latencies of } \\
\text { neural responses to standard auditory stimuli } \\
\text { (hearing loss), duration unknown }\end{array}$ & $\begin{array}{l}\text { Brattstrom and } \\
\text { Bondello } 1983\end{array}$ \\
\hline
\end{tabular}

${ }^{1} \mathrm{C}$-weighted sound exposure level; C-weighting includes audible sounds as well as low inaudible frequencies that lead to vibration of buildings; $\mathrm{C}$-weighting is a common metric for human community annoyance associated with blast noise 
Table 19. Aircraft distance and sound thresholds for effects on pinnipeds.

\begin{tabular}{|c|c|c|c|c|c|c|}
\hline Species & Stressor & LOAEL & NOAEL & Response & location & Reference \\
\hline $\begin{array}{l}\text { harbor seal (Phoca } \\
\text { vitulina) }\end{array}$ & $\begin{array}{l}\text { fixed wing and } \\
\text { rotary wing aircraft }\end{array}$ & $305 \mathrm{~m}$ altitude & & $\begin{array}{l}\text { vacate beaches--variable } \\
\text { response dependent on } \\
\text { weather, aircraft type, etc. }\end{array}$ & Alaska & Johnson 1977 \\
\hline $\begin{array}{l}\text { harbor seal (Phoca } \\
\text { vitulina) }\end{array}$ & $\begin{array}{l}\text { fixed wing and } \\
\text { rotary wing aircraft }\end{array}$ & $120 \mathrm{~m}$ altitude & & $\begin{array}{l}\text { vacate beaches, often for }>2 \\
h\end{array}$ & Alaska & Johnson 1977 \\
\hline $\begin{array}{l}\text { harbor seal (Phoca } \\
\text { vitulina) }\end{array}$ & helicopter & $305 \mathrm{~m}$ altitude & & $\begin{array}{l}7 \text { of } 25 \text { overflights produced } \\
\text { movement response ( } 1 \text { led } \\
\text { to rushing of } 50 \% \text { of } \\
\text { animals,; another to } 100 \% \\
\text { clearing of beach) }\end{array}$ & $\begin{array}{l}\text { San Miguel } \\
\text { Island, CA }\end{array}$ & $\begin{array}{l}\text { Bowles and Stewart } \\
1980\end{array}$ \\
\hline $\begin{array}{l}\text { harbor seal (Phoca } \\
\text { vitulina) }\end{array}$ & $\begin{array}{l}\text { prolonged flight of } \\
\text { military jet }\end{array}$ & $>244$ m altitude & & $\begin{array}{l}\text { rushing into water of all } \\
\text { animals (during } 24 \text { other } \\
\text { overflights, minimal } \\
\text { rushing) }\end{array}$ & $\begin{array}{l}\text { San Miguel } \\
\text { Island, CA }\end{array}$ & $\begin{array}{l}\text { Bowles and Stewart } \\
1980\end{array}$ \\
\hline $\begin{array}{l}\text { harbor seal (Phoca } \\
\text { vitulina) }\end{array}$ & aircraft & $150 \mathrm{~m}$ altitude & & $\begin{array}{l}\text { movement into water }(2 / 11 \\
\text { seals) and alert reactions }\end{array}$ & California & Osborn 1985 \\
\hline $\begin{array}{l}\text { harbor seal (Phoca } \\
\text { vitulina) }\end{array}$ & $\begin{array}{l}\text { broadband } \\
\text { construction noise, } \\
\text { rumble centered at } \\
100 \mathrm{~Hz} \text { and hiss } \\
\text { centered at } 5000 \\
\mathrm{~Hz}\end{array}$ & $\begin{array}{l}90 \text { to } 105 \mathrm{~dB} \text { sound } \\
\text { pressure level } \\
\text { (unweighted) }\end{array}$ & & $\begin{array}{l}\text { temporary acoustic } \\
\text { threshold shift of } 8 \mathrm{~dB} \text { at } \\
100 \mathrm{~Hz},<1 \text { week duration }\end{array}$ & & $\begin{array}{l}\text { Kastak and } \\
\text { Schusterman } 1996\end{array}$ \\
\hline $\begin{array}{l}\text { ringed seal (Phoca } \\
\text { hispida) and } \\
\text { bearded seal } \\
\text { (Erignathus } \\
\text { barbatus) } \\
\end{array}$ & helicopter & $\begin{array}{l}\text { lateral distance } \\
\text { about } 2 \mathrm{~km} \text {, altitude } \\
\text { of } 305 \mathrm{~m} \text { or less }\end{array}$ & $\begin{array}{l}\text { altitude of } 457 \\
\text { m or higher }\end{array}$ & $\begin{array}{l}\text { movement from haul-out } \\
\text { sites in subnivean lairs into } \\
\text { water }\end{array}$ & & Kelly et al. 1986 \\
\hline $\begin{array}{l}\text { spotted seal } \\
\text { (Phoca largha) }\end{array}$ & $\begin{array}{l}\text { Cessna } 206 \text { or } \\
\text { Aero Commander } \\
\text { Shrike or Cessna } \\
207\end{array}$ & $\begin{array}{l}914 \mathrm{~m} \text { altitude, } 500 \\
\mathrm{~m} \text { lateral distance } \\
\text { (calc. } 1042 \mathrm{~m} \text { slant } \\
\text { distance) }\end{array}$ & & $\begin{array}{l}\text { movement from haul out on } \\
\text { beaches to water, but } \\
\text { apparent return to beaches } \\
\text { after 2-3 hours }\end{array}$ & $\begin{array}{l}\text { Chukchi Sea, } \\
\text { Alaska }\end{array}$ & Frost et al. 1993 \\
\hline
\end{tabular}




\begin{tabular}{|c|c|c|c|c|c|c|}
\hline Species & Stressor & LOAEL & NOAEL & Response & location & Reference \\
\hline $\begin{array}{l}\text { California sea lion } \\
\text { (Zalophus } \\
\text { californiansus) }\end{array}$ & military jet & $305 \mathrm{~m}$ altitude & $\begin{array}{l}\text { altitude above } \\
305 \mathrm{~m}\end{array}$ & $\begin{array}{l}\text { limited movement (6/7) but } \\
\text { no major reaction }\end{array}$ & $\begin{array}{l}\text { San Miguel } \\
\text { Island, CA }\end{array}$ & $\begin{array}{l}\text { Bowles and Stewart } \\
1980\end{array}$ \\
\hline $\begin{array}{l}\text { California sea lion } \\
\text { (Zalophus } \\
\text { californiansus) }\end{array}$ & $\begin{array}{l}\text { helicopters, low } \\
\text { and landing }\end{array}$ & $305 \mathrm{~m}$ altitude & $\begin{array}{l}\text { altitude above } \\
305 \mathrm{~m}\end{array}$ & $\begin{array}{l}\text { some movement ( } 27 / 78) \text {, } \\
\text { occasional major rushes into } \\
\text { water, always raising of } \\
\text { heads }\end{array}$ & $\begin{array}{l}\text { San Miguel } \\
\text { Island, CA }\end{array}$ & $\begin{array}{l}\text { Bowles and Stewart } \\
1980\end{array}$ \\
\hline $\begin{array}{l}\text { walrus (Odobenus } \\
\text { rosmarus) }\end{array}$ & $\begin{array}{l}\text { veering of Bell } 206 \\
\text { jet ranger } \\
\text { helicopter, causing } \\
\text { abrupt change in } \\
\text { pitch }\end{array}$ & $\begin{array}{l}1300 \mathrm{~m} \text { lateral } \\
\text { distance, }<150 \mathrm{~m} \\
\text { altitude }\end{array}$ & $\begin{array}{l}1300 \mathrm{~m} \text { lateral } \\
\text { distance, }<150 \\
\mathrm{~m} \text { altitude, no } \\
\text { veering of } \\
\text { aircraft }\end{array}$ & $\begin{array}{l}55 \% \text { of animals rushing into } \\
\text { water from haul-out } \\
\text { locations }\end{array}$ & $\begin{array}{l}\text { Bathurst } \\
\text { Island, } \\
\text { Northwest } \\
\text { Territories, } \\
\text { Canada } \\
\end{array}$ & Salter 1979 \\
\hline $\begin{array}{l}\text { walrus (Odobenus } \\
\text { rosmarus) }\end{array}$ & $\begin{array}{l}\text { single Otter } \\
\text { helicopter }\end{array}$ & $\begin{array}{l}1000 \mathrm{~m} \text { altitude, } \\
\text { overhead }\end{array}$ & & $\begin{array}{l}41 \% \text { of animals rushing into } \\
\text { water from haul-out } \\
\text { locations }\end{array}$ & $\begin{array}{l}\text { Bathurst } \\
\text { Island, } \\
\text { Northwest } \\
\text { Territories, } \\
\text { Canada } \\
\end{array}$ & Salter 1979 \\
\hline $\begin{array}{l}\text { walrus (Odobenus } \\
\text { rosmarus) }\end{array}$ & IL-14 aircraft & $150 \mathrm{~m}$ altitude & & $\begin{array}{l}\text { stampede resulting in } \\
\text { crushing of calves and } \\
\text { abortion of } 2 \text { fetuses }\end{array}$ & & $\begin{array}{l}\text { Tomilin and } \\
\text { Kibal'chich } 1975 \text { in } \\
\text { Fay } 1981\end{array}$ \\
\hline $\begin{array}{l}\text { walrus (Odobenus } \\
\text { rosmarus) }\end{array}$ & unknown aircraft & $800 \mathrm{~m}$ altitude & & $\begin{array}{l}\text { death of } 102 \text { walruses, } \\
\text { probably by stampede }\end{array}$ & Wrangel Island & $\begin{array}{l}\text { Ovsyanikov et al. } \\
1994\end{array}$ \\
\hline $\begin{array}{l}\text { walrus (Odobenus } \\
\text { rosmarus) }\end{array}$ & $\begin{array}{l}\text { Twin Otter survey } \\
\text { aircraft }\end{array}$ & $305 \mathrm{~m}$ altitude & & $\begin{array}{l}\text { reaction of } 38 \% \text { of } 229 \\
\text { groups on pack ice (diving } \\
\text { splash or "escape" to water) }\end{array}$ & & $\begin{array}{l}\text { Brueggeman et al. } \\
1990\end{array}$ \\
\hline $\begin{array}{l}\text { walrus (Odobenus } \\
\text { rosmarus) }\end{array}$ & $\begin{array}{l}\text { helicopter flying } \\
\text { upwind }\end{array}$ & $\begin{array}{l}400-600 \mathrm{~m} \\
\text { horizontal distance }\end{array}$ & & $\begin{array}{l}\text { movement from open pack } \\
\text { ice to water }\end{array}$ & & Fay et al. 1986 \\
\hline $\begin{array}{l}\text { walrus (Odobenus } \\
\text { rosmarus) }\end{array}$ & $\begin{array}{l}\text { helicopter flying } \\
\text { downwind }\end{array}$ & $\begin{array}{l}1000-1800 \mathrm{~m} \\
\text { horizontal distance }\end{array}$ & & $\begin{array}{l}\text { movement from open pack } \\
\text { ice to water }\end{array}$ & & Fay et al. 1986 \\
\hline $\begin{array}{l}\text { walrus (Odobenus } \\
\text { rosmarus) }\end{array}$ & fixed wing aircraft & $100 \mathrm{~m}$ altitude & & $\begin{array}{l}2.2 \%(100 / 4500) \text { entered } \\
\text { the water, } 22 \%(1000 / 4500)\end{array}$ & & Fay et al. 1986 \\
\hline
\end{tabular}


70

\begin{tabular}{|l|l|l|l|l|l|l|}
\hline Species & Stressor & LOAEL & NOAEL & Response & location & Reference \\
\hline & & & & raised heads & & \\
\hline
\end{tabular}


Table 20. Aircraft distance thresholds for effects on cetaceans and sirenians.

\begin{tabular}{|c|c|c|c|c|c|c|}
\hline Species & Stressor & LOAEL & NOAEL & Response & location & Reference \\
\hline $\begin{array}{l}\text { beluga } \\
\text { (Delphinapterus } \\
\text { leucas) }\end{array}$ & unknown aircraft & $\begin{array}{l}200 \mathrm{~m} \\
\text { altitude }\end{array}$ & $\begin{array}{l}500 \mathrm{~m} \\
\text { altitude }\end{array}$ & $\begin{array}{l}\text { increase in duration of diving, } \\
\text { decrease in duration of surface } \\
\text { intervals, sometimes swimming } \\
\text { away }\end{array}$ & & $\begin{array}{l}\text { Bel'kovich } \\
(1960)\end{array}$ \\
\hline $\begin{array}{l}\text { beluga } \\
\text { (Delphinapterus } \\
\text { leucas) }\end{array}$ & Bell 206 & $\begin{array}{l}305 \mathrm{~m} \\
\text { altitude }\end{array}$ & & diving & & $\begin{array}{l}\text { Sergeant and } \\
\text { Hoek } 1988\end{array}$ \\
\hline $\begin{array}{l}\text { beluga } \\
\text { (Delphinapterus } \\
\text { leucas) }\end{array}$ & $\begin{array}{l}\text { high-wing, twin-engine Aero } \\
\text { Commander Shrike, } 220 \mathrm{~km} / \mathrm{h}\end{array}$ & & $\begin{array}{l}305 \mathrm{~m} \\
\text { altitude }\end{array}$ & no apparent behavioral response & $\begin{array}{l}\text { northeastern } \\
\text { Chuchki Sea }\end{array}$ & $\begin{array}{l}\text { Frost et al. } \\
1993\end{array}$ \\
\hline $\begin{array}{l}\text { Baird's (Berardius } \\
\text { bairdii)and Cuvier's } \\
\text { beaked whales }\end{array}$ & $\begin{array}{l}\text { medium-sized Pembroke } \\
\text { aircraft }\end{array}$ & $\begin{array}{l}305 \mathrm{~m} \\
\text { altitude }\end{array}$ & & $\begin{array}{l}\text { diving and remaining submerged } \\
\text { for long duration }\end{array}$ & & $\begin{array}{l}\text { Dohl et al. } \\
1983\end{array}$ \\
\hline $\begin{array}{l}\text { multiple species of } \\
\text { dolphin }\end{array}$ & Bell 204 & & $\begin{array}{l}370 \mathrm{~m} \\
\text { altitude }\end{array}$ & no behavioral reaction & & Hewitt 1985 \\
\hline $\begin{array}{l}\text { dolphin species } \\
\text { (Stenella attenuata, } \\
\text { S. longirostris, } S \text {. } \\
\text { coeruleoalba) }\end{array}$ & Bell 204 & & $\begin{array}{l}370 \mathrm{~m} \\
\text { altitude }\end{array}$ & no behavioral reaction & & $\begin{array}{l}\text { Au and } \\
\text { Perryman } \\
1982\end{array}$ \\
\hline $\begin{array}{l}\text { bowhead whale } \\
\text { (Balaena } \\
\text { mysticetus) }\end{array}$ & $\begin{array}{l}\text { Britten-Norman Islander } \\
\text { twin-engined, high-wing } \\
\text { aircraft circling for } 0.8 \text { to } 1.9 \\
\mathrm{~h}\end{array}$ & $\begin{array}{l}457 \mathrm{~m} \\
\text { altitude }\end{array}$ & $\begin{array}{l}610 \mathrm{~m} \\
\text { altitude }\end{array}$ & $\begin{array}{l}\text { hasty dive by } 6 \text { of } 27 \text { whales } \\
(22 \%) \text {, movement away from } \\
\text { aircraft by unknown percentage }\end{array}$ & & $\begin{array}{l}\text { Richardson et } \\
\text { al. 1985a }\end{array}$ \\
\hline $\begin{array}{l}\text { feeding bowhead } \\
\text { whales (Balaena } \\
\text { mysticetus) }\end{array}$ & $\begin{array}{l}\text { Britten-Norman Islander } \\
\text { twin-engined, high-wing } \\
\text { aircraft circling for } 30 \mathrm{~min} \text {, } \\
\text { one event }\end{array}$ & & $\begin{array}{l}305 \mathrm{~m} \\
\text { altitude }\end{array}$ & no disturbance response & & $\begin{array}{l}\text { Richardson et } \\
\text { al. 1985a }\end{array}$ \\
\hline $\begin{array}{l}\text { bowhead whale } \\
\text { (Balaena } \\
\text { mysticetus) }\end{array}$ & turbine helicopter, 5 passes & & $153 \mathrm{~m}$ & no detectable behavioral response & & $\begin{array}{l}\text { Richardson et } \\
\text { al. } 1985 \mathrm{~b}\end{array}$ \\
\hline $\begin{array}{l}\text { bowhead whale } \\
\text { (Balaena }\end{array}$ & $\begin{array}{l}\text { helicopter engaged in aerial } \\
\text { photogrammetry }\end{array}$ & $150 \mathrm{~m}$ & & $\begin{array}{l}\text { frequent abrupt turns and hasty } \\
\text { dives, but return of animals to }\end{array}$ & & $\begin{array}{l}\text { Koski et al } \\
1988\end{array}$ \\
\hline
\end{tabular}




\begin{tabular}{|c|c|c|c|c|c|c|}
\hline Species & Stressor & LOAEL & NOAEL & Response & location & Reference \\
\hline mysticetus) & & & & same area next day & & \\
\hline $\begin{array}{l}\text { bowhead whale } \\
\text { (Balaena } \\
\text { mysticetus) }\end{array}$ & P-3 patrol aircraft & $\begin{array}{l}250 \mathrm{~m} \\
\text { altitude }\end{array}$ & & dive & & $\begin{array}{l}\text { Ljungblad } \\
1986\end{array}$ \\
\hline $\begin{array}{l}\text { gray whale } \\
\text { (Eschrichtius } \\
\text { robustus) }\end{array}$ & UH-1N (Bell 212) & $\begin{array}{l}305-365 \mathrm{~m} \\
\text { altitude }\end{array}$ & $\begin{array}{l}425 \mathrm{~m} \\
\text { altitude }\end{array}$ & abrupt turn or dive & & $\begin{array}{l}\text { SRA } 1988 \text { as } \\
\text { cited in } \\
\text { Richardson et } \\
\text { al. } 1991\end{array}$ \\
\hline $\begin{array}{l}\text { gray whale } \\
\text { (Eschrichtius } \\
\text { robustus) }\end{array}$ & $\begin{array}{l}\text { small turboprop survey } \\
\text { aircraft }\end{array}$ & $\begin{array}{l}335 \mathrm{~m} \\
\text { altitude }\end{array}$ & & $\begin{array}{l}\text { adult frequently moved over calf, } \\
\text { or calf swam under adult }\end{array}$ & & $\begin{array}{l}\text { Clarke et al. } \\
1989\end{array}$ \\
\hline $\begin{array}{l}\text { gray whale } \\
\text { (Eschrichtius } \\
\text { robustus) } \\
\end{array}$ & $\begin{array}{l}\text { recorded underwater sounds } \\
\text { from Bell } 212 \text { helicopter, } 3 \\
\text { simulated passes per min }\end{array}$ & $\begin{array}{l}115 \mathrm{~dB} \text { re } \\
1 \mu \mathrm{Pa}\end{array}$ & & $10 \%$ minor avoidance reactions & & $\begin{array}{l}\text { Malme et al. } \\
1983\end{array}$ \\
\hline $\begin{array}{l}\text { minke whale } \\
\text { (Balaenoptera } \\
\text { acutorostrata) }\end{array}$ & HH-52A turbine helicopter & $\begin{array}{l}229 \mathrm{~m} \\
\text { altitude }\end{array}$ & & $\begin{array}{l}\text { change in course, roll to side or } \\
\text { sounding or occasional strong } \\
\text { fright reaction }\end{array}$ & $\begin{array}{l}\text { Ross Sea, } \\
\text { Antarctica }\end{array}$ & $\begin{array}{l}\text { Leatherwood } \\
\text { et al. } 1982\end{array}$ \\
\hline $\begin{array}{l}\text { humpback whale } \\
\text { (Megaptera } \\
\text { novaeangliae) }\end{array}$ & $\begin{array}{l}\text { low frequency sound: } \mathrm{M} \\
\text { sequence centered at } 75 \mathrm{~Hz} \\
\text { with } 30-\mathrm{Hz} \text { playback }\end{array}$ & $\begin{array}{l}120 \mathrm{~dB} \text { re } \\
1 \mu \mathrm{Pa} \\
\text { estimated } \\
\text { received } \\
\text { level, average } \\
\text { for upper } 10- \\
80 \mathrm{~m} \text { of } \\
\text { water column }\end{array}$ & & $\begin{array}{l}3 / 11 \text { movements of whales ( } 2 \\
\text { toward sound source, } 2 \text { away) }\end{array}$ & Hawaii & $\begin{array}{l}\text { Frankel and } \\
\text { Clark } 1998\end{array}$ \\
\hline $\begin{array}{l}\text { humpback whale } \\
\text { (Megaptera } \\
\text { novaeangliae) }\end{array}$ & $\begin{array}{l}\text { Acoustic Thermometry of } \\
\text { Ocean Climate signal ( } 60 \text { to } \\
90 \mathrm{~Hz} \text { band, source level at } \\
195 \mathrm{~dB} \text { re } 1 \mu \mathrm{Pa} \text { at } 1 \mathrm{~m})\end{array}$ & & $\begin{array}{l}130 \mathrm{~dB} \text { re } \\
1 \mu \mathrm{Pa}\end{array}$ & $\begin{array}{l}\text { no change in number and density, } \\
\text { number of singers, or behavior }\end{array}$ & & Clark 1998 \\
\hline $\begin{array}{l}\text { manatee (Trichechus } \\
\text { manatus) }\end{array}$ & $\begin{array}{l}\text { Bell 47G helicopter, up to } 20 \\
\mathrm{~km} / \mathrm{h}, 120 \text { min survey }\end{array}$ & $\begin{array}{l}<100 \mathrm{~m} \\
\text { altitude }\end{array}$ & $\begin{array}{l}\text { about } 100 \\
\text { m altitude }\end{array}$ & $\begin{array}{l}\text { animals resting on shallow ledges } \\
\text { moved to deep water }\end{array}$ & $\begin{array}{l}\text { Crystal } \\
\text { River, FL } \\
\text { and Indian } \\
\text { River, FL }\end{array}$ & Rathbun 1988 \\
\hline
\end{tabular}




\subsection{RELATIONSHIP TO ENDPOINTS (6.3)}

Models are needed to extrapolate from measured or estimated effects to assessment endpoints. For most wildlife assessment endpoints, the properties of concern are abundance and production. Few models exist to relate behavioral reactions (such as startled flight) or a temporary change in acoustic threshold or heart rate to the endpoint properties. Similarly, it is difficult to estimate the likelihood of home range shifts if all that is known is the average distance that a startled caribou moved. Clearly, there is a large research gap that should be filled in one of two ways: 1) more direct studies of the effects of military overflights on abundance and production are needed or 2) more studies relating changes on behavior to changes in abundance and production are needed.

In the absence of these models, qualitative statements must be incorporated into the ecological risk assessment. These may include a series of contingencies. For example, if startling of seals leads to rushing from land, which leads to mother-pup separation, seal mortality may result (Bowles and Stewart 1980). Similarly, if overflights result in a reduction in hearing acuity of a young caribou calf, that may result in an inability to hear a potential predator, which may lead to decreases in abundance or reproduction (Fig. 5). If quantitative models of these contingent processes are not available, the assessor can be fairly confident that effects further down the contingency hierarchy are less likely to occur. Thus, a behavioral change in $20 \%$ of a local population or a behavioral change that occurs during $20 \%$ if overflights is expected to result in less (perhaps very much less) than a $20 \%$ change in abundance or production.

If the extrapolation is from a tested species to an unstudied species that is an assessment endpoint entity, the problem is that acoustic thresholds and effects thresholds vary among species. The differences in effects thresholds are poorly understood, and no physiologically-based models exist for such extrapolation. Species sensitivity distributions (Fig. 2, 3,4) may be used to estimate the variability in effects thresholds among a group of species that is likely to react to sound or to sound and the aircraft image (slant distance) through similar behavior, though effects thresholds for sound pressure are not known for many groups of species. In a cumulative sensitivity distribution, the $\mathrm{x}$-axis represents effects thresholds, and the $\mathrm{y}$-axis is the percentile or fraction of organisms that are affected at each level (e.g., sound intensity). In order for the distribution to represent the risks to a species, effects levels of related species are plotted, and the distribution represents the probability that the species of concern is affected at a given sound level or slant distance from a random aircraft. Thus, there is a 25\% likelihood that an overflight within $1000 \mathrm{~m}$ of a particular group of pinnipeds will result in a behavioral effect (e.g., most hauled out seals diving into water). Based on the distribution of slant distance thresholds for pinnipeds (Fig. 4), the risk assessor may suspect that ringed seals and bearded seals are less sensitive to overflights than most other pinnipeds. However, given the single data point for these species, the conservative approach would be to assume that the thresholds for these species are random elements of the entire distribution of thresholds for pinnipeds.

Hearing damage is not necessarily related to the acoustic threshold for the particular species. Therefore, it is not advisable to extrapolate effects thresholds by adjusting the weighting of sound levels. Hearing damage in vertebrates is commonly induced when exposures are higher than the highest sound intensities that the animal normally experiences, such as thunder (A E. Bowles, pers. comm. 3/98). Much research is required before sound level thresholds for hearing damage can be extrapolated from a tested species to an untested one.

For any necessary extrapolations among species for which no models are available, the uncertainties must be stated in the risk characterization, and risk assessors and site managers may decide that certain safety factors should be used in the assessment. Based on the moderate number of slant distance thresholds 
and few sound pressure level thresholds available for the different classes of endpoints, it is recommended that a safety factor of 10 be used if slant distance is the measure of exposure and that 10 decibels be subtracted as a safety factor if sound pressure is the measure of exposure.

Mortality due to bird strikes may be extrapolated to determine if there is a population-level effect. Simple demographic models may be used.

No comparative data are available for the impacts of winds from aircraft takeoffs and landings on different plant communities; hence, good extrapolation models are not available.

\subsection{EFFECTS PROFILES: RECOMMENDATIONS FOR EFFECTS ANALYSIS (6.4)}

Exposure-response models and related information for each endpoint and stressor are presented below. The risk assessor should consider the thresholds in Sect. 4.1.3; other empirical or mechanistic effects models described below; the relevance of effects estimates to abundance and production endpoints (or behavioral if the species is a marine mammal or endangered); the relevance of effects models to the species, aircraft, and environment of concern; the relative importance of visual and noise stressors; the importance of seasonal activities and energetics to response; and the likelihood and conditions of habituation. In general, there is a moderate amount of information on behavioral effects associated with overflights, but little on abundance and reproduction.

Exposure-response models are generally lacking in the following areas:

- $\quad$ long-term measurements of populations exposed to aircraft overflights,

- models that relate behavioral changes to abundance or reproduction,

- $\quad$ models that relate effects on one population to effects on another,

- models which can distinguish among effects levels (where it is possible to name a threshold at which a $20 \%$ or $50 \%$ level of effects occurs),

- $\quad$ models precise enough to distinguish among effects associated with different aircraft,

- models that relate frequency or type of overflights occurring at night to effects,

- $\quad$ models that relate frequency of overflights to effects, and

- $\quad$ models of the effects of takeoffs and landings.

\subsubsection{Raptors}

Effects on a large number of raptor species have been studied, and many of those studies have involved military aircraft. Most raptors make their nests on cliffs and perch on the tops of trees and can therefore see the aircraft approach. In one study, nests were selected where red-tailed hawks could watch helicopters approach from $500 \mathrm{~m}$ (Andersen et al. 1989). Because exposure includes both sound and the visual image of the aircraft, slant distance is probably a better measure of exposure than sound. A possible exception is the threshold for effects on the Mexican spotted owl. Because the helicopter was not very visible to the owl in the study by Delaney et al. (1999), the slant distance could be converted to a sound exposure without losing much precision. Based on a study with osprey, the appropriate sound measure to use would be the maximum sound level (Trimper et al. 1998). No correlations have been established between noise onset rate and duration parameters and effects on osprey. 
Based on the threshold models, there is no apparent difference in raptor sensitivity to rotary-wing or fixed-wing aircraft. No models are available that relate effects to the frequency of overflights. A single study by D. Roby (Table 13) found reduced peregrine falcon nest productivity with increased frequency of overflights by military jets. However, the pairs that were less productive were less productive prior to the overflights (Roby, pers. comm. 3/99).

Direct measures of the reproductive success of birds could include: numbers of occupied nests, numbers of active nests (at least one egg laid), numbers of successful nests (at least one young fledged), clutch size, hatching success, or fledging success (Awbrey and Bowles 1989). Since these effects are rarely measured, the assessor must either 1) accept the conservative estimates of population-level effects that behavioral thresholds provide or 2) rely on models that relate startled flights and other non-reproductive behavior to reproductive endpoints. One such model relates numbers of young gyrfalcons per successful nest to frequency of flush response (Platt 1977). Some potential mechanisms of population-level effects may be discounted. For example, Awbrey and Bowles (1989) speculate that the probability that flight from a nest will lead to death of offspring due to overheating or chilling is negligible. Similarly, premature fledging in response to low-altitude aircraft overflights has never been observed (Awbrey and Bowles 1989).

Two models are available that directly relate to production of raptors, the NOAEL for nest attendance of osprey (Trimper et al. 1998) and the LOAEL for prey delivery rate of Mexican spotted owl. An additional study found that 34 of 38 raptor nest sites flown over by military jets fledged young that year and that 21 of 22 nests studied one year were reoccupied the following year (Ellis et al. 1991). This would suggest that reproduction of raptors is not very sensitive to overflights by military aircraft, but the NOAEL or LOAEL (slant distance or sound level) was not measured.

Most available models that are presented above are for flushing from the nest. Flushing may include circling and soaring, evading the aircraft, or approaching the aircraft to attack (Watson 1993). But even if parent birds are away from the nest for brief periods, this can lead to missed feedings; predation on eggs or young; premature fledging; or overheating, chilling, or desiccation of eggs or young (Richardson and Miller 1997, Trimper et al. 1998). For example, the death of a bald eagle nestling in Arizona has been attributed to frequent helicopter flights less than $30 \mathrm{~m}$ from nest; adults were kept away for long periods of time, and prey deliveries were reduced (Grubb and Bowerman 1997).

Awbrey and Bowles (1989) developed a "straw man" model to relate frequency of overflights to reproductive success of raptors, based on a meta-analysis of existing studies. The model first calculates a probability that a raptor will fly off the nest, based on slant distance. Unhabituated raptors always respond if the approach is at $50 \mathrm{~m}$ or closer, and probabilities of flushing decrease with distance and during certain stages of the breeding season (incubation and brooding, see evidence for diminished effects at these times below). At distances greater than $1500 \mathrm{~m}$ and less than $75 \mathrm{dBA}$ sound level, no reproductive effects are expected to occur. A chief assumption of the model is that there is a relationship between numbers of flushes and reproductive effects. The model incorporates an algorithm for habituation.

No studies have been performed to determine whether aircraft overflights are responsible for any decreases in prey density, which could lead to population-level effects on raptors (Awbrey and Bowles 1989).

Habituation of raptors has been observed in both owls (Delaney et al. 1999) and red-tailed hawks (Andersen et al. 1989). Habituation of raptors to repeated disturbance is believed to be a generic response; 
sensitization (increased degree of effect with repeated exposure) has never been observed in response to overflights (Awbrey and Bowles 1989). Habituation of raptors to disturbance typically takes a few days if exposures are regular, and a month if exposures are infrequent (Awbrey and Bowles 1989). Thus, the major impacts of overflights on raptor populations may only occur in the first breeding season that coincides with a new training activity. If no impacts to unhabituated birds are observed in a period that includes a breeding season, then it may be assumed that no population-level impacts will occur. Awbrey and Bowles (1989) attribute the variance in sound and slant distance thresholds for raptors to differences in habituation rather than differences in species sensitivity.

The location of the birds can influence the behavioral reaction. Bald eagles were disturbed less when there were young in the nest or if they were perched less than $60 \mathrm{~m}$ from nest than if they were present in the nest with no young (Watson 1993). Similarly, environmental factors may influence the magnitude of effects. For example, higher wind velocities and precipitation apparently reduced the disturbance response of bald eagles to overflights (Watson 1993).

Effects are often dependent on the age of the birds. Young peregrine falcons were more sensitive to overflights than adults (Roby, personal communication 3/99). Young raptors less than 2 weeks old did not react to overflights (Ellis et al. 1991). Large young often cowered or moved deep into the eyrie as aircraft passed (Ellis et al. 1991). Incubating or brooding adult raptors never left the nest (Ellis et al. 1991, Craig and Craig 1984, Awbrey and Bowles 1989).

\subsubsection{Waterfowl}

Effects on a large number of shorebirds and other waterfowl have been studied, but few observations have involved military jets or large military helicopters. An exception is the departure of a flock of 500 cormorants after a 30-minute series of military jet overflights (no altitude recorded, Bowles and Stewart 1980). Waterfowl are highly exposed to overflights, with nests and activities in the open. Because they can typically see the aircraft approach, slant distance is probably a better measure of exposure than sound. Indeed, in one study, the lateral distance between small, fixed-wing aircraft and flocks of brant and Canada geese was a more important parameter than sound or aircraft type in predicting response of brant and Canada geese to overflights (Ward et al. 1999). (Interestingly, though, responses of the birds were greatest when the altitude of the aircraft was between 305 and $760 \mathrm{~m}$ rather than below $305 \mathrm{~m}$.) However, brant and Canada geese (Ward et al. 1999) and pink-footed geese and barnacle geese (Mosbech and Glahder 1991) were sometimes observed to fly away before the aircraft was visible, so the visual stressor was not required for the response.

If slant distance is used as the measure of exposure, it should be noted that military aircraft are typically larger and louder than those aircraft tested. Therefore, behavioral effects associated with military aircraft overflights would be expected to be somewhat larger in magnitude than those associated with survey or other light aircraft.

Based on the threshold models, there is no apparent difference in sensitivity to rotary-wing or fixed-wing aircraft. Only one model is available that relates response to the frequency of overflights. This is the energy balance of fall-staging snow geese, related to number of disturbances per hour (Belanger and Beddard 1990). 
Behavioral thresholds are the primary models available for effects of overflights on waterfowl. A probabilistic model for the flight of Pacific brant following overflights by small fixed-wing and rotary-wing aircraft is presented in Ward et al. (1999, see Table 13). The model is very useful for brant at one location in Alaska, but somewhat less useful if: 1) other species of waterfowl are of interest, 2) other locations are of interest, and 3) larger aircraft are the stressors. Although the simulation model for Pacific black brant in Miller et al. (1994) is quite useful for that species near Teshekpuk Lake, Alaska, the model relies on 10 years of demographic data for that species and location. To be useful for estimating weight loss of waterfowl in a risk assessment for overflights, the model would have to be modified for other species in other locations.

Methods must be developed to relate behavioral effects to effects on abundance and production. Energy loss is more directly related to production than behavior is. For example, molting is energetically costly, and it is hypothesized that stress from overflights may prevent birds from concurrently molting and obtaining food sufficient for migration to staging areas (Miller et al. 1994). Feeding frequency and duration are surrogate measures of production (growth). Snow geese in Quebec often stopped feeding following overflights at an unquantified slant distance (Belanger and Bedard 1989). Loss of feeding time was always at least 15 min per disturbance. Thus, weight loss is predictable if typical feeding times and frequencies of overflights are known.

Additional mechanisms of population-level effects on waterfowl are possible. Distraction resulting from aircraft overflights may result in increased risk of predation on these birds. For example, one observer saw an arctic fox catch a white-fronted goose that was running from an approaching helicopter (Derksen 1992). If nest attendance is reduced following overflights, populations could be impacted. However, one NOAEL suggests that attendance of incubating and brooding mixed colonies of fulmars and other species is not impacted by low-altitude overflights of small survey aircraft (Dunnet 1977, Table 15). Also, if geese leave the area, the local population could be reduced. For example, when the mean hourly disturbance rate of snow geese was greater than 2 per hour, the numbers of geese were lower the next day (Belanger and Bedard 1989).

Evidence regarding the habituation of waterfowl to aircraft overflights is mixed. Fewer black ducks fled from military aircraft after exposure for 17 days than initially (Conomy et al. 1998). Similarly, the fraction of ducks reacting to simulated aircraft noise was reduced after 4 days of exposure (Conomy et al. 1998). There is weak evidence for reduction in mean flight response of brant to rotary-wing aircraft over 36 day exposure period (Miller et al. 1994). In contrast, Derksen et al. (1992) found that there was no daily or seasonal habituation of molting black brant to overflights by helicopters. Additional unpublished studies of brant and wintering pink-footed geese which did not habituate to aircraft overflights and other disturbances are cited in Derksen et al. (1992). Similarly, dark-bellied brent geese displayed little or no habituation to overflights (Owens 1977). In contrast to the black ducks above, wood ducks in the same study did not habituate to overflights by military aircraft or to recordings of jet noise (Conomy et al. 1998).

Other factors may determine the magnitude of the response to overflights. Flock size of brant was an important factor determining flock response to overflights of molting brant (Derksen et al. 1992). Similarly, the response of snow geese was greater for larger flocks (Belanger and Bedard 1989). The seasonal timing of overflights may play a role in the response. Pink-footed geese and barnacle geese are particularly sensitive to helicopter sound when they are settling for molting but still able to fly (Mosbech and Glahder 1991). Also, responses of snow geese, including the time before feeding resumed, were greater in the fall than in the spring (Belanger and Bedard 1989). 


\subsubsection{Birds Susceptible to Bird Strikes}

As stated above, the model of exposure (probability of collision) is a model of effects, because contact is equivalent to mortality. The best prediction tool is the Bird Flight Forecast and Information System developed by the Center for Conservation Research \& Technology, housed at the University of Maryland, Baltimore County. As stated in Sect. 3.4.3, this avian flight model, based on weather, is being parameterized for several bird species. The model should be used in combination with a collision probability model, described in simple terms in Sect. 3.4.3. The extrapolation of individual-level to population-level effects is addressed briefly in Sect. 4.3. Because of mitigative measures at air bases, it is unlikely that bird strikes would result in population-level impacts unless the population of concern is threatened or endangered.

\subsubsection{Ungulates}

Effects of overflights on a several ungulates have been studied, with an emphasis on caribou. Most ungulates are highly exposed to overflights, engaging in feeding and other activities in the open. Because these animals can typically see the aircraft approach, slant distance is probably a better measure of exposure than sound. In contrast, ungulates such as deer in the eastern or northwestern forests may be surrounded by tree cover; aircraft may not be visible to them. For these populations, sound pressure level is an equally appropriate measure of exposure, and slant distances may be converted to a sound exposure without losing the impact of the visual stressor. Also, a few valuable exposure-response models from Maier et al. 1998, in which sound pressure was measured by monitors on a radio collar, use sound as the measure of exposure.

Most models relate behavior of ungulates to slant distance or altitude. A few use frequency of overflight as a measure of exposure (Table 13). These include the survival of woodland caribou calves (Harrington and Veitch 1992) and the number and duration of resting bouts of barren-ground caribou (Maier et al. 1998). Maier et al. (1998) noted that ungulates tend to respond more strongly to overflights by helicopters than those by light or jet aircraft, but that is not clear based on the thresholds in Table 16 .

Few exposure-response models are direct measures of abundance or production of ungulates. At between a 250- and 450-m distance from helicopters, desert bighorn sheep displayed reduced foraging efficiency (Stockwell et al. 1991). The survival of woodland caribou calves was negatively correlated with the number of jet overflights reported less than $1 \mathrm{~km}$ from the animal's location per day (Harrington and Veitch 1992). Caribou nursed less frequently when exposed to overflights (Gunn et al. 1985). Mountain sheep changed their use of vegetation types following exposure to helicopter overflights (Bleigh et al. 1994), suggesting potential impacts on growth.

Most behavioral effects of overflights relate to animal movement, which may be related to abundance and production. Energy loss is an important predictor of production. Energetic costs of movement for ungulates are variable, with those for caribou lower than for other ungulates (Maier et al. 1998). If movement associated with overflights is combined with other high-energy activities (e.g. activity during the insect season, Maier et al. 1998), growth may be impaired. Movements to new habitats alter the abundance of the local population, and well as potentially lowering foraging success. For example, small changes in habitat quality can have large effects on caribou productivity (White 1983). Movement can alter the probability of encountering predators and the likelihood of separation of calves from mothers. 
Habituation of bighorn sheep and mule deer has been observed (Weisenberger et al. 1996). Similarly, barren-ground caribou of the Delta herd in interior Alaska are habituated to aircraft overflights (Valkenburg and Davis 1985).

The response of ungulates to overflights is dependent on the activity that the animals are engaged in at the time (Table 13). Barren-ground caribou at river crossings were most reactive to overflights, followed by traveling and feeding animals, and followed by resting animals (Calef et al. 1976). Woodland caribou ran further and for longer periods of time if they were initially walking, compared to animals that were resting, standing, or feeding (Harrington and Veitch 1991). Similarly, responses of muskoxen were dependent on the previous activity of the animals (Miller and Gunn 1979).

Season is also an important determinant of effects. Behavioral responses of female barren-ground caribou to military jets were strongest during postcalving, intermediate during the insect season, and lowest in the late winter (Maier et al. 1998). Mountain sheep move greater distances following helicopter disturbances in the spring than in other seasons (Bleich et al. 1994). During spring and fall migration periods, barren-ground caribou responses are greater than during calving (Calef et al. 1976). Vegetation type did not affect response of barren-ground caribou (Calef et al. 1976) but did determine distances that mountain sheep moved following overflights (Bleich et al. 1994).

\subsubsection{Small Mammals}

Most of the effects models for small mammals relate to sound rather than to slant distance. All are thresholds. It is not clear whether or not all small mammals should be grouped together, because acoustic thresholds may be largely different. If desert rodents are the subject of the assessment, the 95dBA threshold is not a conservative estimate of a LOAEL (see value for kangaroo rat, Table 17); the actual LOAEL for particular species could be lower. Hearing thresholds of some rodent species are likely to be impacted by low-altitude military overflights.

In the desert kangaroo rat, hearing thresholds were raised by 4 to 9 decibels by recordings of dune buggy noise at $95 \mathrm{dBA}$ (Brattstrom and Bondello 1983). Thus, the power intensity of the sound stimulus had to be increased by a factor of 2 to 8 to elicit responses equivalent to control animals (Brattstrom and Bondello 1983). Hearing is important for predator avoidance. If expressed as a distance at which a predator can be heard, the threshold distance dropped from greater than $40 \mathrm{~cm}$ to less than $2 \mathrm{~cm}$; the striking range of the sidewinder Crotalus is probably between 16 and $24 \mathrm{~cm}$. Similarly, the middle ear cavities of Merriam's kangaroo rats are greatly enlarged, with a large tympanic membrane that amplifies sound about 97 times (Brattstrom and Bondello 1983). These rats would be expected to be similarly affected. Given the duration of the acoustic threshold shift, it is likely that sound of 95dBA, of a similar frequency spectrum as dune buggy sound (which military overflights are), would reduce survivorship of these animals. It is also notable that the desert kangaroo rat lives in a habitat sufficiently specialized that animals would not likely move away from the stressor.

One study suggests that the abundance and diversity of desert rodents may not be affected by aircraft sound greater than 100dB, A-weighted SEL (Bowles et al. 1993). These exposures from the training racetracks of the Barry M. Goldwater Range in Arizona are among the highest exposures of any small mammals at military bases in the U. S. The results suggest that effects on hearing may not lead to population-level effects. 
Experimental data concerning non-desert rodents are insufficient to provide a very accurate estimate of effects. The increase in adrenal gland mass (Chesser et al. 1975) is not easily translated to effects on abundance or production. Similarly, an hour of Parisian subway noise (Busnel and Molin 1978) may not produce similar effects to aircraft overflights. Nonetheless, these effects models are better than no information.

\subsubsection{Reptiles}

Sound level threshold models are available for three reptilian species: the desert iguana, the Mojave fringe-toed sand lizard, and the desert tortoise. Sound pressure level rather than distance to overflight is the relevant measure of exposure. Only the studies of desert tortoise involved aircraft; the others related acoustical sensitivity to motorcycle sound output or dune buggy noise. It is not clear whether or not the impacts on hearing would be similar for other reptiles.

Although it was hypothesized that overflights might lead tortoises to energy-consuming behavior (Eckert et al. 1997) or to urinate, which would be harmful to a dehydrated tortoise (Bowles et al. 1997a), instead the animals tended to reduce their activities. This behavior could reduce growth of the organisms if feeding is suspended. Unpublished data also suggest that desert tortoises may experience temporary threshold shifts at levels of sound that are associated with military aircraft overflights. These data have not yet been approved for release (A. E. Bowles, pers. comm. 3/98).

The major energies of dune buggy sounds coincide with the frequencies of maximum acoustical sensitivity for Uma scoparia at 1.0 to $1.6 \mathrm{kHz}$. Hearing is important for prey acquisition and predator avoidance; the rustling of dry leaves by insects, insect sounds, snakes crawling on gravel, rattlesnakes striking, swooping owls all have strong frequency components between 1 and $4 \mathrm{kHz}$ (Brattstrom and Bondello 1983).

Little information suggests that desert tortoises habituate to the sound from aircraft overflights (Bowles et al. 1997a).

\subsubsection{Amphibians}

A single effects threshold is available for amphibians. The sound pressure level of $95 \mathrm{dBA}$ is probably specific to burrowing amphibians in arid regions. Premature emergence of a large fraction of an amphibian population is likely to lead to population-level impacts. Recently emerged toads are dehydrated and have depleted fat reserves and require food and water (Brattstrom and Bondello 1983). If premature emergence is in cold weather, egg hatching and larval development may be affected. Substantial evidence exists that Couch's spadefoot toad emerges in the presence of loud sounds. These include: thunder, rain, and hand drills (Brattstrom and Bondello 1983).

Risk assessors should consider the life history of the particular amphibian species to estimate potential risks from aircraft sound.

\subsubsection{Pinnipeds}


All but one of the effects models for pinnipeds are threshold models based on altitude or slant distance of overflights. Slant distance is a reasonable measure of exposure, given that pinnipeds are highly exposed to the visual stressor of the overflight. Indeed, it has been observed that sea lions react only when a visual stimulus is present; a helicopter must be seen above a cliff to cause a behavioral reaction (Bowles and Stewart 1980). Few overflights are of military aircraft, and most are of survey aircraft. Several species are represented.

Rushing into water is the major behavioral response, and for pinnipeds this does not constitute a disruption of feeding. A change in behavior is an endpoint property under the Marine Mammal Protection Act ${ }^{(1)}$, though the Act probably does not protect the animals from changes in alert responses, such as raising ears. One secondary source (Ovsyanikov et al. 1994) and one tertiary source (Tomilin and Kibal'chich 1975) have recorded instances of stampedes associated with overflights that affected abundance of walruses. Stampedes may result in pup mortality of increased rates of pup abandonment. Startle reactions have previously been observed to be precipitated by movements of birds (Bowles and Stewart 1980).

Although some pinnipeds may habituate to overflights, others, such as harbor seals, may exhibit increased responses with repeated exposure (Richardson et al. 1995). Data are too sparse for solid conclusions regarding habituation.

\subsubsection{Cetaceans and Sirenians}

Most of the effects models for cetaceans are threshold models based on altitude of overflights. Altitude is a reasonable measure of exposure if the aircraft flies overhead, given that cetaceans are most exposed when they surface. Monitoring exposure to sound would be costly and would probably not be feasible for a risk assessment. None of the overflights in available exposure-response models are of military aircraft, and most are of survey aircraft taking opportunistic measurements. Several species are represented, with a single threshold value available for sirenians (manatees). The effects typically consist of diving, and as with pinnipeds, changes in behavior constitute an endpoint for these animals.

Because the National Marine Fisheries Service has proposed the 120 decibel rule for exposure of marine mammals to sound, the assessor should consider this threshold in the effects assessment. This threshold is close to those observed in Malme et al. (1983), $120 \mathrm{~dB}$, and in Clark (1998), $115 \mathrm{~dB}$.

It is notable that for cetaceans, effects levels associated with responses are unquantified. Because it is difficult to quantify the number of whales in a location by aircraft, the fraction that change behavior is also difficult to quantify.

The activity of the cetaceans prior to the overflight contributes to the magnitude of response (Table 13). Bowhead whales engaged in mating, feeding, or socializing may be less sensitive to overflights than whales not engaged in these activities (Ljungblad 1981, Richardson et al. 1991). White whales were less affected by helicopters than swimming animals (Fraker and Fraker 1979). During spring migration, mating bowheads were less sensitive to survey aircraft than bowheads observed later in spring (Ljungblad 1981).

\subsubsection{Surface Soil}


Soil loss at a takeoff or landing site may be measured or modeled. Measurement is preferred, but a mechanistic model is presented in Sect. 4.1.2. Model accuracy is limited by the input parameters; default values are from agricultural sites. A source of data for soil parameters is the State Soil Geographic database (STATSGO), produced by the Natural Resources Conservation Service of USDA.

\subsubsection{Plant Community}

Impacts on the plant community may be caused by air movement associated with aircraft takeoffs and landings. Growth rates and leaf morphology may be affected by wind (Cleugh et al. 1998). In addition, lodging may occur (stem breakage or bending at the ground), dense foliage may be abraded through contact with other foliage, and soil particles that are lifted by wind may damage vegetation (Cleugh et al. 1998). A mechanistic model for stem breakage is presented in Sect. 4.1.2, though default values for the shear strength in the soil and the strength of stems are not easily found.

Thresholds for impacts of vibration are also presented in Sect. 4.1.3.11. What is missing is a method to relate impacts associated with vibrating the plants to effects from air movement.

Plant production depends on whether recovery is possible. Recovery is determined by the growth stage of the plant, soil and plant moisture status, plant species (Cleugh et al. 1998), and frequency of the stressor. 


\section{INTERMEDIATE RISK CHARACTERIZATION (7)}

The intermediate risk characterization is usually required to estimate risks to assessment endpoints that can cause indirect effects on secondary endpoints. The final risk characterization for indirect effects cannot be performed until intermediate risks are characterized. Two types of potential indirect effects of overflights were identified: 1) the effect of mortality or reduced production of prey organisms on populations of predators and 2) the effect of erosion and plant mortality on further erosion and plant mortality.

However, in both cases the direct effects cannot be estimated with sufficient confidence to extrapolate the results further to the estimation of indirect effects. 


\section{ACTIVITY-SPECIFIC RISK CHARACTERIZATION (8)}

\subsection{ESTIMATION OF RISKS (8.1)}

It is obvious that for low-altitude aircraft overflights, more information is available to estimate exposure than is available to estimate effects. Slant distance is a measure of exposure to acoustic and visual stressors. The software that has been developed to estimate sound pressure levels associated with flights by particular aircraft types at specific distances from an assessment endpoint organism is fairly sophisticated and useful, if models are available that relate responses of ecological receptors to sound. Observations of wildlife can contribute to the wildlife exposure assessment, though resources or equipment (e.g., radiotelemetry) may not be available at many installations. The largest gaps in knowledge are in exposureresponse models. Behavioral effects (flight, movement away from the aircraft) cannot be directly related to abundance or production of wildlife populations. In general, sparse information on effects does not permit the differentiation among aircraft types.

Using the methods below, a risk assessor can estimate risks from aircraft overflights to valued ecological receptors. The methods and models in the document are compatible with a decision support system, such as the Assessment System for Aircraft Noise (ASAN), a software tool designed to aid environmental planners in determining impacts of aircraft operations on the environment (FICAN 1998).

\subsubsection{Implementing Exposure-Response Models (8.1.1)}

In the risk characterization, the information in the exposure and effects profiles is combined to estimate risks. Guidance on the implementation of particular effects models for specific assessment endpoints is given in Sect. 4.3. More general guidance is provided here.

\subsubsection{Direct effects}

The best available method for estimating sound pressure levels at a given location is through noise contour software. The use of such software requires substantial information on flight schedules, types of aircraft, flight routes and altitudes, background sound levels, and environmental variables. Of course the noise contour output is only as good as the parameters that go into the model. For sound, the measure of exposure that is most often available from threshold models is the maximum sound level, so this should be an output for the noise contour model. The value may be A-weighted (adjusted to reflect human acoustic thresholds), because 1) appropriate weighting is not known for most wildlife species and 2) exposureresponse models, particularly thresholds, have been calculated on an A-weighted basis. Slant distance represents a measure of exposure to multiple stressors, Sect. 6.1.3. No models are available for estimating effects of the visual image of the aircraft without the sound.

The second component of exposure is the location of the individual wildlife. Are they randomly distributed through the affected area? Are fifty percent of the organisms located along a stream bank at any one time? Risk assessors do not typically invest much time and effort into this component of exposure analysis, but it is important for estimating impacts from overflights. In addition, the assessor should identify the spatial bounds on a population, compared to the bounds on the affected area. It is advisable for the assessor to develop a distribution of exposures of wildlife individuals. 
Models currently available for use in estimating the effects of sound from overflights on wildlife are not ideal. Most are threshold models, most relate to behavior rather than to endpoint properties, and most of these are expressed with respect to particular aircraft flying at a certain distance above or to the side of wildlife species. It is recommended that the assessor construct one or more distributions of effects thresholds that are relevant to the activity and endpoint. However, thresholds of sound pressure levels (e.g., maximum A-weighted levels) are few (Sect. 4.1.3). Thus, a distribution may simply consist of 2 data points.

Ultimately, if enough data are available, the risk characterization should consist of a comparison of distributions of exposure and those of probable effects for each assessment endpoint. Exposure and effects characterizations should have been performed with concordant spatial, temporal and intensity dimensions.

Effects models for 1) direct collisions with birds and 2) erosion and plant mortality have not been tested in the context of 1) military overflights, 2) all relevant endpoints, or 3) military (i.e., nonagricultural) lands. Clearly more testing of available models is needed for a comprehensive ecological risk assessment of low-altitude overflights.

\subsubsection{Indirect effects}

Models are required to determine 1) how decreased abundance or production of prey results in an effect on predators and 2) how decreased abundance or production of predators results in an effect on prey. Such models would be dependent on the site, region, and endpoint and would depend on food availability. For an effect on predators to be credible, it must be demonstrated that 1) there is a population-level impact on prey and $2 a$ ) that the predator is a selective feeder or $2 b$ ) that multiple prey populations are affected. This cannot be determined until the assessment for direct stressors is complete, but data compiled for this risk assessment framework for overflights suggests that it will be difficult to demonstrate and quantify a population-level effect on the endpoint species. Similar logic applies to exposure-response models for indirect effects on prey.

The effects of erosion on plant mortality and plant mortality on erosion would be derived from sites similar to the assessment site where aircraft take off and land. At the outset, the assessor can be certain that erosion and plant mortality will increase the other endpoint. The only model described above that relates productivity to erosion is the T-value, a soil loss threshold associated with a loss in productivity (Sect. 4.1.3.10). Both erosion and productivity losses are then estimated using agricultural models, which is not ideal for assessments of forests, pine barrens, arid ecosystems, etc.

\subsubsection{Weight of Evidence (8.1.2)}

In many predictive assessments only one line of evidence is available for the risk characterization of a stressor. However, if multiple measures of exposure exist, or if multiple empirical or mechanistic exposure-response models are available, all of these may be used to obtain a distinct estimate of risks to the assessment endpoints. One example from the previous section is the use of effects models based on distance (which integrates sound and the visual stressor) and those based on measured sound. In addition, site-specific effects data may be used as a line of evidence if similar overflights have previously been performed. 
Lines of evidence may be weighted differentially, if the assessor has more confidence in one than in another. The quality of a line of evidence depends on the inherent quality of the models employed and on the quantity and quality of data used to implement them. If differential weighting is implemented, the assessor should present the weights clearly. If results from different models are different and if lines of evidence are of significantly different quality, then the risk estimate from the highest quality line of evidence should be used. Ultimately, a determination should be made as to whether risk is likely for a particular endpoint and stressor combination. The following criteria may be used to weigh evidence (Suter et al. 2000):

1) Data relevance. Effects are relevant if the measured or estimated effect is a direct estimate of the assessment endpoint or if the estimated property is related to the assessment endpoint. The exposures at the installation must be similar to those in the exposure-response model, and the degree of similarity should contribute to the weighting. The assessor should list the ways in which exposures or test organisms are different from the endpoint.

2) Exposure-response relationship. The line of evidence is only useful if there is a relationship between exposure and response. If the magnitude or frequency of response is weakly related to slant distance, then the associated exposure-response model should be discounted in the weighting.

3) Temporal scope. The line of evidence is relevant if it is relevant to the conditions of interest. Models for nocturnal activities are not very relevant if overflights are during the day. Effects on spring migration are not relevant if all training will occur in the fall.

4) Spatial scope. Measurements of effects at the installation should match the affected area in spatial scope. Exposure-response models obtained from the literature should be representative of the assessment area.

5) Quality. Exposure and effects data should be evaluated in terms of the protocols for sampling, analysis and testing, the adequacy of quality control, the expertise of the investigators or field personnel, and the reasonableness of conclusions of individual studies.

6) Quantity. Data should be evaluated with respect to the number of observations. Results based on small sample sizes are given less weight than those based on large sample sizes. The adequacy of the number of observations should be considered in the context of 1) variance and 2) biases in sampling.

Weight-of-evidence results are typically presented in tabular format, with a line for each line of evidence and with a column entitled "result," where a plus (+) or minus (-) is written, depending on whether the evidence is suggestive of risk. For each endpoint, the summary risk judgment is also given. An example of a hypothetical risk characterization for a red-tailed hawk population exposed to overflight sound is provided in Table 21.

Table 21. A summary of risk characterization for the red-tailed hawk population exposed to sound associated with [name new night-time fixed-wing overflight training program] at [name installation].

\begin{tabular}{|c|c|c|c|c|}
\hline Evidence & $\begin{array}{c}\text { Resul } \\
\mathbf{t}\end{array}$ & $\begin{array}{c}\text { Confidence } \\
\text { in } \\
\text { Behavioral } \\
\text { Effect }\end{array}$ & $\begin{array}{c}\text { Confidence } \\
\text { in } \\
\text { Populatio } \\
\text { n-level } \\
\text { Effect }^{1}\end{array}$ & Explanation \\
\hline
\end{tabular}




\begin{tabular}{|l|l|l|l|l|}
\hline $\begin{array}{l}\text { Biological } \\
\text { survey }\end{array}$ & + & N. A. & Low & $\begin{array}{l}\text { Surveys indicate that the number of red-tailed hawks } \\
\text { nesting at the installation and the adjacent national } \\
\text { forest has decreased in the past 2 years that the } \\
\text { overflight training program has been in existence. }\end{array}$ \\
\hline $\begin{array}{l}\text { Slant- } \\
\text { distance/raptor } \\
\text { behavior } \\
\text { relationship }\end{array}$ & + & Moderate & Low & $\begin{array}{l}\text { The minimum slant distance between overflights and } \\
\text { birds is equivalent to the } 80^{\text {th }} \text { percentile of slant } \\
\text { distance thresholds associated with raptors flushing } \\
\text { from the nest in daylight. Most data are from } \\
\text { rotary-wing aircraft. }\end{array}$ \\
\hline $\begin{array}{l}\text { Sound } \\
\text { level/raptor } \\
\text { behavior } \\
\text { relationship }\end{array}$ & - & Moderate & Low & $\begin{array}{l}\text { The sound levels at nest level which are predicted by } \\
\text { Routemap software are lower than the minimum } \\
\text { threshold sound level from overflights which is } \\
\text { associated with raptors flushing from the nest. }\end{array}$ \\
\cline { 2 - 5 } & Moderate & Low & $\begin{array}{l}\text { The sound levels measured at three nests are lower } \\
\text { than the minimum threshold sound level from } \\
\text { overflights which is associated with raptors flushing } \\
\text { from the nest. }\end{array}$ \\
\hline & Moderate & Low & $\begin{array}{l}\text { Comparable sound levels from night-time artillery } \\
\text { testing at a neighboring base never elicit a flush } \\
\text { response by red-tailed hawks. Higher sound levels } \\
\text { from artillery elicit a response during the day but } \\
\text { not at night. }\end{array}$ \\
\hline $\begin{array}{l}\text { Weight of } \\
\text { evidence }\end{array}$ & - & $\begin{array}{l}\text { The weight of evidence suggests that the new } \\
\text { training program is probably not responsible for } \\
\text { raptors flushing from nests. No direct evidence } \\
\text { indicates effects of sound on abundance or } \\
\text { production of hawks at the site. To lead to effects } \\
\text { on abundance and production, flushing birds would } \\
\text { have to miss feedings, abandon nests, etc. Sound } \\
\text { from fixed-wing aircraft does not appear to be } \\
\text { responsible for the decrease in the red-tailed hawk } \\
\text { population. }\end{array}$ \\
\hline
\end{tabular}

${ }^{1}$ Level of confidence in population-level effect is lower than level of confidence in behavioral effect.

Lines of evidence are weighed differently in Table 21. The survey of hawks is a weak line of evidence, because cause and effect has not been established. The slant distance line of evidence would be strong if: 1) a 20 percent or lower level of effects was determined in the problem formulation to indicate a significant effect, 2) the relationship between behavioral and population-level effects was understood, 3) the flights occurred in daylight (making the visual component of the stressor important and reaction to sound more probable), and 4) the relationship included more data from fixed-wing aircraft. Assuming that the studies of sound were somewhat rigorous, they provide the best evidence about the effects of sound from these overflights on hawk behavior. Although the level of confidence that a population-level effect is indicated is lower than the level of confidence that a behavioral effect is indicated (Table 21), the lack of a behavioral effect probably signifies the lack of a population-level effect.

\subsubsection{Multiple Stressors and Activities (8.1.3)}


If risks to a particular activity are a product of multiple stressors or multiple modes of action, these modes must be combined in a common model that may be used to estimate risks. There are four major issues:

- How should multiple modes of action of a single stressor generated by aircraft overflights be combined?

- How should impacts of multiple stressors generated by aircraft overflights be combined?

- What other military activities are likely to co-occur with overflights in a training or testing program and how should they be combined with the effects of overflights?

- What environmental stressors occur with overflights, and how should they be combined with the effects of overflights?

\subsubsection{Multiple modes of action of a single stressor}

This type of model is pertinent if the stressor produces direct effects on abundance and behavioral responses that result in indirect effects on abundance. Models must be developed to relate both modes of action to the assessment endpoint.

\subsubsection{Multiple stressors}

Stressors associated with overflights are described in Sect. 2.1.3. These include: sound, the visual image of the aircraft, the physical aircraft (collision), air movement, and heat, which may generally be ignored.

Two stressors often act together: sound from the aircraft and the visual image of the aircraft; an exception is if the aircraft is not seen by the endpoint organism. Empirical models that relate slant distance or altitude to response already incorporate these two stressors. Only birds are affected by the direct collision stressor. Collision with birds is independent of sound and view of the aircraft; if a bird is hit by an aircraft, it does not matter whether the bird would have experienced additional stress from the sound. The effect of collision is mortality, which is a direct measure of the abundance endpoint. Models to estimate population abundance, based on flushing behavior, are required if impacts of collision and the sound/aircraft image stressors are to be added.

Soil erosion and air movement (e.g. rotor wash) are independent of sound, the image of the aircraft, and collision with birds.

\subsubsection{Multiple, co-occurring activities}

Military activities that frequently co-occur with low-altitude aircraft overflights are listed in Sect. 2.1.1.7. The National Environmental Policy Act requires that cumulative impacts, i.e., the "impact on the environment resulting from the incremental impact of the action when added to other past, present, or foreseeable future actions" be estimated (Council on Environmental Quality 1978). As stated above, for the impacts of these activities to be added to the effects of the five stressors associated with overflights, both must be translated into effects on the assessment endpoints, abundance or production. Additional training and testing activities, such as tank training, troop movement, fuel spills, ground run-ups of engines, and 
missile testing would have to be divided into constituent stressors before effects could be estimated and added to effects of overflights. A generic framework for assessment of ecological risks from multiple activities is presented in Suter (1999) and Suter et al. (1998), and only a few key points related to overflights are summarized here.

Effects of sounds associated with training are more easily added to effects of overflights if sound pressure levels are the exposure metric in both models. Thus, it may sometimes be advisable for distance thresholds to be translated to the equivalent sound thresholds. If sounds are simultaneous, then decibel levels should be added using the formula in Sect. 2.5. This addition is easy if the exposure metric is a daynight averaged sound level. However, the $\mathrm{L}_{\mathrm{dn}}$ is not usually related to behavioral or reproductive effects. More important is whether or not two sounds occur at or near the same time. Probabilistic models may be developed to estimate how often sounds are likely to coincide, if their frequencies and durations are known. A model is under development that would integrate continuous noise signatures and impulsive noise signatures to estimate noise contour levels (J. Fittipaldi, 3/98, pers. comm.)

Co-occurring activities such as tank training and troop movement could damage habitat. In poor habitat, the flight of organisms could lead to less food and reduced production. Moreover, a model has been developed to simulate how the spatial distribution of nesting habitat affects the reproductive success of territorial migrant avian species breeding in fragmented, patchy landscapes (Dale et al. 1998). The model was designed for areas disturbed by military activities.

If effects of a certain type (e.g. fecundity of a population) that are associated with one stressor are much greater than other contributors to those effects, the small contributors may be dismissed with justification. This is particularly true for stressors on a logarithmic scale, such as sound. The increment in risk obtained by including the negligible mode of action would be smaller than the uncertainty concerning the significant stressor.

If multiple activities are included in a program, then there may be site-specific exposure-response models that incorporate all stressors. For example, changes in coyote (Canis latrans) movements associated with a variety of activities (battlefield simulations involving fixed-wing and rotary-wing aircraft overflights, tanks, armored personnel carriers, trucks and jeeps) were observed (Gese et al. 1989).

\subsubsection{Natural stressors}

Risks from overflights must be considered in the context of natural stressors. These could include hurricanes and tornadoes, which could damage habitat and reduce food availability to wildlife who have been startled away from the overflight locations.

Several natural disturbances have been cited in the literature as having a role in effects of overflights. These include: 1) wintertime harassment of caribou by insects (Maier et al. 1998), 2) drought affecting the population of Mojave fringe-toed lizard (Uma scoparia) (Brattstrom and Bondello 1983).

\subsection{ESTIMATE UNCERTAINTY AND VARIABILITY (8.2)}

In any risk assessment, sources of variability and uncertainty in results must be described and quantified. Sources of uncertainty and variability may be associated with both exposure estimates and 
effects estimates. Some of these uncertainties that are independent of the site are described below. Clearly, the risk estimate for any stressor and endpoint combination for which few data exist is highly uncertain.

\subsubsection{Uncertainties in Estimates of Exposure}

Uncertainties associated with outputs of the noise contour generation model include: measurement error in model input values and model error. Uncertainties associated with the output include all of the variables that affect sound propagation that are not included in the model. For example, MR_NMAP does not include wind, ground topography, or day-to-day variations in meteorological conditions (USAF 1998). Some of the errors are quantified; for example, topographic features can sometimes cause momentary increases in sound levels (reflections) of up to $3 \mathrm{~dB}$ for brief periods and can sometimes decrease sound substantially (shielding) often more than $20 \mathrm{~dB}$ (USAF 1998). Also, since altitude is calculated on the bases of the highest local ground elevation, the altitude relative to a canyon bottom is underpredicted. When sound is propagated in the model through distances greater than one or two $\mathrm{km}$, atmospheric absorption and lateral attenuation can lead to large uncertainties (USAF 1998). Sound level predictions of MR_NMAP are accurate to within a few decibels if sound levels are greater than $55 \mathrm{~dB}$ (USAF 1998). Variability in model output may be quantified by propagating variability in input parameters through the model. One method is the use of Monte Carlo simulation, which is already built into a component of MOAMAP (Dept. of the Air Force 1995).

The use of A-weighted (based on the human hearing frequency range) measured or estimated sound pressure levels noise leads to uncertain estimates of wildlife exposure to sound from overflights. Also, the more a sound exceeds the $60 \mathrm{~dB}$ sound pressure level, the less the A-weighted value simulates the spectral selectivity of human hearing (Berglund et al. 1990).

Estimates of the distance of an overflight from the ground, nests, particular wildlife, or flying birds that are the basis of some threshold effects models are typically measured with some uncertainty. Often the pilot, scientist, or other measurer is able to estimate the degree of uncertainty. For example, in an extensive study of raptors, passes greater than $200 \mathrm{~m}$ were believed to be accurate to $25 \%$ (Ellis et al. 1991). The extent to which lateral distance or altitude is used to estimate slant distance contributes to uncertainty in exposure.

Substantial uncertainty may result from the estimation of locations of wild-ranging or migratory wildlife at the time of the overflight event. The uncertainty may be stochasticity, if probabilistic models of the whereabouts of individuals at a particular time, day or season can be developed. Otherwise, simple assumptions may be made, such as that any individual has an equal chance of being at any location on the site at any time. Then of course the definition of the boundaries of the site is important. The measurements of locations of individual wildlife through the use of radiotelemetry may be inaccurate if observation rates are higher in particular habitat types, particularly where canopy cover differs. Uncertainties associated with radiotelemetry are discussed in Johnson et al. (1998).

Pilot reports of bird strike rates are often biased, so this uncertainty must be considered if

interviews are used to generate data. For example, Linnell et al. (1999) found that only $25 \%$ of bird strikes at a Hawaiian airport were reported, and the actual reporting rate depended on season, time of day, season, and number of birds killed.

\subsubsection{Uncertainties in Exposure-response Models}


Uncertainty arises from the extrapolation of exposure-response models from one location to another. When site-related variables on which the effects depend are not part of the model, there is uncertainty associated with the results of the model. Often the applicability of a model from one site to another is not known. For example, temporal distributions of bird strikes at different commercial airports (JFK and Lihue) do not correspond (Linnell et al. 1996).

One source of uncertainty arises from the way in which sound is generated in studies from which exposure-response models are derived. For example, in some studies, white noise is generated in animal pens and applied continuously for a period of time. In others, recorded motorcycle or dune buggy noise is played. These models are not easily extrapolated to an actual overflight event or multiple overflights. Sekyra et al. (1975) list several factors that contribute to measurement variability of sound (e.g., choice of microphones, orientation and calibration of measurement, and synchronization of position and acoustic data). In addition, acoustic noise monitors may be inaccurate during windy conditions.

The primary source of uncertainty in the estimate of effects is in the extrapolation among species and locations. As more research fills in these gaps, this uncertainty will be reduced.

The primary source of uncertainty in the estimate of effects is in the extrapolation among species and locations. The range of sensitivities of classes of organisms can be depicted in species sensitivity distributions, but it is not clear that effects thresholds are necessarily closer for animals that are more closely related. (Note the wide variance in slant distance thresholds among walruses in Fig. 4) The magnitude of uncertainty in slant distance thresholds for pinnipeds is about an order of magnitude (Fig. 4); the magnitude is somewhat higher for raptors (Table 14) and ungulates (Table16).

Differences in effects that are dependent on the organism's activities at the time (foraging, mating, sleeping) contribute to uncertainty and should be included in the uncertainty analysis, because such activityspecific models are rare.

Where empirical effects models (e.g., regressions) are used, it is important to note: a) the population on which the model was tested and $b$ ) the variation that is explained by the independent variable of concern. For example, although frequency of overflights explained about half of the variability in movement of barren-ground caribou, the rest of the variation was probably due to snow depth, temperature, precipitation, wind speed, body condition, pregnancy status, habitat quality and availability, group size, and insect harassment (Maier et al. 1998). 


\section{CONCLUSIONS}

This framework for the assessment of risks from aircraft overflights to natural resources is intended to be widely applicable to military services conducting diverse training activities in various locations. It is also applicable to civilian activities, such as tourist flights or aerial surveys that involve low-altitude operation of aircraft in ecologically sensitive areas.

\subsection{PROBLEM FORMULATION}

The key stressor for low-altitude, military aircraft overflights is usually sound, although the visual and physical (collision) stressors are also sometimes significant. In addition, air movement may be a significant stressor for plant communities in a localized area. The primary assessment endpoint entities are wildlife that are highly exposed and rather sensitive to sound. One of the challenges of the problem formulation is to obtain an accurate description of the training or testing activity.

\subsection{CHARACTERIZATION OF EXPOSURE}

The primary measurements of exposure that would be useful for risk assessments for overflights would be: measurements of locations of wildlife, measurements of sound levels at the locations of wildlife, and measurements of slant distances from wildlife. The chief models for estimating exposure from aircraft overflights include 1) models that extrapolate sound from the source aircraft to the ground to produce noise contours and 2) bird strike probability models.

\subsection{CHARACTERIZATION OF EFFECTS}

The analysis of effects for aircraft overflights presents large uncertainties in the quantitative assessment of the abundance and production of wildlife. Studies of effects of aircraft overflights have not been associated with a quantitative assessment framework; therefore no consistent relationships between exposure and population-level response have been developed. In general, there is a moderate amount of information on behavioral effects associated with overflights, but little on abundance and reproduction. Moreover, models that relate behavioral changes to abundance or reproduction, and those that relate behavioral or hearing effects thresholds from one population to another are generally not available. Also, responses are highly dependent on activities that animals were previously engaged in, as well as previous exposures to overflights. The most precise exposure metric is probably a sound metric such as the maximum sound pressure level, but most of the exposure-response models relate effects to slant distance, which incorporates the visual stressor as well as the acoustic stressor.

Thus, the assessor is forced to choose between 1) a minimal to nonexistent set of exposureresponse models that directly relate sound or slant distance to population parameters and 2) a moderately large set of models that relate the exposure metrics to behavior. The assessor is confronted with the problem of weighing data relevance against quantity of data in deciding whether distributions of thresholds should include: all aircraft or just rotary-wing, all raptors or just bald eagles, all sites or just a single Air Force Base, all overflights or just nighttime measurements, etc. 


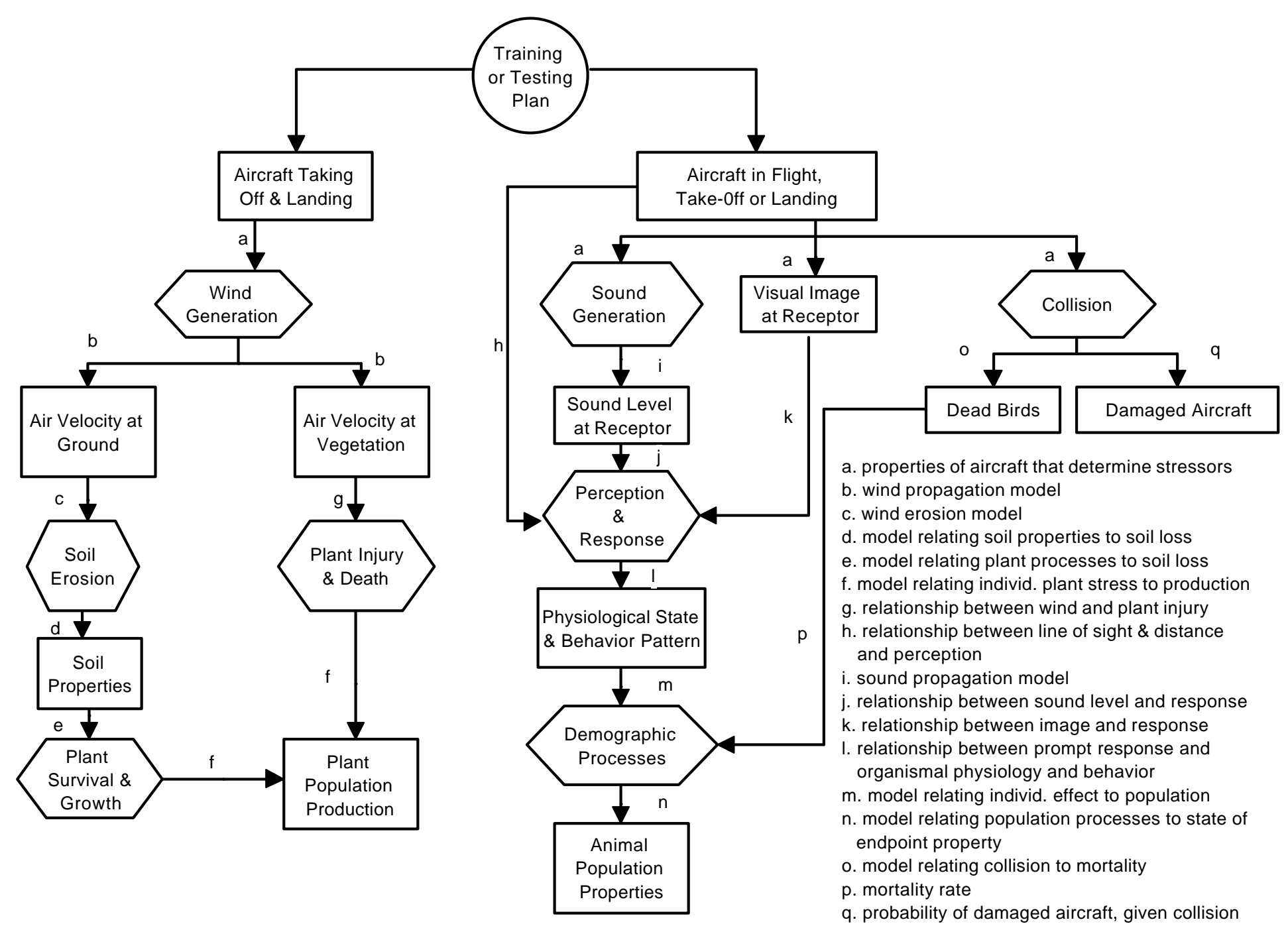

Figure 1. Generic conceptual model for ecological risk assessment framework for aircraft overflights. 


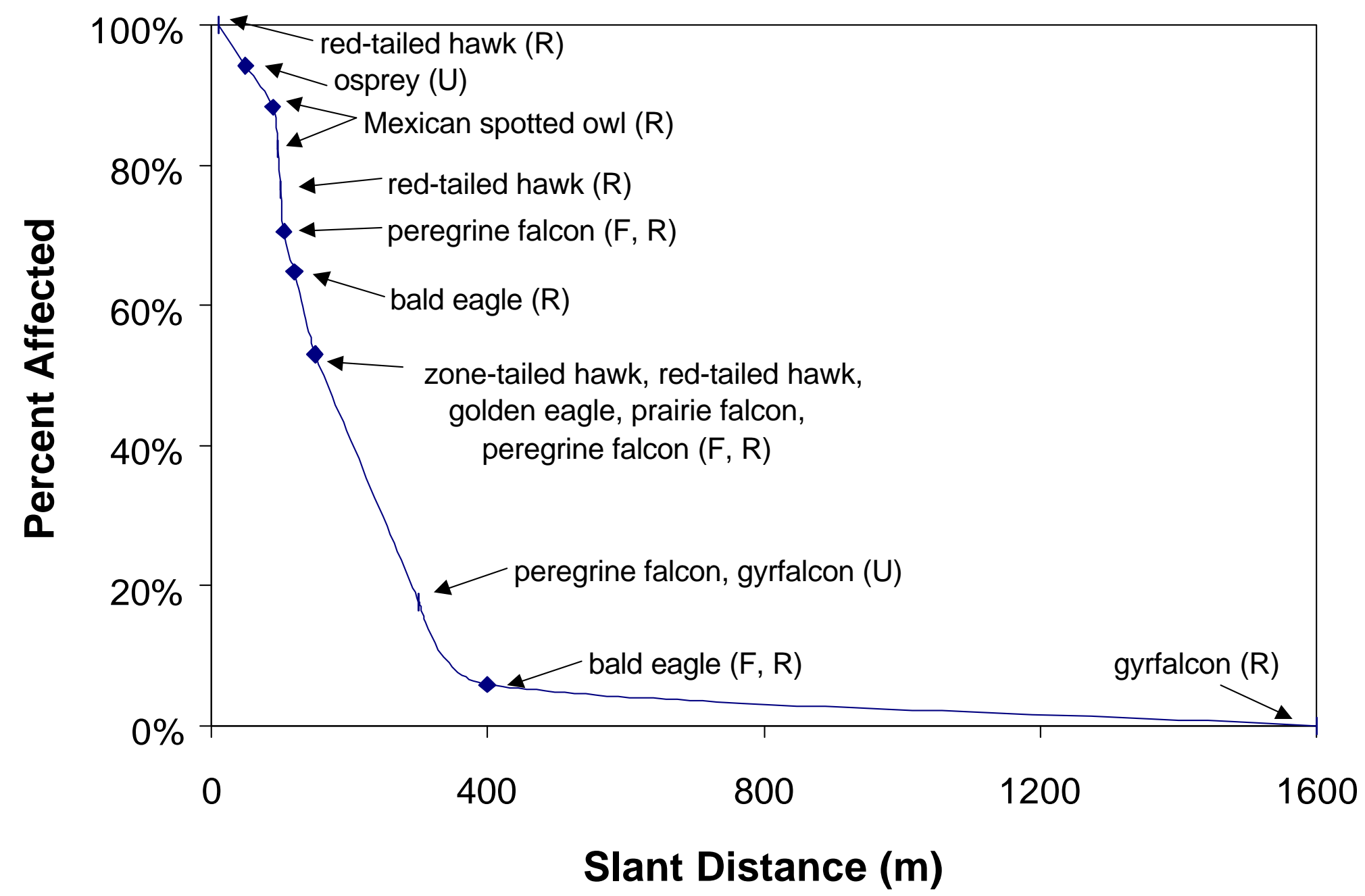

Figure 2. Distribution of slant distance thresholds for behavioral effects on raptors from various aircraft. F, R, and U indicate that effects are due to fixed-wing, rotary-wing and unknown aircraft, respectively. 


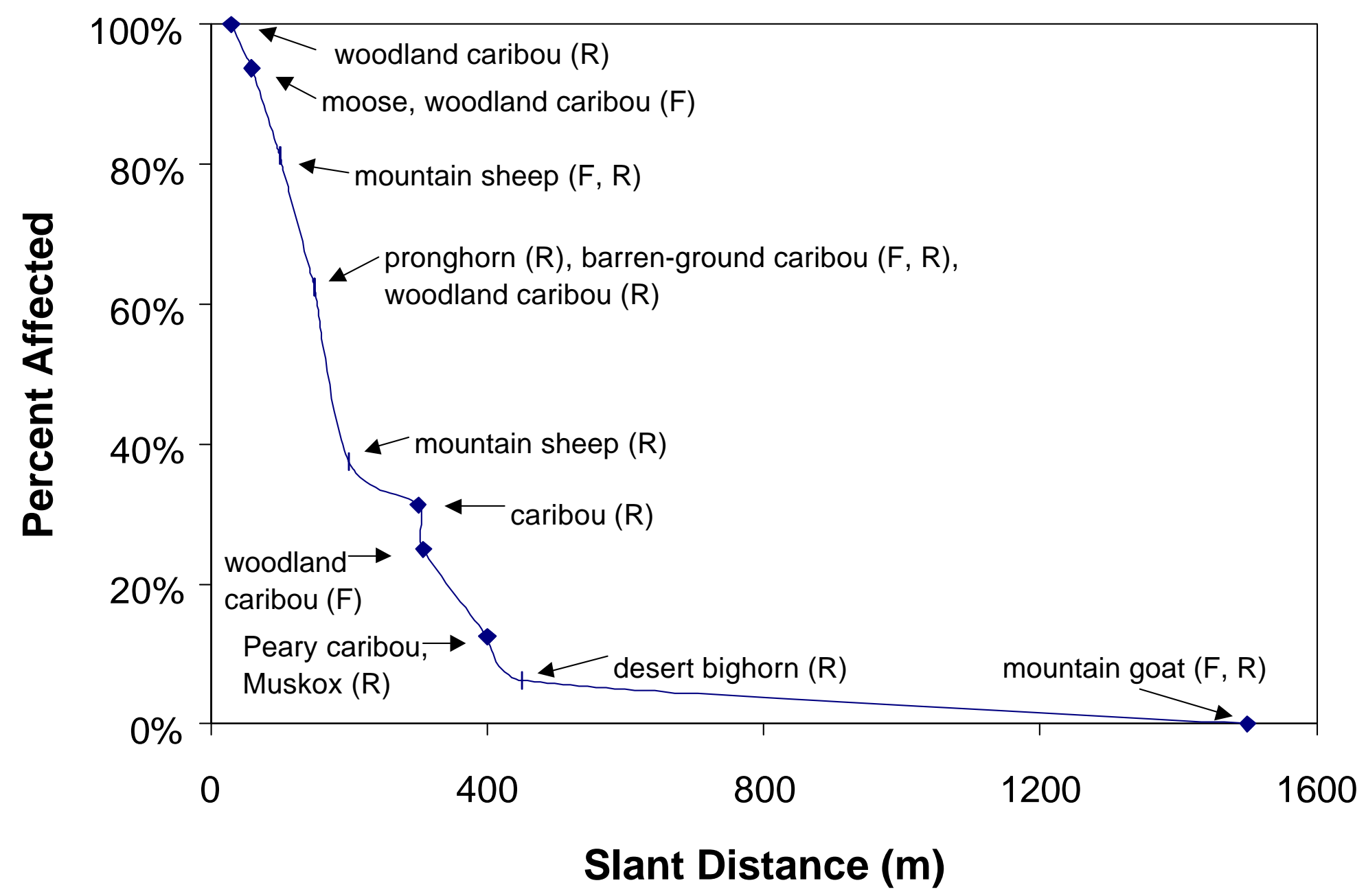

Figure 3.

Distribution of slant distance thresholds for behavioral effects on ungulates from various aircraft. F and $\mathrm{R}$ indicate that effects are due to fixed-wing and rotary-wing, respectively. 


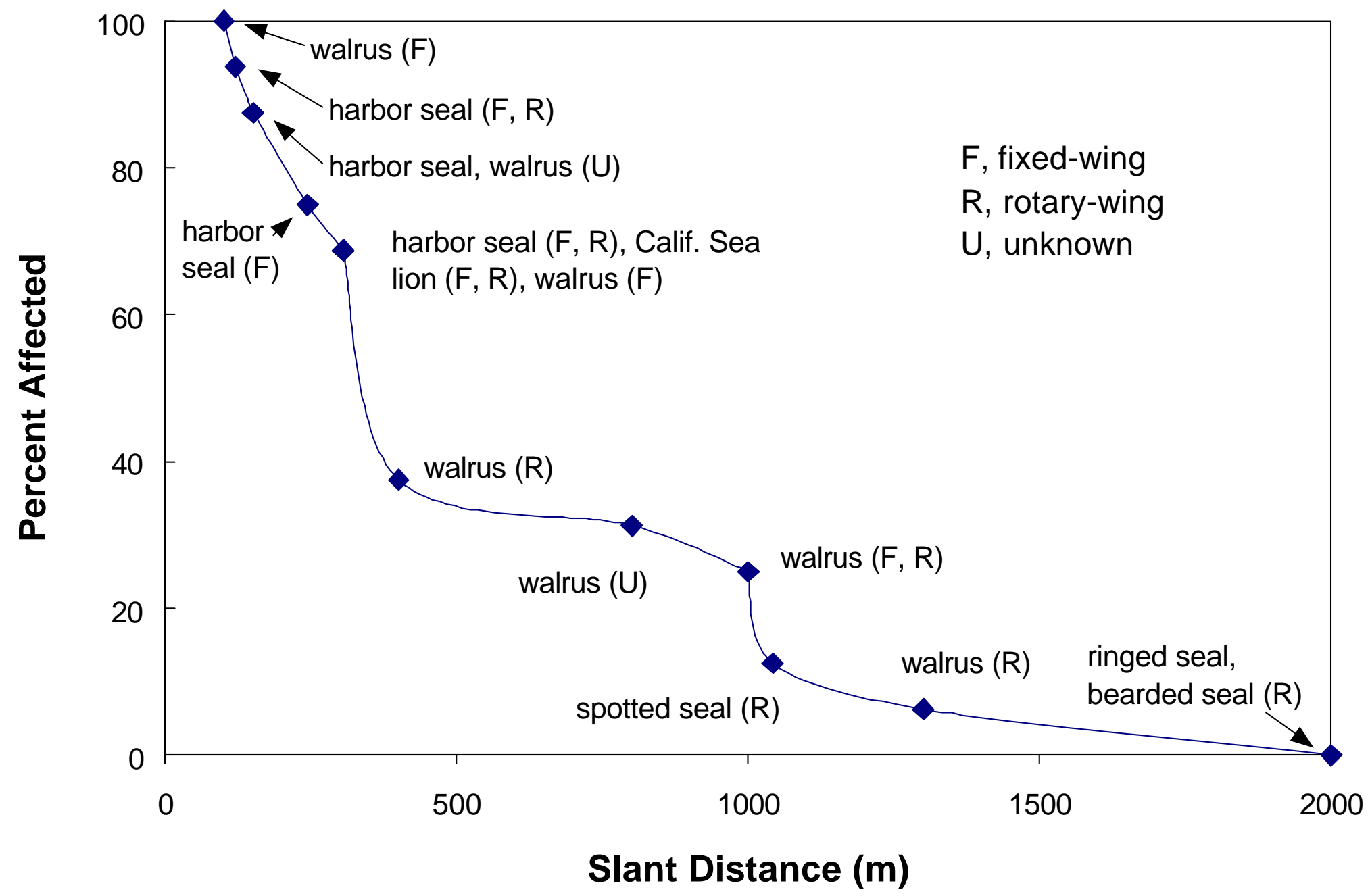

Figure 4. Distribution of slant distance thresholds for behavioral effects on pinnipeds (seals, sea lions, walruses) from various aircraft. Thus, at a slant distance of $1000 \mathrm{~m}, 25 \%$ of hauled out groups of pinnipeds are affected by aircraft overflights. F, R, and U indicate that effects are due to fixed-wing, rotary-wing and unknown aircraft, respectively. 


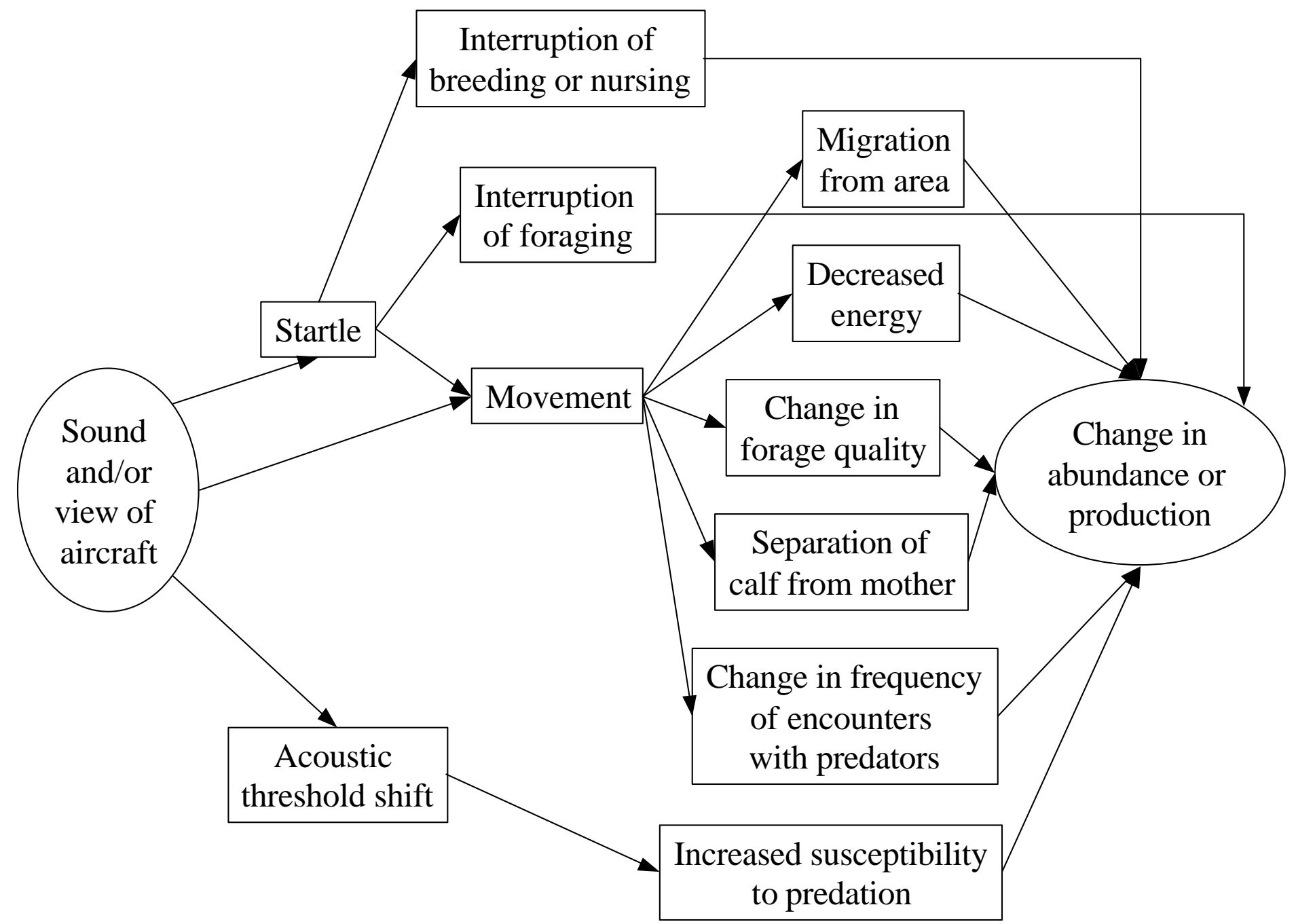

Figure 5. Diagram illustrating the relationship between the direct mechanisms of action of the sound and visual stressors from aircraft overflights and population-level effects on ungulates (hoofed mammals). Each arrow signifies a probability (that is assumed to be less than one) or function. Most of these relationships have not been quantified, and factors such as season or current activity of an individual may contribute to the relationship. 


\section{REFERENCES}

Air National Guard. 1997. Final Environmental Impact Statement for the Colorado Airspace Initiative, Vol. 1. Impact Analyses. National Guard Bureau, Andrews Air Force Base, MD.

Ames, D. R. 1978. Physiological responses to auditory stimuli: pp. 23-45. J. L. Fletcher and R. G. Busnel (eds.), Effects of Noise on Wildlife. Academic Press, New York.

Andersen, D. E., O. J. Rongstad and W. R. Mytton. 1989. Response of nesting red-tailed hawks to helicopter overflights. Condor 91:296-299.

$\mathrm{Au}, \mathrm{D}$. and W. Perryman. 1982. Movement and speed of dolphin schools responding to an approaching ship. Fish. Bull. 80(2):371-379.

Awbrey, F. T. 1980. Sound spectra on San Miguel Island, 1979-1980, pp. 229-246. In J. J. R. Jehl and C. F. Cooper (eds.), Potential Effects of Space Shuttle Sonic Booms on the Biota and Geology of the California Channel Islands: Research Reports. Tech. Rep. 80-1. Cent. Mar. Stud., San Diego State Univ. and Hubbs/Sea World Res. Inst. for U. S. Air Force, Space Div., San Diego, CA.

Awbrey, F. T. and A. E. Bowles. 1989. The Effects of Aircraft Noise and Sonic Booms on Raptors: A Preliminary Model and A Synthesis of the Literature on Disturbance. NSBIT Technical Operating Report No. 12. United States Air Force Air Force Systems Command, Wright-Patterson Air Force Base, $\mathrm{OH}$.

Batie, S. S. 1983. Soil Erosion: Crisis in America's Croplands? The Conservation Foundation, Washington, D. C.

Belanger, L. and J. Bedard. 1990. Energetic cost of man-induced disturbance to staging snow geese. J. Wildl. Manage. 54(1):36-41.

Bel'kovich, V. M. 1960. Some biological observations on the white whale from the aircraft. Zool. Zh. 39(9):1414-1422, as cited in Richardson et al. 1995.

Berglund, B., T. Lindvall and S. Nordin. 1990. Adverse effects of aircraft noise. Environment International 16:315-338.

Bleich, V. C., R. T. Bowyer, A. M. Pauli, M. C. Nicholson and R. W. Anthes. 1994. Mountain sheep Ovis canadensis and helicopter surveys: ramifications for the conservation of large mammals. Biolog. Conserv. 70:1-7.

Bleich, V. C., R. T. Bowyer, A. M. Pauli, R. L. Vernoy and R. W. Anthes. 1990. Responses of mountain sheep to helicopter surveys. Calif. Fish and Game 76(4):197-204.

Blix, A. S. and J. W. Lentfer. 1992. Noise and vibration levels in artificial polar bear dens as related to selected petroleum exploration and developmental activities. Arctic 45(1):20-24.

Blokpoel, H. 1973. Bird Migration Forecasts for Military Air Operations. Occasional Paper Number 16. Canadian Wildlife Service, Ottawa, Canada.

Bondello, M. C. 1976. The Effects of High-Intensity Motorcycle Sounds on the Acoustical Sensitivity of the Desert Iguana, Dipsosaurus dorsalis. Fullerton, CA, California State University. 38pp., as cited in Brattstrom and Bondello, 1983.

Bowles, A. E., S. A. Eckert and L. Starke. 1997a. Effects of simulated sonic booms and low-altitude aircraft noise on the behavior and heart rate of the desert tortoise (Gopherus agassizii). The Desert Tortoise Council. Abstracts for the Twenty-Second Annual Meeting and Symposium, Las Vegas, NV.

Bowles, A. E., J. K. Francine, J. Matesic Jr. and H. Stinson. 1997b. Effects of simulated sonic booms and low-altitude aircraft noise on the hearing of the desert tortoise (Gopherus agassizii). The Desert Tortoise Council. Abstracts for the Twenty-Second Annual Meeting and Symposium, Las Vegas, NV. 
Bowles, A. E., L. McClenaghan, J. K. Francine, D. Wisely, R. Bolightly and R. Kull. 1993. Effects of aircraft noise on the predator-prey ecology of the kit fox (Vulpes macrotis) and its small mammal prey. Noise \& Man '93: Noise as a Public Health Problem, Nice, France, Institut National de Recherche sur les Transports et leur Securite.

Bowles, A. E. and B. S. Stewart. 1980. Disturbances to the pinnipeds and birds of San Miguel Island, 1979-1980: pp. 99-137. J. J. R. Jehl and C. F. Cooper (eds.), Potential Effects of Space Shuttle Sonic Booms on the Biota and Geology of the California Channel Islands: Research Reports. Tech. Rep. 80-1. Cent. Mar. Stud., San Diego State Univ. and Hubbs/Sea World Res. Inst. for U. S. Air Force, Space Div., San Diego, CA

Brady, N. C. 1974. The Nature and Properties of Soils. Macmillan Publishing, Co., New York.

Brattstrom, B. H. and M. C. Bondello. 1983. Effects of off-road vehicle noise on desert vertebrates: pp. 167-206. R. H. Webb and H. G. Wilshire (eds.), Environmental Effects of Off-road Vehicles. Springer-Verlag, New York.

Breininger, D. R., V. L. Larson, B. W. Duncan and R. B. Smith. 1998. Linking habitat suitability to demographic success in Florida scrub-jays. Wildl. Soc. Bull. 26:118-128.

Brooks Air Force Base. 1996. Requirements for Analysis of Noise. Final Report. http://xre22.brooks.af.mil/hscxre/RAsTAs/NOISEFNL.htm\#HUMAN. U. S. Air Force Human Systems Center, Environmental Planning Directorate, Brooks Air Force Base, TX.

Brown, A. L. 1990. Measuring the effect of aircraft noise on sea birds. Environment International 16:587-592.

Brueggeman, J. J., C. I. Malme, R. A. Grotefendt, D. P. Volsen, J. J. Burns, D. G. Chapman, D. K. Ljungblad and G. A. Green. 1990. 1989 Walrus Monitoring Program: the Klondike, Burger, and Popcorn Prospects in the Chukchi Sea. EBASCO Environmental for Shell Western E \& P Inc., Houston, TX, as cited in Richardson et al. 1991.

Burger, J. 1981. Behavioral responses of herring gulls Larus argentatus to aircraft noise. Environ. Pollut. (Ser. A) 24:177-184.

Burger, J. 1998. Antipredator behaviour of hatchling snakes: effects of incubation temperature and simulated predators. Animal Behaviour 56:547-553.

Busnel, M. C. and D. Molin. 1978. Preliminary results of the effects of noise on gestating female mice and their pups: pp. 209-248. J. L. Fletcher and R. G. Busnel (eds.), Effects of Noise on Wildlife. Academic Press, New York.

Calef, G. W., E. A. DeBock and G. M. Lortie. 1976. The reaction of barren-ground caribou to aircraft. Arctic 29:201-212.

CCRT (Center for Conservation Research and Technology). 1998. Resource Managers' Technical Review: Advanced Technologies for the Conservation of Biodiversity, Habitats, and Ecosystems. CCRT, Baltimore.

CHABA (Committee on Hearing Bioacoustics and Biomechanics) Working Group 69. 1977. Guidelines for Preparing Environmental Impact Statements on Noise. National Academy of Sciences, Washington, D. C.

Chapman, J. A. and G. A. Feldhamer. 1982. Wild Mammals of North America : Biology, Management, and Economics. Johns Hopkins University Press, Baltimore.

Chesser, R. K., R. S. Caldwell and M. J. Harvey. 1975. Effects of noise on feral populations of Mus musculus. Physiolog. Zool. 48(4):323-325.

Clark, C. W. 1998. Impact of man-made low-frequency sound on marine mammals. Partners in Environmental Technology 98, Arlington, VA, Strategic Environmental Research and Development Program and Environmental Security Technology Certification Program. 
Clarke, J. T., S. E. Moore and D. K. Ljungblad. 1989. Observations on gray whale (Eschrichtius robustus) utilization patterns in the northeastern Chukchi Sea, July-October 1982-1987. Can. J. Zool. 67(11):2646-2654.

Cleugh, H. A., J. M. Miller and M. Bohm. 1998. Direct mechanical effects of wind on crops. Agroforestry Systems 41:85-112.

Congressional Budget Office. 1995. An Analysis of U. S. Army Helicopter Programs. Congress of the United States, Washington, D. C.

Conomy, J. T., J. A. Dubovsky, J. A. Collazo and W. J. Fleming. 1998. Do black ducks and wood ducks habituate to aircraft disturbance? J. Wildl. Manage. 62(3):1135-1142.

Côté, S. D. 1996. Mountain goat responses to helicopter disturbance. Wildl. Soc. Bull. 24(4):681-685.

Council on Environmental Quality. 1978. Regulations for Implementing the Procedural Provisions of the National Environmental Policy Act. 40CFR Parts 1500-1508 (as of July 1, 1986).

Craig, T. H. and E. H. Craig. 1984. Results of a helicopter survey of cliff-nesting raptors in a deep canyon in southern Idaho. J. Raptor Res. 18:20-25.

Dale, V. H., T. L. Ashwood, A. W. King, L. K. Mann, M. Turner, M. A. Smith, L. G. Pollack, T. T. Wilder, T. A. Beaty and R. N. Kickert. 1998. Spatially Explicit Ecological Models for Land-Use Decisions: Examples for Military Land Management. Oak Ridge National Laboratory, Strategic Environmental Research and Development Program, Oak Ridge, TN.

Delaney, D. K., T. G. Grubb, P. Beier, L. L. Pater and M. H. Reiser. 1999. Effects of helicopter noise on Mexican spotted owls. J. Wildl. Manage. 63(1):60-76.

Derksen, D. V., K. S. Bollinger, D. Esler, K. C. Jensen, E. J. Taylor, M. W. Miller and M. W. Weller. 1992. Effects of Aircraft on Behavior and Ecology of Molting Black Brant near Teshekpuk Lake, Alaska. OCS Study MMS 92-0063. U. S. Fish and Wildlife Service and Dept. of Wildlife and Fisheries Sciences, Texas A\&M University for U. S. Bureau of Land Management and U. S. Minerals Management Service, Anchorage, AK.

Defenders of Wildlife. 1994. Unfriendly Skies: The Threat of Military Overflights To National Wildlife Refuges. Washington, D. C. www.rama-usa.org/skies.htm.

Dohl, T. P., R. C. Guess, M. L. Duman and R. C. Helm. 1983. Cetaceans of Central and Northern California, 1980-1983: Status, Abundance, and Distribution. NTIS PB85-183861. Cent. Coastal Mar. Stud., Univ. Calif., Santa Cruz for U. S. Minerals Manage. Serv., Los, Angeles, CA, as cited in Richardson et al. 1991.

Dunnet, G. M. 1977. Observations on the effects of low-flying aircraft at seabird colonies on the coast of Aberdeenshire, Scotland. Biolog. Conserv. 12:55-63.

Eckert, S. A., A. E. Bowles and L. Starke. 1997. Effects of jet aircraft flight noise on the heart rate and metabolic rate of the desert tortoise (Gopherus agassizii). The Desert Tortoise Council. Abstracts for the Twenty-Second Annual Meeting and Symposium, Las Vegas, NV.

Edwards, R. G., A. B. Broderson, R. W. Barbour, D. F. McCoy and C. W. Johnson. 1979. Assessment of the environmental compatibility of differing noise certification standards. Final Report. FAAAEE-19-13. Department of Transportation, unknown city, WA, as cited in Awbrey and Bowles 1979.

Ehret, G. 1977. Comparative psychoacoustics: perspectives of peripheral sound analysis in mammals. Naturwissenschaften 64:461-470.

Ellis, D. H., C. H. Ellis and D. P. Mindell. 1991. Raptor responses to low-level jet aircraft and sonic booms. Environ. Pollut. 74:53-83.

EPA. 1980. Effects of Noise on Wildlife and Other Animals: Review of Research Since 1971. EPA 550/9-80-100. U. S. Environmental Protection Agency, Office of Noise Abatement and Control, Washington, D. C. 
EPA. 1993. Wildlife Exposure Factors Handbook. EPA/600/R-93/187. U. S. Environmental Protection Agency, Office of Research and Development, Washington, D. C.

EPA. 1998. Guidelines for Ecological Risk Assessment. EPA/630/R-95/002F. Risk Assessment Forum, U. S. Environmental Protection Agency, Washington, D. C.

Erlich, P. R., D. S. Dobkin and D. Wheye. 1988. The Birder's Handbook : A Field Guide To the Natural History of North American Birds : Including All Species That Regularly Breed North of Mexico. Simon \& Schuster, New York.

FAA (Federal Aviation Administration). 1985. Aviation Noise Effects. ADA-154319. U. S. Department of Commerce, National Technical Information Service, Washington, D. C.

FAA (Federal Aviation Administration). 1998. INM Pre-Approved List of Aircraft Substitutions. www.aee.faa.gov/aee-100/aee-120/inm/inm52/geninfo.htm.

Fay, F. H. 1981. Modern populations, migrations, demography, trophics, and historical status of the Pacific walrus. I: pp. 191-234. Environ. Assess. Alaskan Cont. Shelf, Annu. Rep. Princ. Invest. NOAA, Boulder, CO, as cited in Richardson et al. 1995.

Fay, F. H., B. P. Kelly, P. H. Gehnrich, J. L. Sease and A. A. Hoover. 1986. Modern populations, migrations, demography, trophics, and historical status of the Pacific walrus. 37: pp. 231-376. Outer Cont. Shelf Environ. Assess. Program. Final Rep. Princ. Invest. OCS Study MMS. NOAA, Anchorage, AK, as cited in Richardson et al. 1991.

FICAN (Federal Interagency Committee on Aviation Noise). 1998. Aviation Noise Research Conducted by FICAN Member Agencies. Prepared by Harris Miller Miller \& Hanson Inc. for the Federal Aviation Administration.

Fleishner, T. and S. Weisberg. 1986. Effects of Jet Aircraft Activity on Bald Eagles in the Vicinity of Bellingham International Airport. Report for DEVCO Aviation Consultants, as cited in Awbrey and Bowles 1989.

Fleming, G. G. and E. J. Rickley. 1994. HNM Heliport Noise Model Version 2.2 User's Guide Final Report. DOT/VNTSC-FAA-94-3, DOT/FAA/EE-94/01. John A. Volpe National Transportation Systems Center, Cambridge, MA.

Fletcher, J. L. and R. G. Busnel, Eds. 1978. Effects of Noise on Wildlife. Academic Press, New York.

Fraker, M. A. and P. N. Fraker. 1979. The 1979 Whale Monitoring Program Mackenzie Estuary, N. W. T. Rep. LGL Ltd. for Esso Resources Canada Ltd., Sidney, B. C., as cited in Richardson et al. 1991.

Francine, J. K. and A. E. Bowles. 1995. Field measurements of Merriam's kangaroo rat, Dipodomys merriami, hearing on the Barry M. Goldwater Air Force Range using auditory evoked potentials. Inter-noise 95, the 1995 Congress on Noise Control Engineering, Newport Beach, CA.

Francine, J. K., J. S. Yaeger and A. E. Bowles. 1995. Sound from low-altitude jet overflights in burrows of the Merriam's kangaroo rat, Dipodomys merriami, and the kit fox, Vulpes macrotis. Inter-noise 95, the 1995 Congress on Noise Control Engineering, Newport, CA.

Frankel, A. S. and C. W. Clark. 1998. Results of low-frequency playback of M-sequence noise to humpback whales, Megaptera novaeangliae, in Hawaii. Can. J. Zool. 1998:521-535.

Fraser, J. D., L. D. Frenzel and J. E. Mathison. 1985. The impact of human activities on breeding bald eagles in north-central Minnesota. J. Wildl. Manage. 49(3):585-592.

Frost, K. J., L. F. Lowry and G. Carroll. 1993. Beluga whale and spotted seal use of a coastal lagoon system in the northeastern Chukchi Sea. Arctic 46(1):8-16.

Gabrey, S. W. and R. A. Dolbeer. 1996. Rainfall effects on bird-aircraft collisions at two United States airports. Wildl. Soc. Bull. 24(2):272-275. 
Gese, E. M., O. J. Rongstad and W. R. Mytton. 1989. Changes in coyote movements due to military activity. J. Wildl. Manage. 53(2):334-339.

Gladwin, D. N., D. A. Asherin and K. M. Manci. 1988. Effects of Aircraft Noise and Sonic Booms on Fish and Wildlife: Results of a Survey of U. S. Fish and Wildlife Endangered Species and Ecological Services Field Offices, Refuges, Hatcheries, and Research Centers. NERC-88/30. U. S. Fish and Wildlife Service, Fort Collins, CO.

Grubb, T. G. and W. W. Bowerman. 1997. Variations in breeding bald eagle responses to jets, light planes and helicopters. J. Raptor Res. 31(3):213-222.

Grzimek, B. 1990. Grzimek's Encyclopedia of Mammals. McGraw-Hill, New York.

Gunn, A., F. L. Miller, R. Glaholt and K. Jingfors. 1985. Behavioral responses of barren-ground caribou cows and calves to helicopters on the Beverly Herd calving grounds. Proceedings of the North American Caribou Workshop 1:10-14.

Harbers, L. H., D. R. Ames, A. B. Davis and M. B. Ahmed. 1975. Digestive responses of sheep to auditory stimuli. J. Animal Sci. 41(2):654-658.

Harrington, F. H. and A. M. Veitch. 1991. Short-term impacts of low-level jet fighter training on caribou in Labrador. Arctic 44(4):318-327.

Harrington, F. H. and A. M. Veitch. 1992. Calving success of woodland caribou exposed to low-level jet fighter overflights. Arctic 45(3):213-218.

Harrison, R. T. 1978. Quantifying the acoustic dose when determining the effects of noise on wildlife: pp. 267-285. J. L. Fletcher and R. G. Busnel (eds.), Effects of Noise on Wildlife. Academic Press, New York.

Heffner, R. S., and H. E. Heffner. 1985. Hearing in mammals: the least weasel. J. Mammology 66(4):745-755.

Hewitt, R. P. 1985. Reaction of dolphins to a survey vessel: Effects on census data. Fish. Bull. 83(2):187-193.

Jakimchuk, R. D., E. A. DeBock, H. J. Russell and G. R. Semechuk. 1974. A study of the porcupine caribou herd: pp. R. D. Jakimchuk (ed.) The Porcupine Caribou Herd-Canada. Canadian Arctic Gas Study Ltd. and Alaska Gas Study Co., as cited in EPA 1980.

Johnson, B. K., A. A. Ager, S. L. Findholt, M. J. Wisdom, D. B. Marx, J. W. Kern and L. D. Bryant. 1998. Mitigating spatial differences in observation rate of automated telemetry systems. J. Wildl. Manage. 62(3):958-967.

Johnson, B. W. 1977. The Effects of Human Disturbance on a Population of Harbor Seals. 1: pp. 422432. Environ. Assess. Alaskan Cont. Shelf, Annu. Rep. Princ. Invest. NOAA, Boulder, CO, as cited in Richardson et al. 1995.

Jorgensen, E. E., S. Demarais, S. M. Sell and S. P. Lerich. 1998. Modeling habitat suitability for small mammals in Chihuahuan desert foothills of New Mexico. J. Wildl. Manage. 62:989-996.

Kastak, D. and R. J. Schusterman. 1996. Temporary threshold shift in a harbor seal (Phoca vitulina). J. Acoust. Soc. Am. 100(3):1905-1908.

Kelly, B. P., L. T. Quakenbush and J. R. Rose. 1986. Ringed Seal Winter Ecology and Effects of Noise Disturbance. 61: pp. 447-536. Outer Cont. Shelf Environ. Assess. Program, Final Rep. Princ. Invest. OCS Study MMS 89-0026, Anchorage, AK, as cited in Richardson et al. 1995.

King, M. J. and S. L. Buchmann. 1995. Bumble bee-initiated vibration release mechanism of rhododendron pollen. Amer. J. Bot. 82(11):1407-1411.

Koski, W. R., G. W. Miller and R. A. Davis. 1988. The Potential Effects of Tanker Traffic on the Bowhead Whale in the Beaufort Sea. LGL Ltd. for Dep. Indian Affairs \& Northern Dev., King City, Ontario, Canada, as cited in Richardson et al. 1995. 
Krausman, P. R. and J. J. Hervert. 1983. Mountain sheep responses to aerial surveys. Wildl. Soc. Bull. 11(4):1983.

Krausman, P. R., B. D. Leopold and D. L. Scarbrough. 1986. Desert mule deer response to aircraft. Wildl. Soc. Bull. 14:68-70.

Krausman, P. R., M. C. Wallace, C. L. Hayes and D. W. de Young. 1998. Effects of jet aircraft on mountain sheep. J. Wildl. Manage. 62(4):1246-1254.

Kushlan, J. A. 1979. Effects of helicopter censuses on wading bird colonies. J. Wildl. Manage. 43(3):756-760.

Leatherwood, S., F. T. Awbrey and J. A. Thomas. 1982. Minke whale response to a transiting survey vessel. Rep. Int. Whal. Commn. 32:795-802.

LeBlanc, M. M., C. Lombard, R. Massey, E. Klapstein and S. Lieb. 1991. Behavioral and Physiological Responses of Horses to Simulated Aircraft Noise. AL-TR-1991-0123. University of Florida at Gainesville for Armstrong Laboratory, Wright-Patterson Air Force Base, Ohio, Gainesville, FL.

Linnell, M. A., M. R. Conover and T. J. Ohashi. 1996. Analysis of bird strikes at a tropical airport. J. Wildl. Manage. 60(4):935-945.

Linnell, M. A. 1999. Biases in bird strike statistics based on pilot reports. J. Wildl. Manage. 63(3):9971003.

Ljungblad, D. K. 1981. Aerial Surveys of Endangered Whales in the Beaufort Sea, Chukchi Sea, and Northern Bering Sea. NOSC TD 449. Naval Ocean Systems Center, San Diego, CA, as cited in Richardson et al. 1985a.

Ljungblad, D. K. 1986. Endangered whale aerial surveys in the Navarin Basin and St. Matthew Hall planning areas, Alaska: pp. Appendix E. D. K. Ljungblad, et al. (ed.) Aerial Surveys of Endangered Whales in the Northern Bering, Eastern Chukchi, and Alaskan Beaufort Seas, 1985: With a Seven Year Review, 1979-1985. NOSC TR 1111. U. S. Naval Ocean Systems Center, San Diego, CA, as cited in Richardson et al. 1995.

Lucas, M. J. and R. A. Lee. 1995. Noise Calculation Procedures Contained in the MOA Range Noisemap (MR NMAP) Computer Program. AL/OE-TR-1995-0147. Air Force Materiel Command, WrightPatterson AFB, Brooks Air Force Base, TX.

Luz, G. A. and J. B. Smith. 1976. Reactions of pronghorn antelope to helicopter flight. J. Accoust. Soc. Am. 59(6):1514-1515.

Lyles, L. 1975. Possible effects of wind erosion on soil productivity. J. Soil and Water Conservation 30:279-283.

Maier, J. A. K., S. M. Murphy, R. G. White and M. D. Smith. 1998. Responses of caribou to overflights by low-altitude jet aircraft. J. Wildl. Manage. 62(2):752-766.

Malme, C. I., P. R. Miles, C. W. Clark, P. Tyack and J. E. Bird. 1984. Investigations of the Potential Effects of Underwater Noise from Petroleum Industry Activities on Migrating Gray Whale Behavior. Phase 2: January 1984 Migration. MMS/AK-ESU-84-025. U.S. Department of the Interior, Minerals management Service, Alaska OCS Office, Anchorage, AK.

Manci, K. M., D. N. Gladwin, R. Villella and M. G. Cavendish. 1988. Effects of Aircraft Noise and Sonic Booms on Domestic Animals and Wildlife: a Literature Synthesis. NERC-88/29. U.S. Fish and Wildlife Service National Ecology Research Center, Ft. Collins, CO.

McClenaghan, L. and A. E. Bowles. 1995. Effects of low -altitude overflights on populations of small mammals on the Barry M. Goldwater Range. Inter-noise 95, the 1995 Congress on Noise Control Engineering, Newport, CA.

Merzenich, m. M., L. Kitzes and L. Aitkin. 1973. Anatomical and physiological evidence for auditory specialization in the mountain beaver (Aplodontia rufa). Brain Res. 58:331-344. 
Miller, F. L. and A. Gunn. 1979. Responses of Peary Caribou and Muskoxen to Turbo-Helicopter Harassment, Prince of Wales Island, Northwest Territories, 1976-77. Occasional Paper Number 40. Canadian Wildlife Service, Edmonton.

Miller, M. W., K. C. Jensen, W. E. Grant and M. W. Weller. 1994. A simulation model of helicopter disturbance of molting Pacific black brant. Ecolog. Modelling 73:293-309.

Molino, J. A. 1982. Should Helicopter Noise Be Measured Differently From Other Aircraft Noise? - A Review of the Psycholacoustic Literature. Contractor report no. 3609. NASA for Langley Research Center .

Mosbech, A. and C. Glahder. 1991. Assessment of the impact of helicopter disturbance on moulting pinkfooted geese Anser brachyrhynchus and barnacle geese Branta leucopsis in Jameson Land, Greenland. Ardea 79:233-238.

Navy (U. S. Navy). 1998. Final Environmental Impact Statement for the Realignment of E-2 Squadrons from Marine Corps Air Station (MCAS) Miramar, Vol. I. U. S. Department of Defense, San Diego, CA.

Niklas, K. J. 1998. Effects of vibration on mechanical properties and biomass allocation pattern of Capsella bursa-pastoris (Cruciferae). Annals of Botany 82:147-156.

Osborn, L. S. 1985. Population Dynamics, Behavior, and the Effect of Disturbance on Haulout Patterns of the Harbor Seal Phoca vitulina richardsi. Elkhorn Slough, Monterey Bay, California. Environmental Studies and Biology. Santa Cruz, CA, University of California at Santa Cruz 75 pp., as cited in Richardson et al. 1995.

Ovsyanikov, N. G., L. L. Bove and A. A. Kochnev. 1994. [The factors causing mass death of walruses on coastal rookeries] (in Russian, English summ.). Zool. Zh. 73(5):80-87, as cited in Richardson et al. 1995.

Owens, N. W. 1977. Responses of wintering Brent Geese to human disturbance. Wildfowl 28:5-14.

Painterkurt, S. and S. S. Schneider. 1998b. Age and behavior of honey-bees, Apis mellifera (Hymenoptera, Apidae) that perform vibration signals on workers. Ethology 104(6):457-473.

Painterkurt, S. and S. S. Schneider. 1998a. Age and behavior of honey-bees, Apis mellifera (Hymenoptera, Apidae), that perform vibration signals on queens and queen cells. Ethology 104(6):475-485.

Pater, L. D., D. K. Delaney, T. J. Hayden, B. Lohr, and R. Dooling. 1999. Assessment of Training Noise Impacts on the Red-cockaded Woodpecker: Preliminary Results. CERL Technical Report 99/51. U. S. Army Corps of Engineers Construction Engineering Research Laboratory.

Peterson, A. 1986. Habitat Suitability Index Models: Bald Eagle (Breeding Season). Biological Report 82(10.126). Fish and Wildlife Service, U. S. Dept. of the Interior.

Peterson, A. P. G. and L. L. Beranek. 1956. Handbook of Noise Measurement. General Radio Company, Cambridge, MA.

Platt, J. B. 1977. The Breeding Behavior of Wild and Captive Gyrfalcons in Relation to their Environment and Human Disturbance. Ithaca, NY, Cornell University, as cited in Awbrey and Bowles 1989.

Rand, G. M. and J. R. Newman. 1998. The applicability of habitat evaluation methodologies in ecological risk assessment. Hum. Ecol. Risk Assess. 4(4):905-929.

Rathbun, G. B. 1988. Fixed-wing airplane versus helicopter surveys of manatees (Trichechus manatus). Mar. Mamm. Sci. 4(1):71-75.

Richardson, C. T. and C. K. Miller. 1997. Recommendations for protecting raptors from human disturbance: a review. Wildl. Soc. Bull. 25(3):634-638. 
Richardson, W. J., M. A. Fraker, B. Wursig and R. S. Wells. 1985a. Behaviour of bowhead whales Balaena mysticetus summering in the Beaufort Sea: Reactions to industrial activities. Biolog. Conserv. 32:195-230.

Richardson, W. J., C. R. Greene Jr., C. I. Malme and D. H. Thomson. 1991. Effects of Noise on Marine Mammals. MMS 90-0093. U.S. Department of the Interior, Minerals Management Service, Atlantic OCS Region, Herndon, VA.

Richardson, W. J., C. R. Greene Jr., C. I. Malme and D. H. Thomson. 1995. Marine Mammals and Noise. Academic Press, San Diego, CA.

Richardson, W. J., R. S. Wells and B. Wursig. 1985b. Disturbance responses of bowheads, 1980-1984: pp. 89-196. W. J. Richardson (ed.) Behavior, disturbance responses and distribution of bowhead whales Balaena mysticetus in the eastern Beaufort Sea, 1980-1984. OCS Study MMS 85-0034. LGL Ecol. Res. Assoc., Inc. for U.S. Minerals Manage. Serv., Bryan, TX, as cited in Richardson et al. 1991.

Richardson, W. J. and B. Wursig. 1997. Influences of man-made noise and other human actions on cetacean behaviour. Mar. Fresh. Behav. Physiol. 29:183-209.

Russell, K. R., and S. A. Gauthreaux, Jr. 1998. Use of weather radar to characterize movements of roosting purple martins. Wildl. Soc. Bull. 26:5-16.

Salter, R. E. 1979. Site utilization, activity budgets, and disturbance responses of Atlantic walruses during terrestrial haul-out. Can. J. Zool. 57(6):1169-1180.

Sandeman, D. C., J. Tautz and M. Lindauer. 1996. Transmission of vibration across honeycombs and its detection by bee leg receptors. J. Exper. Biol. 199(12):2585-2594.

Seegar, W. S., P. N. Cutchis, M. R. Fuller, J. J. Suter, V. Bhatnagar and J. G. Wall. 1996. Fifteen years of satellite tracking development and application to wildlife research and conservation. Johns Hopkins APL Technical Digest 17(4):401-411.

Seegar, W. S., M. R. Fuller and C. f. C. R. Technology. 1996/1997. Legacy Demonstration of Technologies and Methodologies Relevant to Military Natural Resources Conservation. U. S. Army Edgewood Research, Development and Engineering Center; Department of Interior Raptor Research and Technical Assistance Center; Center for Conservation Research \& Technology, University of Maryland Baltimore County, Aberdeen Proving Ground, MD; Boise, ID; Baltimore, MD.

Sekyra, C. A., W. C. Storey and R. Yates. 1975. Validity of aircraft noise data. J. Acoust. Soc. Am. $58(1)$.

Sergeant, D. E. and W. Hoek. 1988. An update on the status of white whales Delphinapterus leucas in the Saint Lawrence Estuary, Canada. Biol. Conserv. 45(4):287-302.

Shannon, H. D., W. S. Seegar, G. S. Young, C. J. Pennycuick, M. R. Fuller, M. A. Yates, B. J. Dayton, M. B. Henke, M. A. Bramer, T. Maechtle and L. Schueck. 1999 draft. Bird flight forecast and information system.

Shotton, L. R. 1982. Response of Wildlife and Farm Animals to Low-Level Military Jet Overflight. The Reporter. 11(6):161-4.

Snyder, N. F. R., H. W. Kale and P. W. Sykes, Jr. ca. 1978, unpublished. An Evaluation of Some Potential Impacts of the Proposed Dade County Training Jetport on the Endangered Everglade Kite.

Solman, V. E. F. 1981. Birds and aviation. Environ. Conserv. 8:45-51.

Sprouse, W. L. and A. B. Anderson. 1996. Land Condition - Trend Analysis Data Dictionary. Center for Ecological Management of Military Lands, Colorado State University, Fort Collins, CO. 
SRA. 1988. Results of the 1986-1987 Gray Whale Migration and landing Craft, Air Cushion Study Program. U. S. Navy Contr. N62474-86-M-0942. Southwest Res. Assoc. for U. S. Nav. Ocean Facil. Eng. Comm., San Bruno, CA.

Stalmaster, M. V. and J. L. Kaiser. 1997. Flushing responses of wintering bald eagles to military activity. J. Wildl. Manage. 61:1307-1313.

Stockwell, C. A., G. C. Bateman and J. Berger. 1991. Conflicts in national parks: a case study of helicopters and bighorn sheep time budgets at the Grand Canyon. Biolog. Conserv. 56:317-328.

Suter, G. W., II. 1999. A framework for assessment of ecological risks from multiple activities. Human and Ecological Risk Assessment 5:397-413.

Suter, G. W., II, R. A. Efroymson, B. E. Sample and D. S. Jones. 2000. Ecological Risk Assessment for Contaminated Sites. Lewis Publishers, Boca Raton, FL.

Suter, G. W., II, K. A. Reinbold, W. Hodge, and M. K. Chawla. 1998 draft. A Framework for Assessment of Risks of Military Training and Testing to Natural Resources. Oak Ridge National Laboratory, Oak Ridge, TN, ORNL/TM-13610.

Teske, M. E., A. J. Bilanin and J. W. Barry. 1993. Decay of aircraft vortices near the ground. AIAA J. 31(8):1531-1533.

Teske, M. E., A. E. Kaufman, C. W. George and G. M. Johnson. 1997. Field measurements of helicopter rotor wash in hover and forward flight. J. Aircraft 34(6):813-814.

Thompson, M. M. 1999. Using a GIS to integrate seasonal raptor distributions into a bird avoidance model for aircraft. J. Raptor Res. 33(1):53-58.

Trimper, P. G., N. M. Standen, L. M. Lye, D. Lemons, T. E. Chubbs and G. W. Humphries. 1998. Effects of low-level jet aircraft noise on the behaviour of nesting osprey. J. Appl. Ecol. 35:122130.

Turgeon, R. and J. A. Webb. 1971. Growth inhibition by mechanical stress. Science 174:961-962.

Urick, R. J. 1972. Noise signature of an aircraft in level flight over a hydrophone in the sea. J. Acoust. Soc. Am. 52(993-999).

USACHPPM (U. S. Army Center for Health Promotion and Preventative Medicine). 1998. Environmental Noise Management: An Orientation Handbook for Army Facilities. Principal authors: G. A. Luz and W. A. Russell, Jr.

USAF (Department of the Air Force). 1994. Air Force Instruction 32-7064. Integrated Natural Resources Management.

USAF (Department of the Air Force). 1995. Final Environmental Impact Statement. Alaska Military Operations Areas. Department of the Air Force, Elmendorf Air Force Base, Alaska.

USAF (Department of the Air Force). 1998. Enhanced Training in Idaho. Environmental Impact Statement. U. S. Air Force, Mountain Home Air Force Base, ID.

USFWS (U. S. Fish and Wildlife Service). 1980. Habitat Evaluation Procedures. ESM 102. Division of Ecological Sciences, U. S. Fish and Wildlife Service, Department of the Interior, Washington, D. C.

Valkenburg, P. and J. L. Davis. 1985. The reaction of caribou to aircraft: a comparison of two herds. Proceedings of the North American Caribou Workshop 1:7-9.

Ward, D. H., R. A. Stehn, W. P. Erickson and D. V. Derksen. 1999. Response of fall-staging brant and Canada geese to aircraft overflights in southwestern Alaska. J. Wildl. Manage. 63:373-381.

Watson, J. W. 1993. Responses of nesting bald eagles to helicopter surveys. Wildl. Soc. Bull. 21:171178.

Weber, T. P., T. Alerstam and A. Hedenstrom. 1998. Stopover decisions under wind influence. J. Avian Biol. 29:552-560. 
Weisenberger, M. E., P. R. Krausman, M. C. Wallace, D. W. de Young and O. E. Maughan. 1996. Effects of simulated jet aircraft noise on heart rate and behavior of desert ungulates. J. Wildl. Manage. 60(1):52-61.

Wever, E. G. and E. A. Peterson. 1963. Auditory sensitivity in three iguanid lizards. J. Auditory Res. 3:205-212.

Wever, E. G. and J. A. Vernon. 1960. The problem of hearing in snakes. J. Auditory Res. 1:77-83.

White, R. G. 1983. Foraging patterns and their multiplier effects on productivity of northern ungulates. Oikos 40:377-384.

Windsor, J. 1977. The Response of Peregrine Falcons (Falco peregrinus) to Aircraft and Human Disturbance. Canadian Wildlife Service Mackenzie Valley Pipeline Investigations, Government of Canada, Ottawa, as cited in Awbrey and Bowles 1989.

Woodruff, N. P. and F. H. Siddoway. 1965. A wind erosion equation. Soil Sci. Soc. Am. Proc. 29:602608.

Würsig, B., S. K. Lynn, T. A. Jefferson, and K. D. Mullin. 1998. Behaviour of cetaceans in the northern Gulf of Mexico relative to survey ships and aircraft. Aquatic Mammals 24.1:41-50. 
108

APPENDIX A 


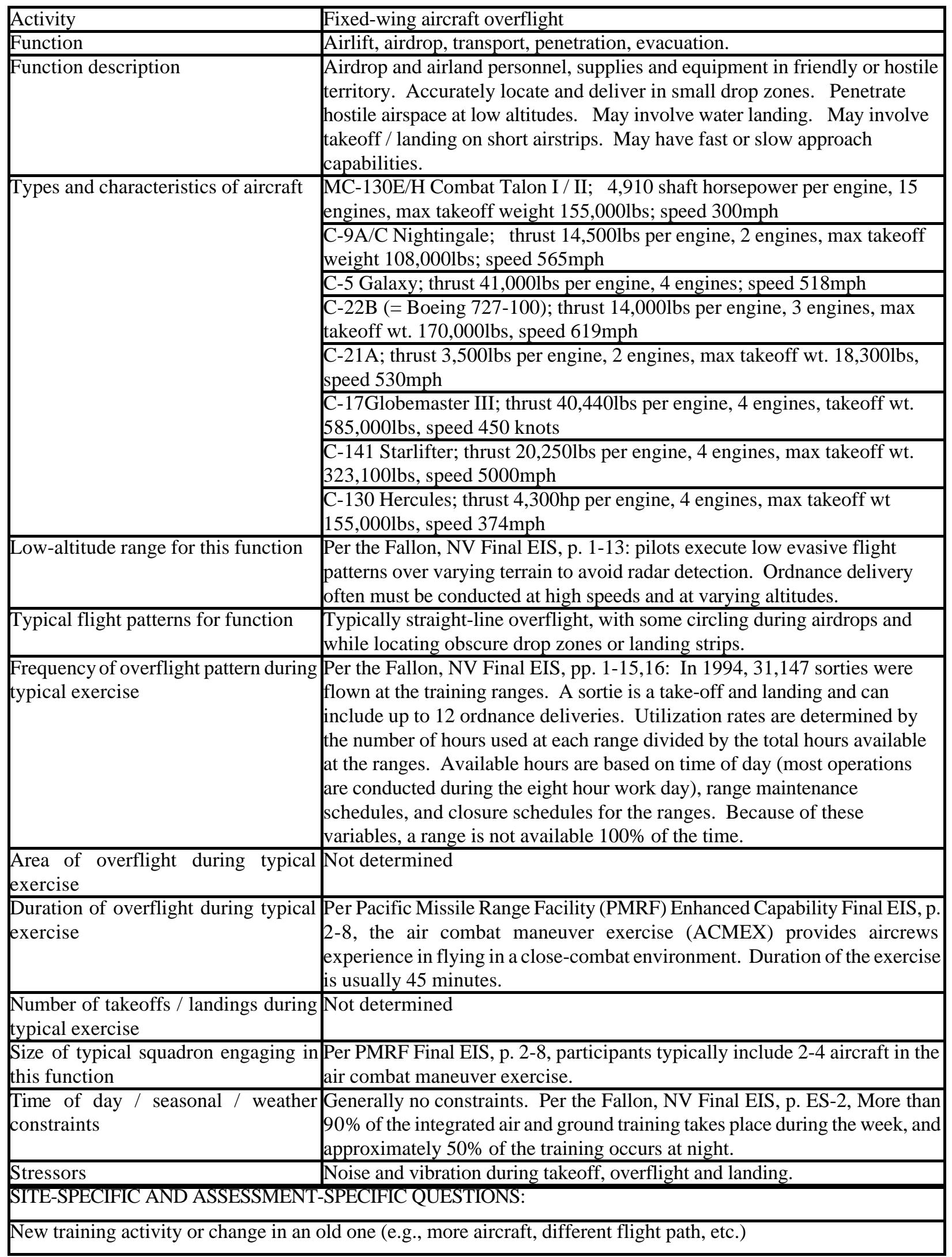


Any training/testing activities occur at same time as overflights? (Do these produce loud sound?)

Which training activities occur on land below/near overflight routes?

\begin{tabular}{|c|c|}
\hline Activity & Fixed-wing aircraft overflight \\
\hline Function & Platform \\
\hline Function description & $\begin{array}{l}\text { Aircraft serves as a flying platform for one or more of the following: } \\
\text { command and control, communications center, airborne warning system, } \\
\text { surveillance to locate, classify and track ground and air targets. }\end{array}$ \\
\hline Types and characteristics of aircraft & E-8C Joint Stars; 4 engine, max takeoff wt. 336,000, speed 0.84 mach \\
\hline & E-4B; thrust 52,500lbs per engine, 4 engines, max takeoff wt. $800,000 \mathrm{lbs}$ \\
\hline & $\begin{array}{l}\text { E-3 Sentry AWACS; thrust 21,000lbs per engine, } 4 \text { engines, max takeoff } \\
\text { wt. 347,000lbs, optimum speed } 360 \mathrm{mph}\end{array}$ \\
\hline Low-altitude range for this function & $\begin{array}{l}\text { Per p. 2-3 the Final EIS for the Realignment of E-2 Squadrons from Marine } \\
\text { Corps Air Station (MCAS) Miramar, the home base field elevation must be } \\
\text { less than 1,000 ft MSL to adequately replicate aircraft flight characteristics } \\
\text { experienced at sea level when operating from aircraft carriers. }\end{array}$ \\
\hline Typical flight patterns for this function & wide circling (searching diameter of circles) \\
\hline $\begin{array}{l}\text { Frequency of overflight pattern during } \\
\text { typical exercise }\end{array}$ & Not determined. \\
\hline $\begin{array}{l}\text { Area of overflight during typical } \\
\text { exercise }\end{array}$ & $\begin{array}{l}\text { Although not specifically listed, on p. 1-3 of the Final EIS for the } \\
\text { Realignment of E-2 Squadrons from Marine Corps Air Station (MCAS) } \\
\text { Miramar, the E-2 aircraft use regular FAA flight tracks and would not use } \\
\text { military training routes (MTRs). }\end{array}$ \\
\hline $\begin{array}{l}\text { Duration of overflight during typical } \\
\text { exercise }\end{array}$ & $\begin{array}{l}\text { Although not specifically listed, on p. ES-5 of the Final EIS for the } \\
\text { Realignment of E-2 Squadrons from Marine Corps Air Station (MCAS) } \\
\text { Miramar, typically one squadron (I.e., } 4 \text { aircraft) is away from the home } \\
\text { base for a period of 14-15 months every two years. Over this period, each } \\
\text { squadron spends approximately six months deployed to the Western } \\
\text { Pacific; two months deployed to Panama doing counter-drug operations; } \\
\text { and approximately seven months aways from home base involved in air } \\
\text { wing/battle group training. }\end{array}$ \\
\hline $\begin{array}{l}\text { Number of takeoffs / landings during } \\
\text { typical exercise }\end{array}$ & $\begin{array}{l}\text { Per pp. ES-4,5 of the Final EIS for the Realignment of E-2 Squadrons from } \\
\text { Marine Corps Air Station (MCAS) Miramar, one E-2 squadron consists of } \\
\text { four aircraft. (E-2 Hawkeyes are similar to the other types of aircraft } \\
\text { listed above.) Annual E-2 aircraft operations in this EIS include: 1,009 } \\
\text { annual take-offs and landings (sorties), } 4,960 \text { field carrier landing practice } \\
\text { (FCLP) cycles, 3,404 automated carrier landing system (ACLS) cycles, } \\
851 \text { "touch and go" cycles, and } 160 \text { ground controlled approach (GCA) } \\
\text { cycles. }\end{array}$ \\
\hline $\begin{array}{l}\text { Size of typical squadron engaging in } \\
\text { this function }\end{array}$ & 1 or 2 aircraft \\
\hline $\begin{array}{l}\text { Time of day / seasonal / weather } \\
\text { constraints }\end{array}$ & $\begin{array}{l}\text { Sixty-six percent of the FCLPs/ACLSs are conducted during } \\
\text { evening/nighttime hours to simulate nighttime aircraft carrier landings. }\end{array}$ \\
\hline Stressors & Noise and vibration \\
\hline \multicolumn{2}{|c|}{ SITE-SPECIFIC AND ASSESSMENT-SPECIFIC QUESTIONS: } \\
\hline \multicolumn{2}{|c|}{ New training activity or change in an old one (e.g., more aircraft, different flight path, etc.) } \\
\hline \multicolumn{2}{|c|}{ Any training/testing activities occur at same time as overflights? (Do these produce loud sound?) } \\
\hline \multicolumn{2}{|c|}{ Which training activities occur on land below/near overflight routes? } \\
\hline Activity & Fixed-wing aircraft overflight \\
\hline Function & $\begin{array}{l}\text { Close air support, air inderdiction, armed reconnaissance, and combat } \\
\text { search and rescue. }\end{array}$ \\
\hline
\end{tabular}




\begin{tabular}{|c|c|}
\hline Function description & $\begin{array}{l}\text { Close air support of ground forces, air inderdiction, and armed } \\
\text { reconnaissance. Also drop \& extraction zone support and combat search } \\
\text { and rescue. May involve wide combat radius and short takeoff \& landing }\end{array}$ \\
\hline \multirow[t]{2}{*}{ Types and characteristics of aircraft } & $\begin{array}{l}\text { AC-130H Spectre: } 4910 \text { horsepower/engine, } 4 \text { engines, maximum takeoff } \\
\text { weight } 155,000 \mathrm{lbs} \text {, speed } 300 \mathrm{mph}\end{array}$ \\
\hline & $\begin{array}{l}\text { A-10/OA-10 Thunderbolt II: } 9,065 \mathrm{lbs} / \text { engine, } 2 \text { engines, maximum } \\
\text { takeoff weight } 51,000 \mathrm{lbs} \text {, speed } 420 \mathrm{mph}\end{array}$ \\
\hline Low-altitude range for this function & $\begin{array}{l}\text { The Thunderbolt aircraft can loiter near battle areas for extended periods } \\
\text { and operate under } 1,000 \mathrm{ft} \text { ceilings. }\end{array}$ \\
\hline Typical flight patterns for this function & $\begin{array}{l}\text { The reconnaissance, close air support, and combat search \& rescue } \\
\text { missions may involve a back and forth flight path, whereas drop \& } \\
\text { extraction zone support may involve a straight line flight path. }\end{array}$ \\
\hline $\begin{array}{l}\text { Frequency of overflight pattern during } \\
\text { typical exercise }\end{array}$ & Not determined. \\
\hline $\begin{array}{l}\text { Area of overflight during typical } \\
\text { exercise }\end{array}$ & Not determined. \\
\hline $\begin{array}{l}\text { Duration of overflight during typical } \\
\text { exercise }\end{array}$ & Not determined. \\
\hline $\begin{array}{l}\text { Number of takeoffs / landings during } \\
\text { typical exercise }\end{array}$ & Not determined. \\
\hline $\begin{array}{l}\text { Size of typical squadron engaging in } \\
\text { this function }\end{array}$ & Not determined. \\
\hline $\begin{array}{l}\text { Time of day / seasonal / weather } \\
\text { constraints }\end{array}$ & Generally no constraints. \\
\hline Stressors & Noise and vibration during takeoff, overflight and landing. \\
\hline \multicolumn{2}{|c|}{ SITE-SPECIFIC AND ASSESSMENT-SPECIFIC QUESTIONS: } \\
\hline \multicolumn{2}{|c|}{ New training activity or change in an old one (e.g., more aircraft, different flight path, etc.) } \\
\hline \multicolumn{2}{|c|}{ Any training/testing activities occur at same time as overflights? (Do these produce loud sound?) } \\
\hline \multicolumn{2}{|c|}{ Which training activities occur on land below/near overflight routes? } \\
\hline Activity & Fixed-wing aircraft overflight \\
\hline Function & Multi-role heavy bomber \\
\hline Function description & $\begin{array}{l}\text { B-2 Spirit capable of delivering both conventional and nuclear munitions. } \\
\text { B-1B Lancer can deliver conventional weapons and has a swing-wing design } \\
\text { allowing short takeoff roll and fast base escape profile. }\end{array}$ \\
\hline \multirow[t]{2}{*}{ Types and characteristics of aircraft } & $\begin{array}{l}\text { B-2 Spirit: 17,300 lbs/engine, } 4 \text { engines, typical takeoff weight } 336,500 \\
\text { lbs, speed--high subsonic. }\end{array}$ \\
\hline & $\begin{array}{l}\text { B-1B Lancer: } 30,000+\mathrm{lbs} \text { with afterburner/engine, } 4 \text { engines, maximum } \\
\text { takeoff weight } 477,000 \mathrm{lbs}, 900+\mathrm{mph} \text {. }\end{array}$ \\
\hline Low-altitude range for this function & $\begin{array}{l}\text { Nap of the earth aircraft. B-1B Lancer has a short takeoff roll due to its } \\
\text { swing-wing design. }\end{array}$ \\
\hline $\begin{array}{l}\text { Typical flight patterns for this } \\
\text { function }\end{array}$ & $\begin{array}{l}\text { Assume that since these are bomber aircraft, the flight path would generally } \\
\text { be a straight line. }\end{array}$ \\
\hline $\begin{array}{l}\text { Frequency of overflight pattern } \\
\text { during typical exercise }\end{array}$ & Specific to aircraft and exercise. \\
\hline $\begin{array}{l}\text { Area of overflight during typical } \\
\text { exercise }\end{array}$ & $\begin{array}{l}\text { Assume that since these bomber aircraft have an unrefueled intercontinental } \\
\text { range, the area of overflight would be extremely large. }\end{array}$ \\
\hline $\begin{array}{l}\text { Duration of overflight during typical } \\
\text { exercise }\end{array}$ & Not determined. \\
\hline $\begin{array}{l}\text { Number of takeoffs / landings during } \\
\text { typical exercise }\end{array}$ & Not determined. \\
\hline Size of typical squadron engaging in & Not d \\
\hline
\end{tabular}




\begin{tabular}{|c|c|}
\hline this function & \\
\hline $\begin{array}{l}\text { Time of day / seasonal / weather } \\
\text { constraints }\end{array}$ & Not determined. \\
\hline Stressors & Noise and vibration during takeoff, overflight and landing. \\
\hline SITE-SPECIFIC AND ASSESSMENT & -SPECIFIC QUESTIONS: \\
\hline New training activity or change in an & old one (e.g., more aircraft, different flight path, etc.) \\
\hline Any training/testing activities occur a & t same time as overflights? (Do these produce loud sound?) \\
\hline Which training activities occur on lan & d below/near overflight routes? \\
\hline Activity & Fixed-wing aircraft overflight \\
\hline Function & Aerial refueling (tanker). \\
\hline Function description & $\begin{array}{l}\text { Air refueling can be used to enhance airpower flexibility and } \\
\text { responsiveness during deployment and employment by improving the range } \\
\text { of tactical aircraft. Air refueling acts as a force multiplier and facilitates } \\
\text { extended airborne operations. KC-135 Stratotanker can also fly command } \\
\text { post missions and reconnaissance. KC-10A Extender can combine tasks of } \\
\text { tanker and cargo (personnel and equipment) aircraft. MC-130P Combat } \\
\text { Shadow flies clandestine or low visibility, low-level missions providing air } \\
\text { refueling for special operations helicopters. Secondary mission } \\
\text { capabilities include airdrops of small special operations teams and bundles. }\end{array}$ \\
\hline Types and characteristics of aircraft & $\begin{array}{l}\text { KC-135 Stratotanker (modified Boeing 707): Model "R": 21,634 } \\
\text { lbs/engine, Model "E": 18,000 lbs/engine, } 4 \text { engines, maximum takeoff } \\
\text { weight } 322,500 \mathrm{lbs}, 530 \mathrm{mph} .\end{array}$ \\
\hline & $\begin{array}{l}\text { KC-10A Extender (modified DC-10): } 52,500 \mathrm{lbs} / \mathrm{engine}, 3 \text { engines, } \\
\text { maximum takeoff weight 590,000 lbs, } 619 \mathrm{mph} \text {. }\end{array}$ \\
\hline & $\begin{array}{l}\text { MC-130P Combat Shadow: 4,910 horsepower/engine, } 4 \text { engines, max } \\
\text { takeoff weight } 155,000 \mathrm{lbs} \text {, speed } 289 \mathrm{mph} \text { at sea level. }\end{array}$ \\
\hline Low-altitude range for this function & $\begin{array}{l}\text { Work in progress. Although it did mention that the MC-130P Combat } \\
\text { Shadow conducts low-level refueling operations. }\end{array}$ \\
\hline $\begin{array}{l}\text { Typical flight patterns for this } \\
\text { function }\end{array}$ & $\begin{array}{l}\text { Assume that the flight path is generally in a straight line for refueling } \\
\text { operations, but could be back and forth for reconnaissance missions. }\end{array}$ \\
\hline $\begin{array}{l}\text { Frequency of overflight pattern } \\
\text { during typical exercise }\end{array}$ & Not determined. \\
\hline $\begin{array}{l}\text { Area of overflight during typical } \\
\text { exercise }\end{array}$ & Not determined. \\
\hline $\begin{array}{l}\text { Duration of overflight during typical } \\
\text { exercise }\end{array}$ & Not determined. \\
\hline $\begin{array}{l}\text { Number of takeoffs / landings during } \\
\text { typical exercise }\end{array}$ & Not determined. \\
\hline $\begin{array}{l}\text { Size of typical squadron engaging in } \\
\text { this function }\end{array}$ & Not determined. \\
\hline $\begin{array}{l}\text { Time of day / seasonal / weather } \\
\text { constraints }\end{array}$ & $\begin{array}{l}\text { None listed. Specifically listed that KC-10A Extender is equipped with } \\
\text { special lighting for night operations and the MC-130P Combat Shadow } \\
\text { conducts night-vision goggle takeoffs and landings.. }\end{array}$ \\
\hline Stressors & Noise and vibration during takeoff, overflight and landing. \\
\hline SITE-SPECIFIC AND ASSESSMENT & -SPECIFIC QUESTIONS: \\
\hline New training activity or change in a & old one (e.g., more aircraft, different flight path, etc.) \\
\hline Any training/testing activities occur & t same time as overflights? (Do these produce loud sound?) \\
\hline Uit 10 & below/nea \\
\hline Activity & t overflight \\
\hline
\end{tabular}




\begin{tabular}{|c|c|}
\hline Function & $\begin{array}{l}\text { Multi-purpose: Air interdiction, offensive counter-air, and maritime } \\
\text { operations, including ocean surveillance. }\end{array}$ \\
\hline Function description & $\begin{array}{l}\text { Long-range, multi-purpose bomber used for air interdiction, offensive } \\
\text { counter-air, and maritime operations. Can carry nuclear or conventional } \\
\text { weapons. During Desert Storm, B-52s delivered } 40 \% \text { of all weapons } \\
\text { dropped by coalition forces. Can assist the Navy in anti-ship and mine- } \\
\text { laying operations. In } 2 \text { hours, two B-52s can monitor } 140,000 \text { square } \\
\text { miles of ocean surface. }\end{array}$ \\
\hline Types and characteristics of aircraft & $\begin{array}{l}\text { B-52 Stratofortress: } 17,000 \mathrm{lbs} / \text { engine, } 8 \text { engines, max takeoff weight } \\
488,000 \mathrm{lbs} \text {, speed } 650 \mathrm{mph}\end{array}$ \\
\hline Low-altitude range for this function & $\begin{array}{l}\text { Per p. 2-3 of the Alaska Military Operations Areas EIS, in order to conduct } \\
\text { realistic and effective major flying exercise (MFE) training, military } \\
\text { operations area (MOA) airspace should extend vertically from as low as } \\
100 \mathrm{ft} \text { AGL to } 17,999 \mathrm{ft} \text { MSL. }\end{array}$ \\
\hline $\begin{array}{l}\text { Typical flight patterns for this } \\
\text { function }\end{array}$ & $\begin{array}{l}\text { Likely to depend on the mission. For bombing missions, the flight path } \\
\text { may be straight; whereas during surveillance, the flight path would be more } \\
\text { back \& forth. }\end{array}$ \\
\hline $\begin{array}{l}\text { Frequency of overflight pattern } \\
\text { during typical exercise }\end{array}$ & $\begin{array}{l}\text { Per pp. 2-4, 2-5, a sortie is defined as a take-off, training flight, and full- } \\
\text { stop landing. Major flying exercise (MFE) training may involve as many as } \\
100 \text { aircraft per day, each flying as many as } 2 \text { sorties per day, for a total of } \\
200 \text { MFE sorties per day. }\end{array}$ \\
\hline $\begin{array}{l}\text { Area of overflight during typical } \\
\text { exercise }\end{array}$ & $\begin{array}{l}\text { Not determined. Although if the aircraft is conducting ocean surveillance, } \\
\text { two B-52 s can monitor } 140,000 \text { square miles in } 2 \text { hours. }\end{array}$ \\
\hline $\begin{array}{l}\text { Duration of overflight during typical } \\
\text { exercise }\end{array}$ & $\begin{array}{l}\text { Per p. 2-4 of the Alaska Military Operations Areas EIS, major flying } \\
\text { exercise (MFE) training would occur no more than } 60 \text { days per year (up to } \\
6 \text { exercises per year). Typically, one exercise would take place some time } \\
\text { between February and April, four exercises between May and August, and } \\
\text { one more exercise between October and November. Generally, an MFE } \\
\text { would run for } 10 \text { flying days, but could last for as many as } 15 \text { flying days. } \\
\text { MFEs normally occur Monday through Friday, } 8: 00 \text { am to } 6: 00 \text { pm. In } \\
\text { general, exercise operations would take place for } 2 \text { hours before noon and } \\
2 \text { hours after noon each exercise day. According to another EIS, if the } \\
\text { aircraft is conducting ocean surveillance, two B-52s can monitor } 140,000 \\
\text { square miles in } 2 \text { hours. }\end{array}$ \\
\hline $\begin{array}{l}\text { Number of takeoffs / landings during } \\
\text { typical exercise }\end{array}$ & $\begin{array}{l}\text { Per p. 2-4 of the Alaska Military Operations Areas EIS, exercise training } \\
\text { includes MFEs, Low-Altitude Navigation and Targeting Infrared for Night } \\
\text { (LANTIRN) exercises, weapons training deployments, Air National Guard } \\
\text { and Air Force Reserve deployments, and multinational exercises. } \\
\text { Exercises integrate air-to-air and air-to-ground missions as well as support } \\
\text { missions such as airborne command and control, electronic combat, } \\
\text { tactical airlift, and search and rescue. During an exercise, aircraft typically } \\
\text { accomplish two sorties per day. }\end{array}$ \\
\hline $\begin{array}{l}\text { Size of typical squadron engaging in } \\
\text { this function }\end{array}$ & Not determined. \\
\hline $\begin{array}{l}\text { Time of day / seasonal / weather } \\
\text { constraints }\end{array}$ & $\begin{array}{l}\text { No constraints listed. Pilots wear night vision goggles (NVGs) to enhance } \\
\text { their night visual, low-level terrain-following operations. }\end{array}$ \\
\hline Stressors & Noise and vibration during takeoff, overflight, and landing. \\
\hline \multicolumn{2}{|c|}{ SITE-SPECIFIC AND ASSESSMENT-SPECIFIC QUESTIONS: } \\
\hline \multicolumn{2}{|c|}{ New training activity or change in an old one (e.g., more aircraft, different flight path, etc.) } \\
\hline ng/testing activities occur & t same time as overflights? (Do the \\
\hline
\end{tabular}




\begin{tabular}{|c|c|}
\hline Activity & Fixed-wing aircraft overflight \\
\hline Function & Attack. \\
\hline Function description & $\begin{array}{l}\text { Conducts air-to-air combat and air-to-surface attack. All-weather, highly } \\
\text { maneuverable aircraft. Able to detect and track high-speed targets and } \\
\text { aircraft at beyond visual range, and can detect low-flying aircraft in radar } \\
\text { ground clutter. }\end{array}$ \\
\hline \multirow[t]{4}{*}{ Types and characteristics of aircraft } & $\begin{array}{l}\text { F-15 Eagle } \mathrm{C} \text { and } \mathrm{D} \text { models: } 25,000 \mathrm{lbs} / \mathrm{engine}, 2 \text { engines, max takeoff } \\
\text { weight } 68,000 \mathrm{lbs} \text {, speed } 1,875 \mathrm{mph} \text {. }\end{array}$ \\
\hline & $\begin{array}{l}\text { F-16 Fighting Falcon C and D models: } 27,000 \mathrm{lbs}, 1 \text { engine, max takeoff } \\
\text { weight } 37,500 \mathrm{lbs} \text {, speed } 1,500 \mathrm{mph} \text {. }\end{array}$ \\
\hline & $\begin{array}{l}\text { F-117A Nighthawk: Thrust was not specifically listed, has } 2 \text { GE F404 } \\
\text { engines, max takeoff weight was not listed, speed--high subsonic. }\end{array}$ \\
\hline & $\begin{array}{l}\text { Training for F-15E and F-16 pilots begins with low-altitude tactical } \\
\text { navigation training and low-altitude step down training. Low-altitude step } \\
\text { down training in the certification process for pilots to become adept at } \\
\text { operating safely at low altitude. Pilots must learn to navigate at low- } \\
\text { altitude while maintaining tactical formation to maximize self-defense } \\
\text { capabilities. Hard turns, climbs, and dives need to be practiced frequently } \\
\text { to maintain maneuvering proficiency. Low-altitude step down training } \\
\text { begins at approximately } 2,000 \mathrm{ft} \text {. AGL, and pilots must demonstrate } \\
\text { proficiency at each altitude before descending to a lower altitude. Typical } \\
\text { training altitudes are } 2,000,1,500,500 \text {, and } 300 \mathrm{ft} \text { AGL. Military Training } \\
\text { Routes (MTRs) are an excellent vehicle for initial training, but as } \\
\text { formations get larger and training scenarios more complex, the restrictions } \\
\text { placed on flight along MTRs limits training potential. }\end{array}$ \\
\hline Low-altitude range for this function & $\begin{array}{l}\text { Low-altitude tactical navigation: Navigation by reference to ground } \\
\text { features and onboard navigation equipment, at high speeds and low altitude, } \\
\text { is difficult because of the limited ability to see terrain features beyond a } \\
\text { short distance from the line of flight. Navigation at low altitude and high } \\
\text { speed requires regular practice to maintain proficiency, increase situational } \\
\text { awareness, and avoid task saturation. Where training allows, pilots also } \\
\text { practice terrain masking, attempting to hide the aircraft from simulated } \\
\text { enemy radar. Night navigation training is also accomplished under } \\
\text { simulated or actual low visibility conditions with the use of onboard } \\
\text { sensors such as ground mapping radar, terrain following radar, and infrared } \\
\text { or low light television sensors that provide reference to ground features. } \\
\text { Military Training Routes designed for either visual or instrument } \\
\text { conditions are the primary airspace used for initial tactical navigation } \\
\text { training, but MOAs (Military Operations Areas) are an alternative. }\end{array}$ \\
\hline $\begin{array}{l}\text { Typical flight patterns for this } \\
\text { function }\end{array}$ & $\begin{array}{l}\text { F-15 Eagle and F-16 Fighting Falcon are extremely maneuverable, possibly } \\
\text { indicating that their flight path may be back and forth. No description is } \\
\text { given for the flight path of the F-117A Nighthawk. }\end{array}$ \\
\hline $\begin{array}{l}\text { Frequency of overflight pattern } \\
\text { during typical exercise }\end{array}$ & Specific to aircraft and exercise. \\
\hline $\begin{array}{l}\text { Area of overflight during typical } \\
\text { exercise }\end{array}$ & $\begin{array}{l}\text { Due to their high speed potential, it is assumed that the area of overflight } \\
\text { would be quite large. }\end{array}$ \\
\hline $\begin{array}{l}\text { Duration of overflight during typical } \\
\text { exercise }\end{array}$ & $\begin{array}{l}\text { Per p. } 2-8 \text { of the Pacific Missile Range Facility (PMRF) Enhanced } \\
\text { Capability Final EIS, duration of the air combat maneuver exercise } \\
\text { (ACMEX) is usually } 45 \text { minutes. }\end{array}$ \\
\hline $\begin{array}{l}\text { Number of takeoffs / landings during } \\
\text { typical exercise }\end{array}$ & Not determined. \\
\hline $\begin{array}{l}\text { Size of typical squadron engaging in } \\
\text { this function }\end{array}$ & $\begin{array}{l}\text { Per p. } 2-8 \text { of the Pacific Missile Range Facility (PMRF) Enhanced } \\
\text { Capability Final EIS, the air combat maneuver exercise (ACMEX) involves }\end{array}$ \\
\hline
\end{tabular}


2 or more (generally 2-4) fighter aircraft.

Time of day / seasonal / weather Generally no constraints.

constraints

Stressors

Noise and vibration during takeoff, overflight and landing.

\section{SITE-SPECIFIC AND ASSESSMENT-SPECIFIC QUESTIONS:}

New training activity or change in an old one (e.g., more aircraft, different flight path, etc.)

Any training/testing activities occur at same time as overflights? (Do these produce loud sound?)

Which training activities occur on land below/near overflight routes?

Activity

Function

Function description

Types and characteristics of aircraft

Thes and characteristics of aircraft

MH-53J Pave Low IIIE: 4,330 horsepower/engine, 2 engines, max takeoff weight 46,000 lbs, emergency war plan allows for 50,000 lbs, speed 165 mph.

Low-altitude range for this function Since these are helicopters, assume that they generally fly at low altitudes. Typical flight patterns for this function When MH-60G Pave Hawk performs combat search and rescue, assume that the flight path is back and forth; otherwise, generally a straight line.

Frequency of overflight pattern during Not determined.

typical exercise

Area of overflight during typical Not determined.

exercise

Duration of overflight during typical Not determined.

exercise

Number of takeoffs / landings during Not determined.

typical exercise

Size of typical squadron engaging in Per the Fallon, NV Final EIS, p. ES-4, regarding integrated air and ground this function

training activities, a typical ground training portion of the exercise associated with the four to six air wing training events will consist of up to two vehicles, up to two helicopters, and up to six personnel (not including two to four opposition forces--p. 2-26). Per p. 2-25, combat search and rescue training integrates air operations with the rescue of downed pilots; this training takes place during the four to six air wing events that occur each year. Components of this training include locating, authenticating, and retrieving the downed personnel and avoiding opposition forces. The ground component of this training includes driving out and dropping off the downed pilot and bringing in a helicopter and rescuing the pilot. On some events, an opposition force of two to four personnel are used to try and capture the downed pilot. Per p. 2-26, desert rescue training is similar to combat search and rescue but is a joint exercise

Time of day / seasonal / weather Can generally fly in all weather conditions.

constraints

Stressors

Noise and vibration during takeoff, overflight, and landing.

New training activity or change in an old one (e.g., more aircraft, different flight path, etc.)

Any training/testing activities occur at same time as overflights? (Do these produce loud sound?) 
Which training activities occur on land below/near overflight routes? 